\title{
Detrital Zircons U-Pb Age and Hf Isotope from the Western Side of the Taiwan Strait: Implications for Sediment Provenance and Crustal Evolution of the Northeast Cathaysia Block
}

\author{
Yonghang $\mathrm{Xu}^{1, *}$, Qinqin Sun ${ }^{2}$, Liang $\mathrm{Yi}^{3}$, Xijie Yin ${ }^{1}$, Aijun Wang ${ }^{1}$, Yunhai $\mathrm{Li}^{1}$, and Jian $\mathrm{Chen}^{1}$ \\ ${ }^{1}$ Open Laboratory of Ocean and Coast Environmental Geology, Third Institute of \\ Oceanography State Oceanic Administration, Xiamen, China \\ ${ }^{2}$ Fujian Provincial Key Laboratory of Coast and Island Management Technology Study, \\ Fujian Institute of Oceanography, Xiamen, China \\ ${ }^{3}$ State Key Laboratory of Lithospheric Evolution, Institute of Geology and Geophysics, \\ Chinese Academy of Sciences, Beijing, China
}

Received 18 December 2012, revised 8 February 2014, accepted 18 February 2014

\begin{abstract}
In situ detrital zircons $\mathrm{U}-\mathrm{Pb}$ and $\mathrm{Hf}$ isotope analyses from the Min and Jiulong River of Southeast China were carried out to identify sediment provenance and crustal evolution of the northeast Cathaysia Block. Detrital zircons from both rivers displayed similar spectrum peaks at 236, 155, and $110 \mathrm{Ma}$, but samples from the Min River displayed a distinct Caledonian peak (ca. $460 \mathrm{Ma}$ ) and contained more Precambrian particles (ca. $1.8 \mathrm{Ga}$ ), which likely stemmed from the upstream area of the Wuyishan terrain. Interestingly, because Taiwan Island cannot supply Caledonian and Paleoproterozoic detrital materials and because the Ou and Jiulong River also lack components from these two populations, it is highly likely that the sediment in the western Taiwan coast partially originates from the Min River. The sediments from the Min River in Fujian are also considered the most likely source of the beach sands of western Taiwan (Chen et al. 2006). However, we stress that the $\sim 1.8 \mathrm{Ga}$ age source in the western Taiwan sediments was found and recognized. Combining U-Pb dating and Hf-isotope suggests that the northeast Cathaysia Block contains some Neoarchean detrital zircons, which derived from the incorporation of juvenile mantle materials and re-melting of ancient crustal substances. The wide ranges of $\varepsilon_{\mathrm{Hf}}(\mathrm{t})$ value in the Paleoproterozoic and Neoproterozoic demonstrate the re-melting of ancient crustal materials with minor juvenile mantle materials. Phanerozoic zircons stemmed from re-melting and recycling of Proterozoic crustal materials with or without the invasion of juvenile mantle-derived magmas.
\end{abstract}

Key words: Detrital zircon, U-Pb age, Hf isotope, Provenance, Crustal evolution, Cathaysia Block

Citation: Xu, Y., O. Sun, L. Yi, X. Yin, A. Wang, Y. Li, and J. Chen, 2014: Detrital zircons U-Pb age and Hf isotope from the western side of the Taiwan Strait: Implications for sediment provenance and crustal evolution of the northeast Cathaysia Block. Terr. Atmos. Ocean. Sci., 25, 505-535, doi: 10.3319/ TAO.2014.02.18.01(TT)

\section{INTRODUCTION}

The Taiwan Strait connects the East China Sea and South China Sea, which are two major marginal seas of the western Pacific. This region serves as a canonical area in investigating terrigenous detrital materials transported into the sea, including the provenance and flux, as well as their distribution, transport and dispersion in continental shelves (Liu et al. 2002; Dadson et al. 2003; Xu et al. 2009). Detrital sediments from exposed continental crust across drainage basins may provide a record of the paleogeographic setting

\footnotetext{
* Corresponding author

E-mail: yonghang_xu@163.com
}

and their surrounding source regions (Cawood et al. 2003; Veevers et al. 2005).

Detrital zircons are resistant to chemical weathering and mechanical abrasion, and thus survive weathering from their provenance and subsequent transportation in fluvial systems. Therefore, in situ zircon U-Pb dating and Hf-isotope analysis has proven to be a useful tool in assessing the distribution of source rocks in the provenance and reconstructing tectonic evolution of continental blocks (Condie et al. 2005; Iizuka et al. 2005; Veevers et al. 2005; Yang et al. 2009; Wang et al. 2011).

Chen et al. (2006) proposed that sediments from the 
Min River in Fujian, Southeast China, are considered the most likely source of the beach sands of W Taiwan. However, ca. 1.8 Ga monazites have not been discovered in the Min River estuary and Wuyishan area (Chen et al. 2006, 2008). The Min River and Jiulong River are the major waterways flowing into the Taiwan Strait from the west and supply the strait with large amounts of terrigenous detrital materials (Xu 1994; Liu et al. 2001). In this study, we present $\mathrm{U}-\mathrm{Pb}$ and $\mathrm{Hf}$-isotope analyses of detrital zircons from the Min and Jiulong Rivers. The isotopic data are used to decipher identify sediment provenance and reveal the crustal evolution of the northeast Cathaysia Block.

\section{GENERAL GEOLOGY OF THE DRAINAGE BASINS}

The South China continent is composed of the Yangtze Block in the northwest and the Cathaysia Block in the southeast, along the Jiangshao-Pingyu Fault (Fig. 1a). The Min River flows across northern Fujian (Fig. 1b). As the largest river in the province it has a drainage basin area of $61000 \mathrm{~km}^{2}$, an average flow of $1750 \mathrm{~m}^{3} \mathrm{~s}^{-1}$ and annual average sediment loads of $715.5 \times 10^{4} \mathrm{t}$ (Liu et al. 2001). The Jiulong River is situated in southern Fujian and is the second largest river in the province. The river has a drainage basin area of $14700 \mathrm{~km}^{2}$ and annual average sediment loads of $223 \times 10^{4} \mathrm{t}$ (Xu 1994). Because both drainage basins are mainly characterised by mountains and hills and concentrat- ed rainfall, large quantities of terrigenous detrital materials are expected to be transported into the Taiwan Strait.

Precambrian basement rocks in the Cathaysia Block are sparsely exposed in the Chen Cai, Badu, Wuyishan, Nanling, Yunkai and Hainan areas (Zhao and Cawood 2012). The Min River originates from the Wuyishan region, which is a major Precambrian outcropping area of the Cathaysia Block (Fig. 1b). The headstream of the Jiulong River is located in the Longyan region (eastern Nanling). The Cathaysia Block has no exposed Archean rocks, but numerous Archean detrital zircons and minor inherited or xenocrystic zircons, implying the existence of Archean crust underlying the block or adjacent regions (Wan et al. 2007; Yu et al. 2009, 2012). The Cathaysia Block basement is composed mainly of Neoproterozoic basement rocks $(\sim 90 \%)$ with a minor outcrop of Paleoproterozoic rocks (Badu Group) in Wuyishan, and Mesoproterozoic rocks (Baoban, Shilu Group) in Hainan Island (Yu et al. 2010; Zhao and Cawood 2012). This composition is exemplified by ancient rock outcrops, which have been dated to approximately $1.8 \mathrm{Ga}$, in the Badu Group of southwestern Zhejiang and northwestern Fujian (Li et al. 1998; Yu et al. 2009, 2012). The Cathaysia Block has been bear strong overprinting of middle Paleozoic (Caledonian), Triassic (Indosinian) and Jurassic-Cretaceous (Yanshanian) (Chen and Jahn 1998; Zhou 2003; Wang et al. 2013). Early Palaeozoic granites are widespread in the eastern South China Block. Late Mesozoic granites from the Jurassic to Cretaceous display a migratory pattern from inland to coast (a)

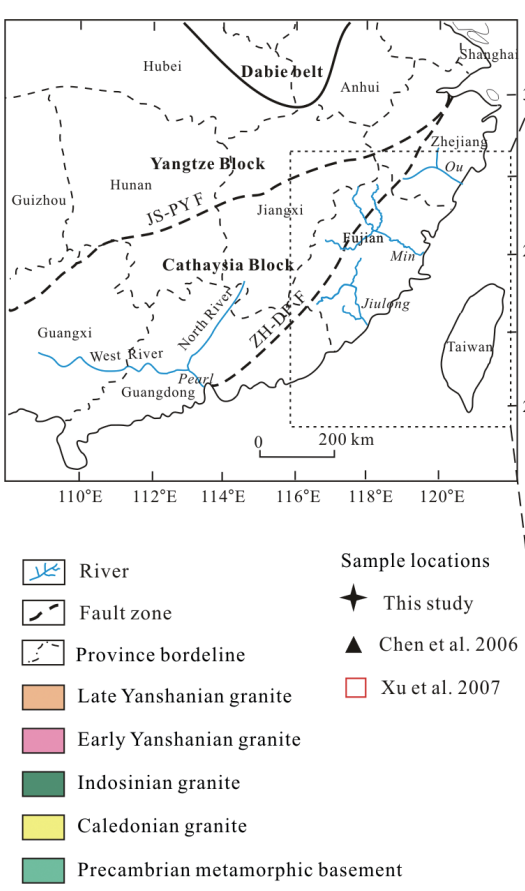

(b)

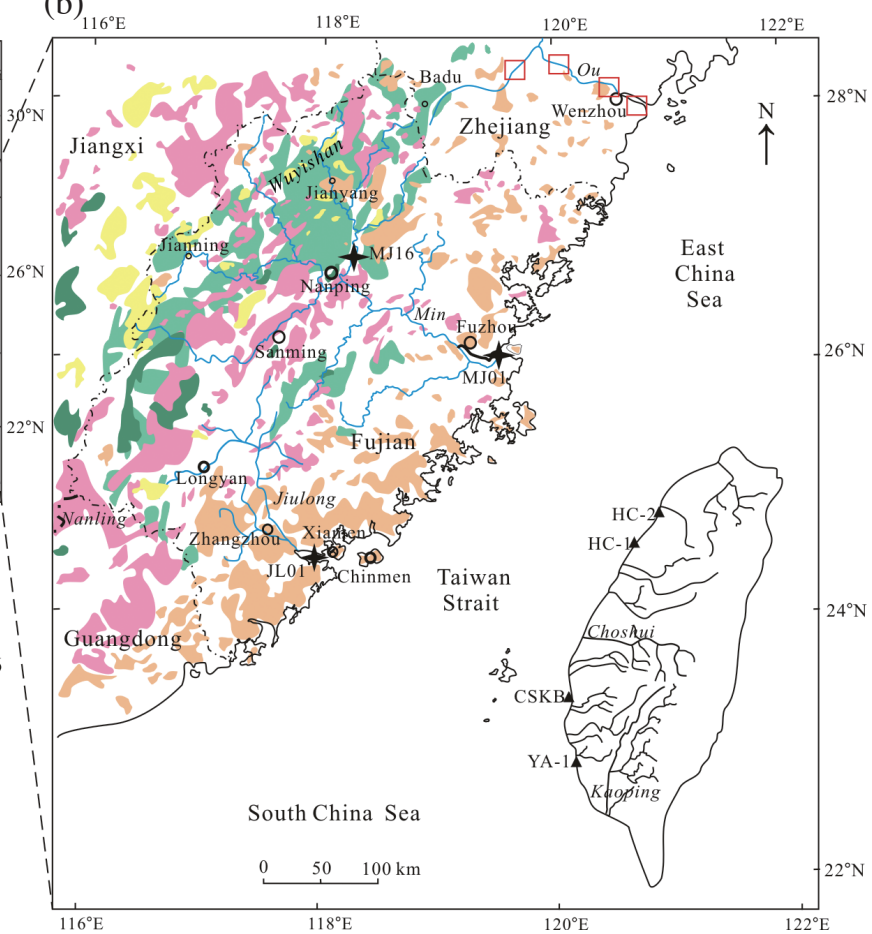

Fig. 1. Simplified map of major tectonic units in the South China (a) and geological map of the drainage basins of the Min River and Jiulong River in Fujian Province (b) revised from Sun (2006) .Abbreviation: JS-PY F, Jiangshao-Pingyu Fault; ZH-DP F, Zhenghe-Dapu Fault. 
(Zhou et al. 2006; Li and Li 2007; Xu 2008; Wang et al. 2013). The drainage basins of both rivers are approximately perpendicular to the orientation of the Cathaysia granitevolcanic belts flowing into the Taiwan Strait (Fig. 1b).

\section{SAMPLE AND ANALYSIS}

Two surface sediment samples were collected from the Min River and one from Jiulong River (Fig. 1b). Three samples were all dominated by medium-coarse-grained feldspars and quartz sand. After washing, magnetic sorting and heavy liquid separation, zircon grains were glued to one side of double-sided tape and mounted with epoxy resin to form targets. The cathodoluminesence (CL) emission images have been widely used to distinguish igneous zircons from metamorphic zircons. In order to investigate the internal structures of zircon particles, zircon CL imaging was taken using a scanning electron microprobe at the Guangzhou Institute of Geochemistry, Chinese Academy of Sciences.

An Agilent 7500a quadruple (Q)-ICPMS and a Neptune multi-collector (MC) -ICPMS were used for simultaneous determination of zircon $\mathrm{U}-\mathrm{Pb}$ age, trace elements and Lu-Hf isotopes with a $193 \mathrm{~nm}$ excimer ArF laser-ablation system (GeoLas Plus) attached. Experiments were carried out at the MC-ICPMS laboratory of the Institute of Geology and Geophysics, Chinese Academy of Sciences. The analytic methods and equipment parameters were similar to those of Xie et al. (2008).

The spot size of laser ablation was $44 \mu \mathrm{m}$ in diameter. $\mathrm{U}$, Th and $\mathrm{Pb}$ concentrations were calibrated using ${ }^{29} \mathrm{Si}$ as an internal standard and NIST 610 as the reference standard (Pearce et al. 1997). ${ }^{207} \mathrm{~Pb} /{ }^{206} \mathrm{~Pb},{ }^{206} \mathrm{~Pb} /{ }^{238} \mathrm{U},{ }^{207} \mathrm{~Pb} /{ }^{235} \mathrm{U}$ $\left.{ }^{235} \mathrm{U}={ }^{238} \mathrm{U} / 137.88\right)$ ratios were corrected using the $91500 \mathrm{ex}-$ ternal standard. GJ-1 and 91500 yielded weighted ${ }^{206} \mathrm{~Pb} /{ }^{238} \mathrm{U}$ ages of $603 \pm 8$ and $1063 \pm 17 \mathrm{Ma}$, respectively. The fractionation correction and results were calculated using GLITTER 4.0 (Jackson et al. 2004). Subsequently, common Pb was corrected according to the method proposed by Andersen (2002). The weighted mean U-Pb ages and concordia plots were processed using ISOPLOT 3.0 (Ludwig 2003).

In situ determination of zircon Lu-Hf isotopes was performed using a Neptune MC-ICPMS, which used a Geolas $193 \mathrm{ArF}$ laser ablation system. In this study, the mean ${ }^{173} \mathrm{Yb} /{ }^{171} \mathrm{Yb}$ ratio of the individual spot is used to calculate the fractionation coefficient $\left(\beta_{\mathrm{Yb}}\right)$, and then derive the contribution of ${ }^{176} \mathrm{Yb}$ to ${ }^{176} \mathrm{Hf}$ (Iizuka et al. 2005). Detailed test procedures and equipment operating conditions were previously described (Wu et al. 2006). Interference corrections were facilitated using ${ }^{175} \mathrm{Lu} /{ }^{176} \mathrm{Lu}=0.02655$ and ${ }^{176} \mathrm{Yb} /{ }^{172} \mathrm{Yb}=0.5887$ (Wu et al. 2007). The ${ }^{176} \mathrm{Lu}$ decay constant required for the calculation of $\varepsilon_{\mathrm{Hf}}(\mathrm{t})$ was $1.867 \times 10^{-11} \mathrm{y}^{-1}$ (Söderlund et al. 2004). The ${ }^{176} \mathrm{Hf} /{ }^{177} \mathrm{Hf}$ and ${ }^{176} \mathrm{Lu} /{ }^{177} \mathrm{Hf}$ ratios of chondrite at the present day are 0.282785 and 0.0336 , respectively (Bouvier et al. 2008). To calculate model ages based on a depleted-mantle source, we have adopted a model with ${ }^{176} \mathrm{Hf} /{ }^{177} \mathrm{Hf}=0.28325$ (Griffin et al. 2002) and ${ }^{176} \mathrm{Lu} /{ }^{177} \mathrm{Hf}$ ratio of 0.0384 (Griffin et al. 2000). GJ-1 and Mud Tank zircons give weighted ${ }^{176} \mathrm{Hf} /{ }^{177} \mathrm{Hf}$ ratios of $0.282009 \pm 20(2 \sigma)$ and $0.282504 \pm 15(2 \sigma)$, respectively. Hf isotopic composition is calculated using the following equations:

$$
\begin{aligned}
& \varepsilon_{\mathrm{Hf}}(0)=\left[\left({ }^{176} \mathrm{Hf} /{ }^{177} \mathrm{Hf}\right)_{\mathrm{S}} /\left({ }^{176} \mathrm{Hf} /{ }^{177} \mathrm{Hf}\right)_{\mathrm{CHUR}, 0}-1\right] \times 10000 \\
& \varepsilon_{\mathrm{Hf}}(\mathrm{t})=\left\{\left[\left({ }^{176} \mathrm{Hf} /{ }^{177} \mathrm{Hf}\right)_{\mathrm{S}}-\left({ }^{176} \mathrm{Lu} /{ }^{177} \mathrm{Hf}\right)_{\mathrm{S}} \times\left(\mathrm{e}^{\lambda \mathrm{t}}-1\right)\right] /\right.
\end{aligned}
$$

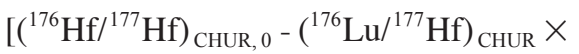

$$
\begin{aligned}
& \left.\left.\left(\mathrm{e}^{\lambda \mathrm{t}}-1\right)\right]-1\right\} \times 10000 \\
& \mathrm{~T}_{\mathrm{DM}}=1 / \lambda \times \ln \left\{1+\left[\left({ }^{176} \mathrm{Hf} /{ }^{177} \mathrm{Hf}\right)_{\mathrm{S}}-\left({ }^{176} \mathrm{Hf} /{ }^{177} \mathrm{Hf}\right)_{\mathrm{DM}}\right] /\right. \\
& \left.\left[\left({ }^{176} \mathrm{Lu} /{ }^{177} \mathrm{Hf}\right)_{\mathrm{S}}-\left({ }^{176} \mathrm{Lu} /{ }^{177} \mathrm{Hf}\right)_{\mathrm{DM}}\right]\right\} \\
& \mathrm{T}_{\mathrm{DM} 2}=\mathrm{T}_{\mathrm{DM}}-\left(\mathrm{T}_{\mathrm{DM}}-\mathrm{t}\right) \times\left[\left(\mathrm{f}_{\mathrm{CC}}-\mathrm{f}_{\mathrm{S}}\right) /\left(\mathrm{f}_{\mathrm{CC}}-\mathrm{f}_{\mathrm{DM}}\right)\right] \\
& \mathrm{f}_{\mathrm{Lu} / \mathrm{Hf}}=\left({ }^{176} \mathrm{Lu} /{ }^{177} \mathrm{Hf}\right)_{\mathrm{S}} /\left({ }^{176} \mathrm{Lu} /{ }^{177} \mathrm{Hf}\right)_{\mathrm{CHUR}}-1
\end{aligned}
$$

\section{RESULTS}

Detrital zircons are characterized by euhedral, short prismatic shapes, with oscillatory bands in the CL images (Fig. 2). A few zircons display unzoned or cloudy-zoned CL image patterns. Most zircons had $\mathrm{Th} / \mathrm{U}$ ratios greater than 0.10 (only five particles $\mathrm{Th} / \mathrm{U}$ ratios less than 0.10 ). More than 60 zircons were conducted for each sample to satisfy statistical requirements (Vermeesch 2004; Andersen 2005).

\subsection{U-Pb Ages Results}

We used ${ }^{207} \mathrm{~Pb} / 206 \mathrm{~Pb}$ ages for zircons of age $\geq 1.0 \mathrm{Ga}$ and ${ }^{206} \mathrm{~Pb} /{ }^{238} \mathrm{U}$ ages for zircons of age $<1.0 \mathrm{Ga}$ (Compston et al. 1992). It is worth noting that only analyses with less than $10 \%$ discordance were included in the following discussion.

\subsubsection{Min River (MJ01)}

A total of 146 analyses of 146 grains from the Min River estuary were made, of which 126 analyses are concordant with ages ranging from $2765 \pm 12$ to $97 \pm 2 \mathrm{Ma}$ (Appendix 1). The age distributions of detrital zircon exhibited four major groups (Figs. 3a and b): $1.6-1.9 \mathrm{Ga}$ (16.7\%), 351 - $498 \mathrm{Ma}(27.8 \%), 224$ - $259 \mathrm{Ma}(7.9 \%)$, and 97 - $182 \mathrm{Ma}(27.8 \%)$. In addition, two zircon grains with magmatic internal zoning structures show Neoarchean ages of $2506 \pm 10$ and $2765 \pm 12 \mathrm{Ma}$, and nine detrital zircons belong to the Neoproterozoic (613 - $919 \mathrm{Ma})$.

\subsubsection{Min River (MJ16)}

A total of 97 analyses of 97 grains from the upstream Min River were undertaken, of which 10 analyses were 


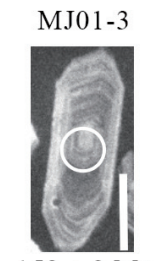

$158 \pm 2 \mathrm{Ma}$

MJ16-6

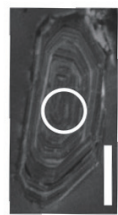

$163 \pm 3 \mathrm{Ma}$
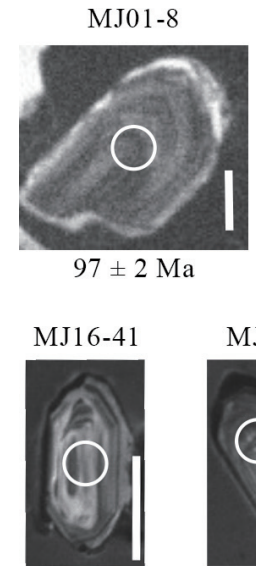

$222 \pm 9 \mathrm{Ma}$

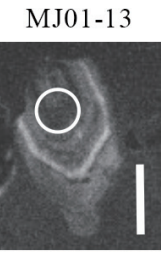

$243 \pm 3 \mathrm{Ma}$

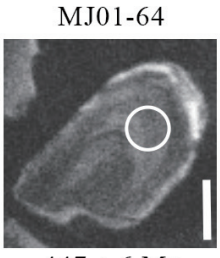

$447 \pm 6 \mathrm{M}$

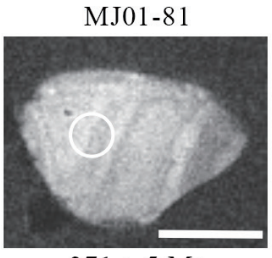

$371 \pm 5 \mathrm{Ma}$

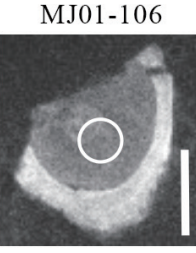

$1715 \pm 10 \mathrm{Ma}$
MJ01-119

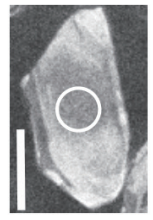

$2356 \pm 9 \mathrm{Ma}$

MJ16-97

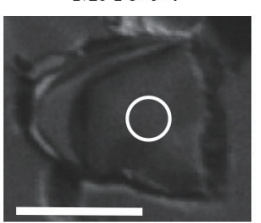

$2067 \pm 11 \mathrm{Ma}$

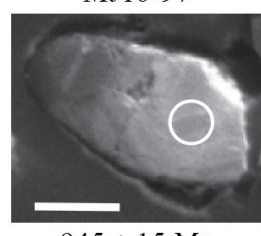

$945 \pm 15 \mathrm{Ma}$

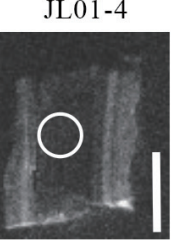

$116 \pm 1 \mathrm{Ma}$
JL01-15

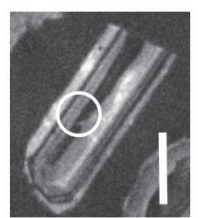

$155 \pm 2 \mathrm{Ma}$
JL01-25

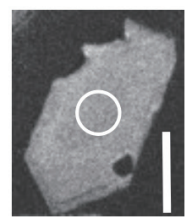

$1588 \pm 10 \mathrm{Ma}$

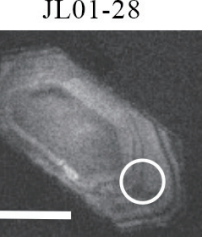

$251 \pm 3 \mathrm{Ma}$
JL01-43

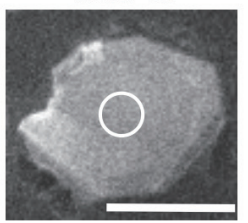

$2241 \pm 9 \mathrm{Ma}$
JL01-59

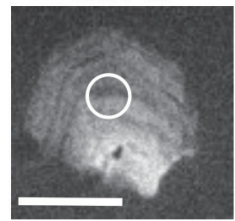

$164 \pm 5 \mathrm{Ma}$

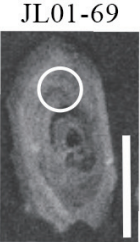

$403 \pm 8 \mathrm{Ma}$

Fig. 2. Cathodoluminescence images of representative zircons (scale bar $=100 \mu \mathrm{m})$. Circles $(44 \mu \mathrm{m})$ show U-Pb age analytical sites.
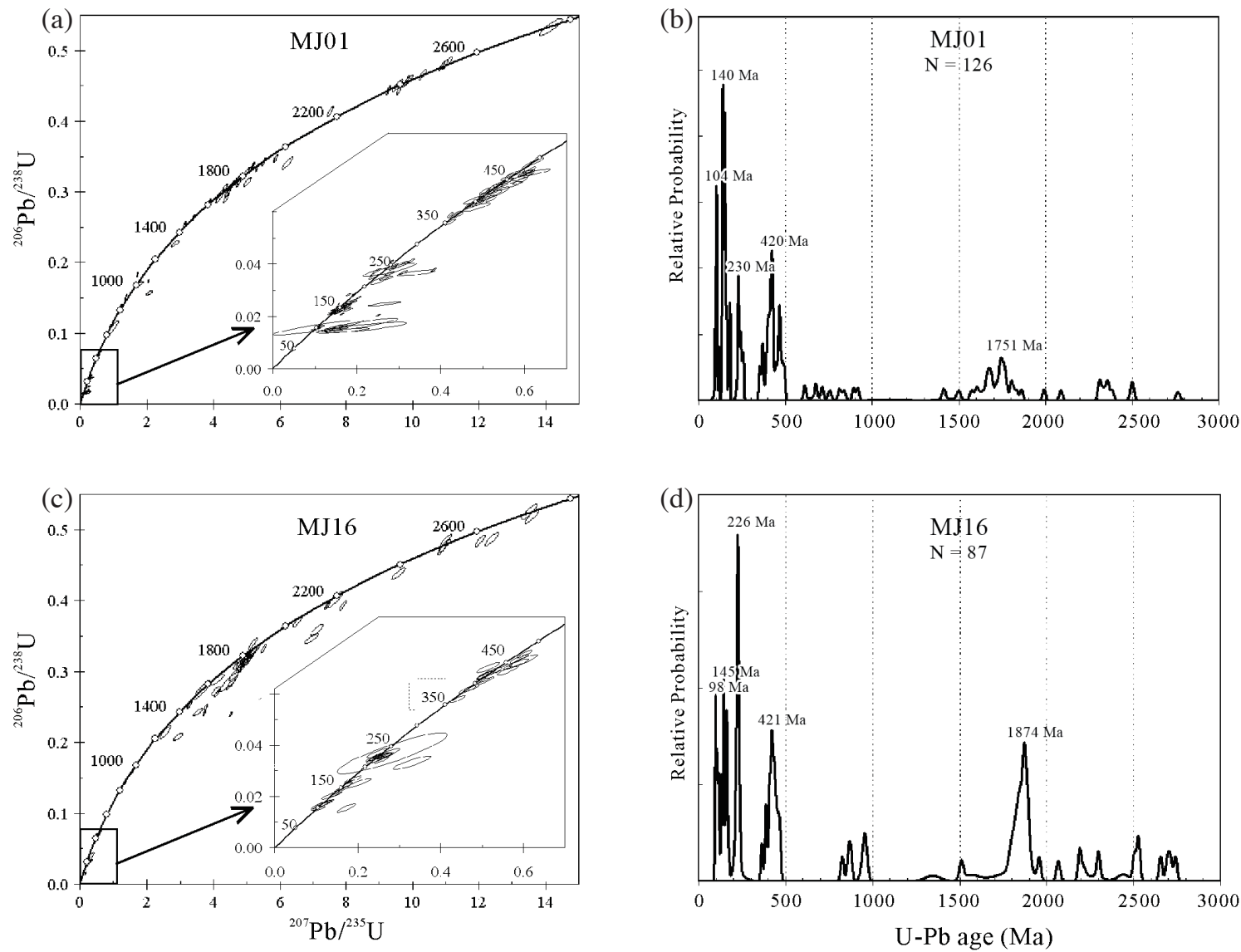

Fig. 3. Left panels show U-Pb concordia plots (a, c, e) of the detrital zircons from the Min River (MJ01 and MJ16) and Jiulong River (JL01). Insets show expanded plots for younger zircons. Right panels show corresponding relative probability plots of $\mathrm{U}-\mathrm{Pb}$ ages for concordant detrital zircons (b, $\mathrm{d}, \mathrm{f}$ ). 

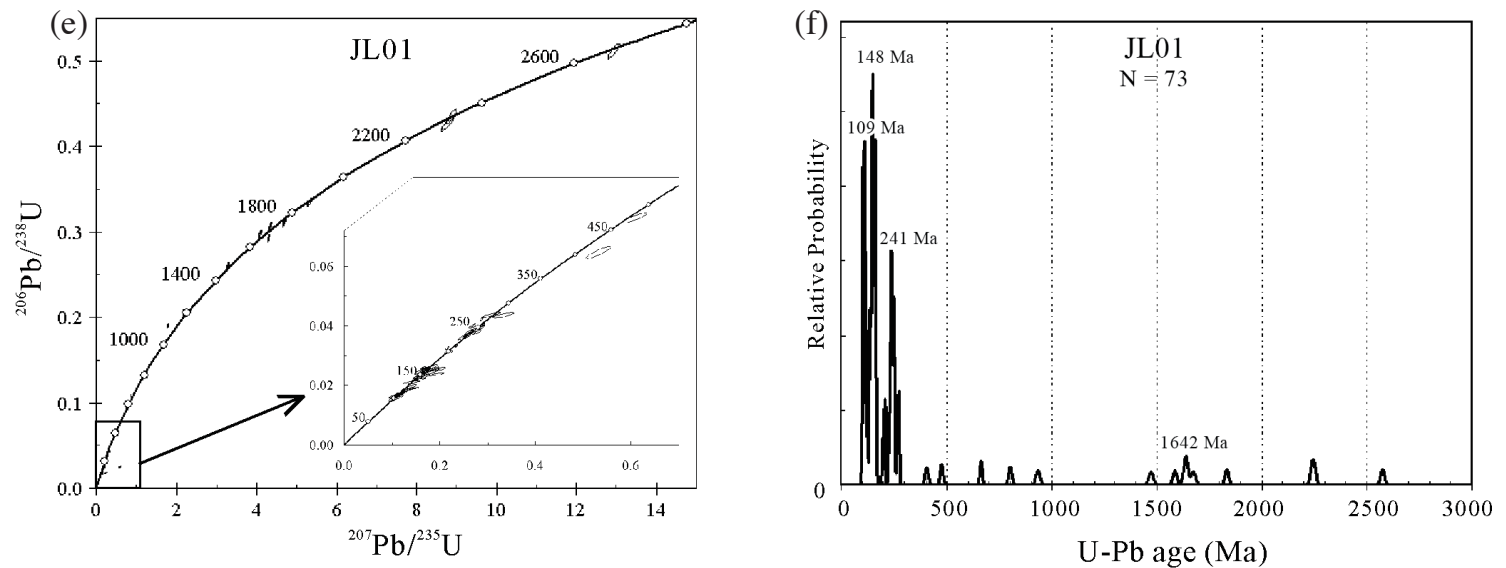

Fig. 3. (Continued)

discordant. The concordant zircons ranged in age from $2742 \pm 9$ to $97 \pm 2 \mathrm{Ma}$ (Appendix 1), and exhibited four major populations 1.6 - $1.9 \mathrm{Ga}(24.1 \%), 363$ - $469 \mathrm{Ma}(18.4 \%)$, 210 - $233 \mathrm{Ma}(13.8 \%)$ and 97 - $170 \mathrm{Ma}(17.2 \%)$ (Figs. 3c and d). Seven zircon grains yielded the oldest ${ }^{207} \mathrm{~Pb} /{ }^{206} \mathrm{~Pb}$ ages of $2504-2742 \mathrm{Ma}(8.0 \%)$. Six detrital zircons belong to the Neoproterozoic (826- $964 \mathrm{Ma})$.

\subsubsection{Jiulong River (JL01)}

A total of 80 analyses of 80 grains from the Jiulong River estuary were undertaken, of which 73 analyses were concordant. The concordant zircons ranged in age from $2577 \pm 9$ to $101 \pm 4 \mathrm{Ma}$ (Appendix 1). Two major groups can be identified (Figs. 3e and f): $101-197 \mathrm{Ma}(56.2 \%)$ and 207 - $254 \mathrm{Ma}(20.5 \%)$. The third largest age population was made up of 5 grains with a range of $1474-1675$ Ma. Few Caledonian and Paleoproterozoic zircons have been discovered in Jiulong River estuary.

\subsection{Zircon Hf Isotopic Results}

Almost all of the zircons had ${ }^{176} \mathrm{Lu} /{ }^{177} \mathrm{Hf}$ ratios of less than 0.002 , indicating that the zircons had a minimal extent of radioactive $\mathrm{Hf}$ accumulation after their formation. Hence, the present-day ${ }^{176} \mathrm{Hf} /{ }^{177} \mathrm{Hf}$ ratios of the zircons are representative of the ${ }^{176} \mathrm{Hf} /{ }^{177} \mathrm{Hf}$ ratios upon formation of the zircons (Amelin et al. 1999). The analytical results are summarized in Appendix 2.

Detrital zircons from the Min River showed a large variation in $\mathrm{Hf}$ isotopic compositions (0.280856 - 0.282816$)$, with $\varepsilon_{\mathrm{Hf}}(\mathrm{t})$ values varying from +11.5 to -21.1 (Fig. $4 \mathrm{a}$ ). Min River zircons chiefly fall in the negative epsilon space, but only 24 zircons $(11 \%)$ with positive $\varepsilon_{\mathrm{Hf}}(\mathrm{t})$. Figure $4 \mathrm{~b}$ shows the distributions of the two-stage $\mathrm{Hf}\left(\mathrm{T}_{\mathrm{DM} 2}\right)$ model ages. It can be seen that the crustal model age shows two prominent groups of $3.2-2.6$ and $2.0-1.4 \mathrm{Ga}$ from the two samples in Min River.

Detrital zircons from the Jiulong River estuary had ${ }^{176} \mathrm{Hf} /{ }^{177} \mathrm{Hf}$ ratios in the range of $0.280902-0.282842$. The majority of particles had ratios greater than 0.282010 , corresponding to an age range of $101-800 \mathrm{Ma}$ and $\varepsilon_{\mathrm{Hf}}(\mathrm{t})$ values between -12.7 and +6.1 (Fig. 4c). A few zircons had ratios less than 0.282010 , corresponding to an age range of 932 - $2577 \mathrm{Ma}$ and $\varepsilon_{\mathrm{Hf}}(\mathrm{t})$ values between -5.5 and -15.8 . The Jiulong River also shows a large abundance of negative and some positive $\varepsilon_{\mathrm{Hf}}(\mathrm{t})$ values of 275 - $100 \mathrm{Ma}$ (Fig. 4c). Zircons from the Jiulong River show a significant number of zircons with $\mathrm{T}_{\mathrm{DM} 2}$ between 1.2 and $1.8 \mathrm{Ga}$ (Fig. $4 \mathrm{~d}$ ).

\section{DISCUSSION}

\subsection{Provenance Tracing}

$\mathrm{U}-\mathrm{Pb}$ age analysis revealed that the detrital zircons from the Min River contained a large proportion of Precambrian particles (37\%). In particular sample MJ16 has a clear peak age corresponding to the Paleoproterozoic (1874 Ma). This feature is related to the fact that the Badu Group with a Paleoproterozoic basement extensively outcrops in the Min River upstream basin (Li et al. 1998; Yu et al. 2009, 2012). In addition, nine Neoarchean detrital zircons are found in this study, which also have been identified in Wuyishan terrain as inherited or xenocrystic zircons (Wan et al. 2007; $\mathrm{Yu}$ et al. 2009, 2012). Recent SHRIMP U-Pb zircon dates demonstrated that northeast Cathaysia has undergone tectonothermal events in Neoproterozoic (Shu et al. 2011), which could provide Neoproterozoic material. In contrast, the Jiulong River estuary contains a sporadic number of Precambrian particles (Fig. 3f).

The Cathaysia Block was impacted by the Caledonian, Hercynian-Indosinian and Yanshanian (Jurassic-Cretaceous) orogenies (Zhou et al. 2006; Xu 2008), which are widespread in the eastern South China Block (Fig. 1b). The proportion of Phanerozoic detrital zircons in the mouth of the Min River is 
significantly higher than that ones in the upstream. The Caledonian granites are well developed throughout the Wuyishan terrain (Zhou 2003; Wan et al. 2007). Consequently, a considerable proportion (23\%) of the detrital zircons in the Min River displayed prominent Caledonian traits.

A few Hercynian-Indosinian granites are exposed in Zhenghe, Mingxi and Liancheng in Fujian Province (Sun 2006) (Fig. 1b). The monazite age (Chen et al. 2008) and the zircons U-Pb age (Xu et al. 2007; Yu et al. 2012), were recently reported using sand samples from east of Wuyishan terrain, demonstrating the presence of Indosinian materials. The Indosinian granites are also exposed in the Longyan area (Zhao et al. 2006; Guo et al. 2012; Wang et al. 2013). These areas possibly provide the source of Indosinian components to the Min River and Jiulong River. From Jurassic to Cretaceous, this granite belt migrated from inland toward the coast (Zhou et al. 2006; Xu 2008). So, both the Min and Jiulong River contain a large number of Mesozoic zircons.

The detrital sediments in the Min River estuary mainly originate from the Jurassic-Cretaceous rocks in the middlelower reaches. Those are also partially derived from the Indosinian and Caledonian components of its upstream re- gion, together with Precambrian basement material from the headstream area. In contrast, the source of the detrital sediments in the Jiulong River estuary is mainly the JurassicCretaceous rocks from the middle-lower reaches of the river, with a minor contribution from the Mesoproterozoic and Hercynian-Indosinian materials of the upstream region.

\subsection{Re-Assessing the Provenance of Sediments From Western Coastal Areas of Taiwan Island}

The Min River plays a prominent role in transport and supply of deposits to the western Taiwan, where large quantities of monazites that have been dated to ca. 1.8 Ga (Chen et al. 2006). However, Precambrian monazite has not been discovered in the Min River estuary and Wuyishan area (Chen et al. 2006, 2008). Chen et al. (2008) challenged the theory of an early Proterozoic provenance in Taiwan and suggested that coastal deposits of western Taiwan may be under the control of other river systems (e.g., the Ou River; $\mathrm{Xu}$ et al. 2007) or other orogenic belts (Sano et al. 2006).

The Taiwan crust experienced five major tectonic-thermal events (Lan et al. 2008), which occurred in the early (a)

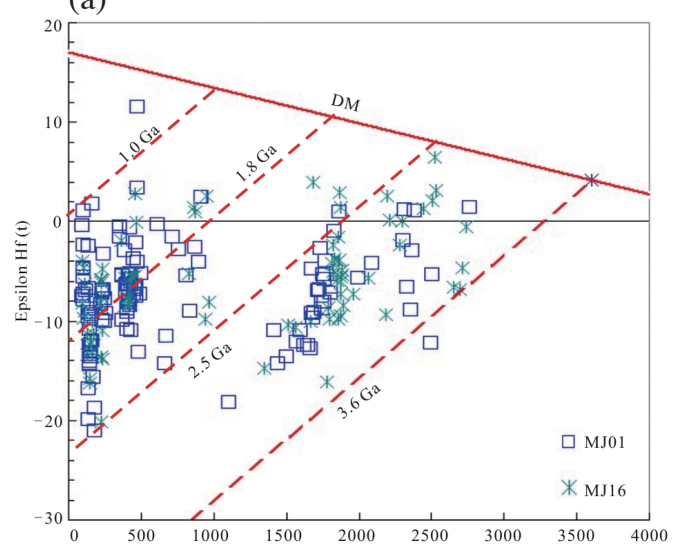

(c)

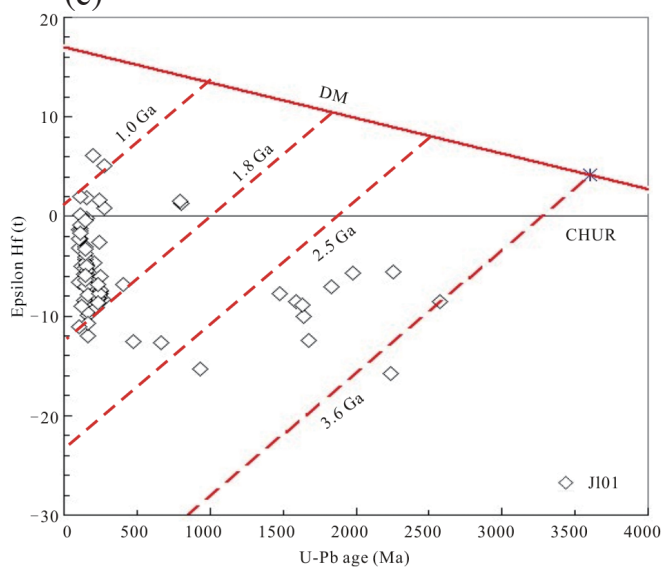

(b)

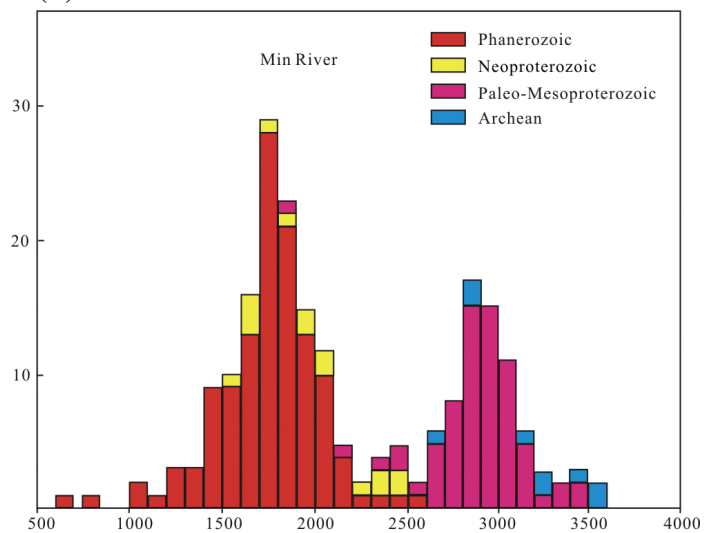

(d)

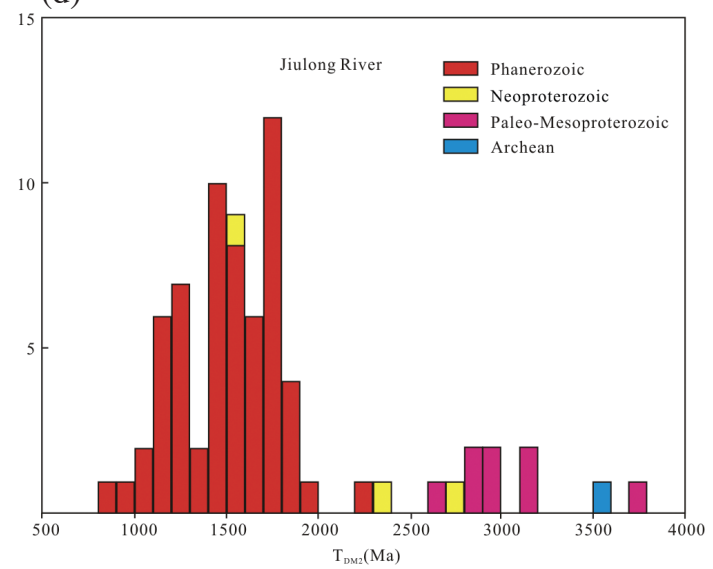

Fig. 4. Left panels show U-Pb ages versus $\varepsilon_{\mathrm{Hf}}(\mathrm{t})$ values plots of concordant zircons (a, c), right panels show histograms of the two-stage Hf model ages for the concordant zircons $(b, d)$. The intersection of these lines with the DM curve represents the crustal model age $\left(T_{\mathrm{DM} 2}\right)$ of grains lying along the line. Abbreviation: DM, Depleted Mantle; CHUR, Chondritic Uniform Reaervoir. 
Jurassic (200 - $175 \mathrm{Ma})$, late Jurassic ( 153 Ma), late Cretaceous (97 - $77 \mathrm{Ma})$ and prior to $(56-9 \mathrm{Ma})$ and after $(<5 \mathrm{Ma})$ the Pliocene, but no one in the Caledonian (360 - $540 \mathrm{Ma})$. In contrast, monazites in beaches of western Taiwan (MiaoliHsinchu area) and southern Taiwan (Chiayi-Tainan area) show prominent Caledonian (430 Ma) features (Chen et al. 2006), suggesting that these materials are unlikely to have originated from the island of Taiwan.

Further constraints on provenance can be gained by various potential sources (Fig. 5). The Paleoproterozoic peak at $\sim 1.8 \mathrm{Ga}$ is ubiquitous in the Yangtze, Ou River and Min River (Figs. 5a, b, and c), but the $2.5 \mathrm{Ga}$ and $700-900 \mathrm{Ma}$ peaks are unique to the Yangtze (Yang et al. 2012). Neoproterozoic was an important period for the crust of the South
China Block accretion and reworking (Li et al. 1995, 2002; Wang et al. 2007). However, a 420 Ma population appears to be distinctive of the Min River (Fig. 5c). Not surprisingly, the Yangtze clay mineral $(<2 \mu \mathrm{m})$ can be transported southward to Taiwan Strait by the China Coastal Current (Xu et al. 2009), but heavy minerals (i.e., monazite, zircon) to western Taiwan Island are limited. Zircons from the Ou River show the Paleoproterozoic and Cretaceous ages (Fig. 5b), but very few grains of the Paleoproterozoic and Caledonian were found in its estuary (Xu et al. 2007).

Our work broadly supports Chen et al. (2008), showing that the main sources of Taiwan sediment came from the Min River. According to Fig. 5, higher age probability and more populations of the Min River grains are centred

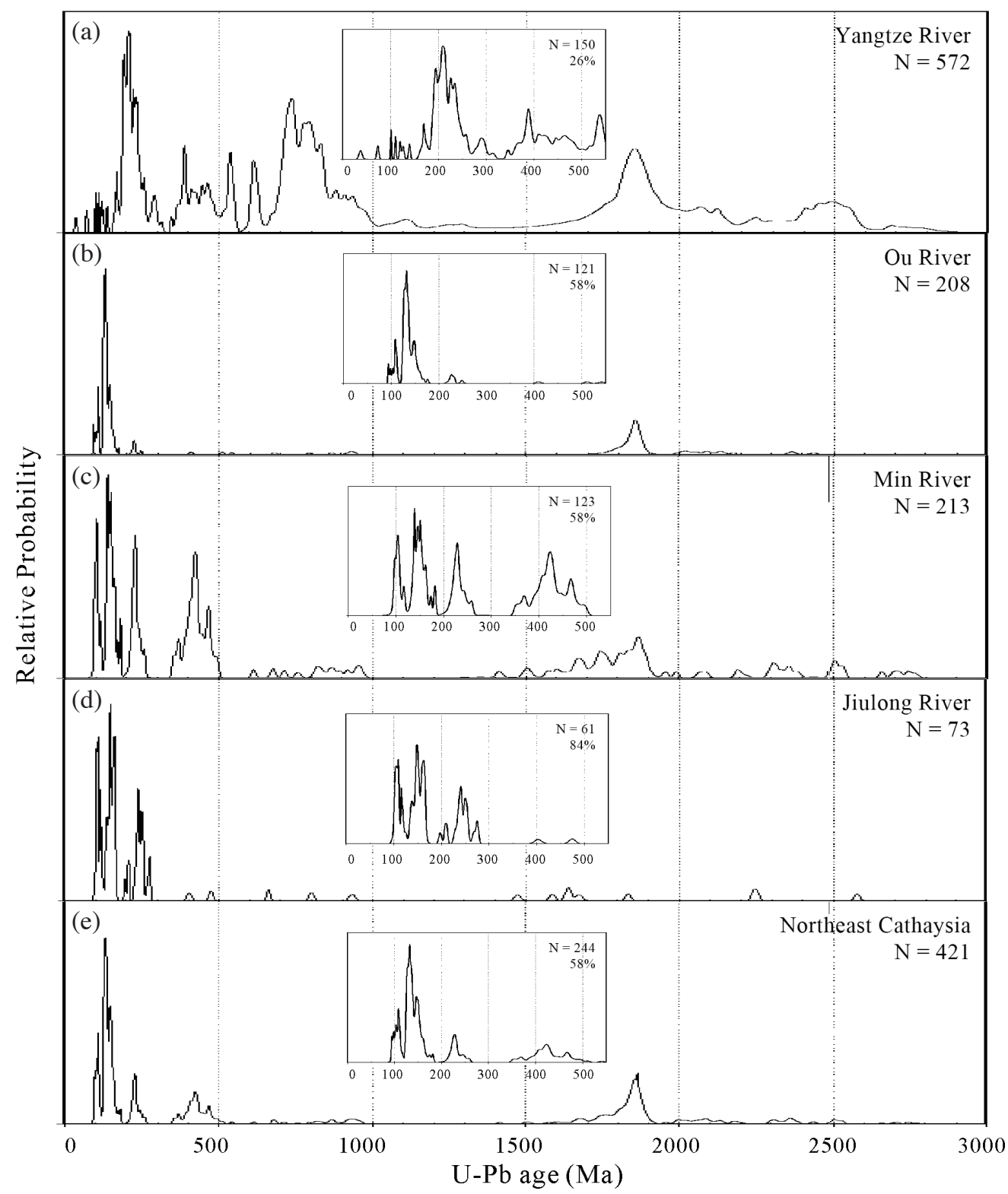

Fig. 5. U-Pb zircon age spectrum of the major potential sources. Data sources: (a) Yang et al. 2012; (b) Xu et al. 2007; (c) and (d): this study; (e): (b) + (c). 
at $\sim 1.8 \mathrm{Ga}$ and $\sim 420 \mathrm{Ma}$, which appear to be distinctive of the western Taiwan Island. Thus, the Min River likely supplies a portion of the detrital materials to western Taiwan beaches. Nevertheless, U-Pb ages revealed that the detrital zircons of the Jiulong River estuary do not have characteristic Precambrian and Caledonian peaks, indicating that this river is unlikely to provide materials to beaches of western Taiwan. Furthermore, based on the U-Pb ages and Hf isotopes of the detrital zircons of central Taiwan and compared the data with the U-Pb and $\varepsilon_{\mathrm{Hf}}(\mathrm{t})$ data of the zircons in the Cathaysia Block (Lan et al. 2009), it was also clear that they have the same origin. Hence, the authors reasoned that the Min River plays a crucial role in the transportation and supply of detrital sediments to western Taiwan.

\subsection{Implications for Crustal Evolution}

The Ou River and the Min River in northeast Cathaysia Block both have a large number of Paleoproterozoic zircons, which contain information of the Paleoproterozoic basement (Wuyishan). However, the zircon U-Pb age and $\varepsilon_{\mathrm{Hf}}(\mathrm{t})$ from Jiulong River are significantly different from these from Min River. Yu et al. (2010) suggested that the Cathaysia Block can be roughly divided into the Wuyishan area in the northeast and the Nanling-Yunkai-Hainan area in the southwest. Here, we just discuss the crustal evolution of northeast Cathaysia Block.

Whether the Cathaysia Block contains ancient crystalline basement remains controversial. Recently, Archean detrital zircons and minor inherited or xenocrystic zircons have been found in Wuyishan regions (Wan et al. 2007; Yu et al. 2009, 2012). Yu et al. (2012) found a large proportion of Archaean zircons (3.7 - 3.6, 3.2 - 3.0, 2.7 - 2.6, and 2.5 Ga) in the Badu Group Complex. In addition, some Archean debris had been discovered in Paleoproterozoic amphibolite in Jianning, Fujian ( $\mathrm{Li}$ et al. 1998). In this study, nine Neoarchean detrital zircons (2504 - $2765 \mathrm{Ma}$ ) in Min River were identified, with $\varepsilon_{\mathrm{Hf}}(\mathrm{t})$ varying from +6.5 to -6.8 . The two-stage $\mathrm{Hf}$ model age of the zircons in this age group is 2.6 - 3.6 Ga (Fig. 4b), which suggested the juvenile crust of the Badu area in north Cathaysia was mainly formed in 2.5 - 2.8 Ga (Yu et al. 2012). These data imply that the Neoarchean zircons include both juvenile mantle-derived components and the reworked crustal materials.

The $\varepsilon_{\mathrm{Hf}}(\mathrm{t})$ values of Paleoproterozoic zircons exhibit a wide range from negative to positive $(-16.1$ to +3.9$)$ (Fig. 4b), indicating that the northeast Cathaysia involved extensive reworking of older crust with litter juvenile crustal growth (Xu et al. 2007). Zircons with U-Pb ages of 1.5 - $1.0 \mathrm{Ga}$ were extremely rare, reflecting that the northeast Cathaysia Block experienced long-term tectonic stability during that period. The wide ranges in $\varepsilon_{\mathrm{Hf}}(\mathrm{t})$ values $(-14.2$ to +2.6$)$ in the Neoproterozoic indicated re-melting of ancient crustal material with minor juvenile mantle input.
The zircons of Neoproterozoic mafic rocks show positive $\varepsilon_{\mathrm{Hf}}(\mathrm{t})$ values, suggesting that they originated from a depleted mantle source (Shu et al. 2011). In the groups spanning 100 - $500 \mathrm{Ma}$, the northeast Cathaysia Block has been influenced by the Caledonian, Hercynian-Indosinian and Yanshanian orogenies. Most of Phanerozoic zircons (93\%) have negative $\varepsilon_{\mathrm{Hf}}(\mathrm{t})$ values, and only twelve grains have positive $\varepsilon_{\mathrm{Hf}}(\mathrm{t})$ values. Their $\mathrm{T}_{\mathrm{DM} 2}$ values were predominantly within the range of 0.7 - $2.5 \mathrm{Ga}$ with wide ranges in Hf-isotope composition, indicating that the Phanerozoic zircons stemmed from re-melting and recycling of the Proterozoic crustal materials, with or without juvenile mantle-derived magmas (Liu et al. 2012; Wang et al. 2013).

\section{CONCLUSIONS}

(1) Detrital zircons from the Min River and Jiulong River display Indosinian and Jurassic-Cretaceous characteristic peaks indicating that the detrital sediments were mainly supplied by Indosinian material of the upstream regions as well as Jurassic-Cretaceous materials from the middle and lower reaches. In addition, the detrital zircons from the Min River estuary display a prominent Caledonian peak and contain greater proportion of Precambrian particles, implying that these detrital substances originated from the upstream area of Wuyishan.

(2) Given that Taiwan Island cannot supply the Caledonian and Paleoproterozoic detrital material, and that the $\mathrm{Ou}$ and Jiulong River estuary lack components from these two periods, it is highly likely that the beach debris in western Taiwan coast partially originates from the Min River. Our study of zircons from Min River confirms the finding of Chen et al. (2006) that the sediments from the Min River in Fujian are considered the most likely source of the beach sands of the western Taiwan. However, we stress that the $\sim 1.8 \mathrm{Ga}$ age source in the western Taiwan sediments was founded and recognized.

(3) The northeast Cathaysia Block contains some Neoarchean detrital zircons, which derived from incorporation between juvenile mantle material and re-melt ancient crustal substances. Wide ranges in $\varepsilon_{\mathrm{Hf}}(\mathrm{t})$ values in the Paleoproterozoic and Neoproterozoic indicated remelting of ancient crustal material with minor juvenile mantle materials. Phanerozoic zircons stemmed from remelting and recycling of the Proterozoic crustal materials with or without juvenile mantle-derived magmas.

Acknowledgments This work was financially supported by the National Natural Science Foundation of China (NSFC 40906047 and 41106073), Scientific Research Foundation of Third Institute of Oceanography (SOA. NO. 2014015) and Natural Science Foundation of Fujian Province (2010J05096). We are grateful to Dr. Yanyan Zhou and Dr. Yueheng Yang for their assistance with the analyses. We also thank Mei-Fei 
Chu, Kuo-Lung Wang and one anonymous reviewer for their helpful comments.

\section{REFERENCES}

Amelin, Y., D. C. Lee, A. N. Halliday, and R. T. Pidgeon, 1999: Nature of the Earth's earliest crust from hafnium isotopes in single detrital zircons. Nature, 399, 252255, doi: 10.1038/20426. [Link]

Andersen, T., 2002: Correction of common lead in U-Pb analyses that do not report ${ }^{204} \mathrm{~Pb}$. Chem. Geol., 192, 5979, doi: 10.1016/S0009-2541(02)00195-X. [Link]

Andersen, T., 2005: Detrital zircons as tracers of sedimentary provenance: Limiting conditions from statistics and numerical simulation. Chem. Geol., 216, 249-270, doi: 10.1016/j.chemgeo.2004.11.013. [Link]

Bouvier, A., J. D. Vervoort, and P. J. Patchett, 2008: The $\mathrm{Lu}-\mathrm{Hf}$ and $\mathrm{Sm}-\mathrm{Nd}$ isotopic composition of CHUR: Constraints from unequilibrated chondrites and implications for the bulk composition of terrestrial planets. Earth Planet. Sci. Lett., 273, 48-57, doi: 10.1016/j. eps1.2008.06.010. [Link]

Cawood, P. A., A. A. Nemchin, M. Freeman, and K. Sircombe, 2003: Linking source and sedimentary basin: Detrital zircon record of sediment flux along a modern river system and implications for provenance studies. Earth Planet. Sci. Lett., 210, 259-268, doi: 10.1016/ S0012-821X(03)00122-5. [Link]

Chen, C. H., H. Y. Lu, W. Lin, and C. Y. Lee, 2006: Thermal event records in SE China coastal areas: Constraints from Monazite Ages of Beach Sands from two sides of the Taiwan Strait. Chem. Geol., 231, 118-134, doi: 10.1016/j.chemgeo.2006.01.023. [Link]

Chen, C. H., C. Y. Lee, P. S. Hsieh, W. Zeng, and H. W. Zhou, 2008: Approaching the age problem for some metamorphosed Precambrian basement rocks and Phanerozoic granitic bodies in the Wuyishan area: The application of EMP monazite age dating. Geol.J.Chin. Univ., 14, 1-15. (in Chinese)

Chen, J. and B. Jahn, 1998: Crustal evolution of southeastern China: Nd and $\mathrm{Sr}$ isotopic evidence. Tectonophysics, 284, 101-133, doi: 10.1016/S0040-1951(97)00186-8. [Link]

Compston, W., I. S. Williams, J. L. Kirschvink, Z. Zhang, and M. A. Guogan, 1992: Zircon U-Pb ages for the Early Cambrian time-scale. J. Geol. Soc., 149, 171184, doi: 10.1144/gsjgs.149.2.0171. [Link]

Condie, K. C., E. Beyer, E. Belousova, W. L. Griffin, and S. Y. O'Reilly, 2005: U-Pb isotopic ages and $\mathrm{Hf}$ isotopic composition of single zircons: The search for juvenile Precambrian continental crust. Precambrian Res., 139, 42-100, doi: 10.1016/j.precamres .2005.04.006. [Link]

Dadson, S. J., N. Hovius, H. Chen, W. B. Dade, M. L. Hsieh, S. D. Willett, J. C. Hu, M. J. Horng, M. C. Chen,
C. P. Stark, D. Lague, and J. C. Lin, 2003: Links between erosion, runoff variability and seismicity in the Taiwan orogen. Nature, 426, 648-651, doi: 10.1038/ nature 02150 . [Link]

Griffin, W. L., N. J. Pearson, E. Belousova, S. E. Jackson, E. van Achterbergh, S. Y. O'Reilly, and S. R. Shee, 2000: The Hf isotope composition of cratonic mantle: LAM-MC-ICPMS analysis of zircon megacrysts in kimberlites. Geochim. Cosmochim. Acta, 64, 133-147, doi: 10.1016/S0016-7037(99)00343-9. [Link]

Griffin, W. L., X. Wang, S. E. Jackson, N. J. Pearson, S. Y. O'Reilly, X. Xu, and X. Zhou, 2002: Zircon chemistry and magma mixing, SE China: In-situ analysis of Hf isotopes, Tonglu and Pingtan igneous complexes. Lithos, 61, 237-269, doi: 10.1016/S0024-4937(02)000828. [Link]

Guo, C. L., J. H. Zheng, F. S. Lou, and Z. L. Zeng, 2012: Petrography, genetic types and geological dynamical settings of the Indosinian granitoids in South China. Geotectonica et Metallogenia, 36, 457-472, doi: 10.3969/j. issn.1001-1552.2012.03.020. (in Chinese) [Link]

Iizuka, T., T. Hirata, T. Komiya, S. Rino, I. Katayama, A. Motoki, and S. Maruyama, 2005: U-Pb and Lu-Hf isotope systematics of zircons from the Mississippi River sand: Implications for reworking and growth of continental crust. Geology, 33, 485-488, doi: 10.1130/ G21427.1. [Link]

Jackson, S. E., N. J. Pearson, W. L. Griffin, and E. A. Belousova, 2004: The application of laser ablation-inductively coupled plasma-mass spectrometry to in situ U-Pb zircon geochronology. Chem. Geol., 211, 47-69, doi: 10.1016/j.chemgeo.2004.06.017. [Link]

Lan, C. Y., C. S. Lee, T. F. Yui, H. T. Chu, and B. M. Jahn, 2008: The tectono-thermal events of Taiwan and their relationship with SE China. Terr. Atmos. Ocean. Sci., 19, 257-278, doi: 10.3319/TAO.2008.19.3.257(TT). [Link]

Lan, C. Y., T. Usuki, K. L. Wang, T. F. Yui, K. Okamoto, Y. H. Lee, T. Hirata, Y. Kon, Y. Orihashi, J. G. Liou, and C. S. Lee, 2009: Detrital zircon evidence for the antiquity of Taiwan. Geosci. J., 13, 233-243, doi: 10.1007/ s12303-009-0023-3. [Link]

Li, X. H., Y. X. Wang, Z.H. Zhao, D. F. Chen, and Z. Hong, 1998: SHRIMP U-Pb zircon geochronology for amphibolite from the Precambrian basement in SW Zhejiang and NW Fujian provinces. Geochimica, 27, 327-334. (in Chinese)

Li, Z. X. and X. H. Li, 2007: Formation of the 1300-kmwide intracontinental orogen and postorogenic magmatic province in Mesozoic South China: A flat-slab subduction model. Geology, 35, 179-182, doi: 10.1130/ G23193A.1. [Link]

Li, Z. X., L. Zhang, and C.M. Powell, 1995: South China in Rodinia: part of the missing link between Australia-East 
Antarctica and Laurentia? Geology, 23, 407-410, doi: 10.1130/0091-7613(1995)023<0407:SCIRPO>2.3.CO; 2. [Link]

Li, Z. X., X. H. Li, H. Zhou, and P. D. Kinny, 2002: Grenvillian continental collision in South China: New SHRIMP U-Pb zircon results and implications for the configuration of Rodinia. Geology, 30, 163-166, doi: 1 0.1130/0091-7613(2002)030<0163:GCCISC $>2.0 . C O$; 2. [Link]

Liu, C. Z., H. L. Jia, and X.F. Chen, 2001: Sedimentary texture and sedimentation in the Minjiang River estuary. Oceanol. Limnol. Sin., 32, 177-184. (in Chinese)

Liu, J. T., K. Liu, and J. C. Huang, 2002: The effect of a submarine canyon on the river sediment dispersal and inner shelf sediment movements in southern Taiwan. Mar. Geol., 181, 357-386, doi: 10.1016/S00253227(01)00219-5. [Link]

Liu, Q., J. H. Yu, Q. Wang, B. Su, M. F. Zhou, H. Xu, and X. Cui, 2012: Ages and geochemistry of granites in the Pingtan-Dongshan Metamorphic Belt, Coastal South China: New constraints on Late Mesozoic magmatic evolution. Lithos, 150, 268-286, doi: 10.1016/j.lithos.2012.06.031. [Link]

Ludwig, K. R., 2003: User's Manual for Isoplot 3.00: A Geochronological Toolkit for Microsoft Excel, Special publication, Berkeley Geochronology Center, No. 4, Berkeley, Calif.

Pearce, N. J. G., W. T. Perkins, J. A. Westgate, M. P. Gorton, S. E. Jackson, C. R. Neal, and S. P. Chenery, 1997: A compilation of new and published major and trace element data for NIST SRM 610 and NIST SRM 612 glass reference materials. Geostand. Geoanal. Res., 21, 115144, doi: 10.1111/j.1751-908X.1997.tb00538.x. [Link]

Sano, Y., N. Takahata, Y. Tsutsumi, and T. Miyamoto, 2006: Ion microprobe U-Pb dating of monazite with about five micrometer spatial resolution. Geochem. J., 40, 597-608.

Shu, L. S., M. Faure, J. H. Yu, and B. M. Jahn, 2011: Geochronological and geochemical features of the Cathaysia block (South China): New evidence for the Neoproterozoic breakup of Rodinia. Precambrian Res., 187, 263-276, doi: 10.1016/j.precamres.2011.03.003. [Link]

Söderlund, U., P. J. Patchett, J. D. Vervoort, and C. E. Isachsen, 2004: The ${ }^{176} \mathrm{Lu}$ decay constant determined by $\mathrm{Lu}-$ $\mathrm{Hf}$ and $\mathrm{U}-\mathrm{Pb}$ isotope systematics of Precambrian mafic intrusions. Earth Planet. Sci. Lett., 219, 311-324, doi: 10.1016/S0012-821X(04)00012-3. [Link]

Sun, T., 2006: A new map showing the distribution of granites in South China and its explanatory notes. Geol. Bull. Chin., 25, 332-335. (in Chinese)

Veevers, J. J., A. Saeed, E. A. Belousova, and W. L. Griffin, 2005: U-Pb ages and source composition by Hf-isotope and trace-element analysis of detrital zircons in Permian sandstone and modern sand from southwestern Australia and a review of the paleogeographical and denudational history of the Yilgarn Craton. Earth-Sci.Rev., 68, 245-279, doi: 10.1016/j.earscirev .2004.05.005. [Link]

Vermeesch, P., 2004: How many grains are needed for a provenance study? Earth Planet. Sci. Lett., 224, 441451, doi: 10.1016/j.eps1.2004.05.037. [Link]

Wan, Y., D. Liu, M. Xu, J. Zhuang, B. Song, Y. Shi, and L. $\mathrm{Du}, 2007$ : SHRIMP U-Pb zircon geochronology and geochemistry of metavolcanic and metasedimentary rocks in Northwestern Fujian, Cathaysia block, China: Tectonic implications and the need to redefine lithostratigraphic units. Gondwana Res., 12, 166-183, doi: 10.1016/j.gr.2006.10.016. [Link]

Wang, C. Y., I. H. Campbell, A. S. Stepanov, C. M. Allen, and I. N. Burtsev, 2011: Growth rate of the preserved continental crust: II. Constraints from $\mathrm{Hf}$ and $\mathrm{O}$ isotopes in detrital zircons from Greater Russian Rivers. Geochim. Cosmochim. Acta, 75, 1308-1345, doi: 10.1016/j.gca.2010.12.010. [Link]

Wang, X. L., J. C. Zhou, W. L. Griffin, R. C. Wang, J. S. Qiu, S. Y. O'Reilly, X. Xu, X. M. Liu, and G.L.Zhang, 2007: Detrital zircon geochronology of Precambrian basement sequences in the Jiangnan orogen: Dating the assembly of the Yangtze and Cathaysia Blocks. Precambrian Res., 159, 117-131, doi: 10.1016/j.precamres.2007.06.005. [Link]

Wang, Y., W. Fan, G. Zhang, and Y. Zhang, 2013: Phanerozoic tectonics of the South China Block: key observations and controversies. Gondwana Res., 23, 12731305, doi: 10.1016/j.gr.2012.02.019. [Link]

Wu, F. Y., Y. H. Yang, L. W. Xie, J. H. Yang, and P. $\mathrm{Xu}, 2006$ : Hf isotopic compositions of the standard zircons and baddeleyites used in U-Pb geochronology. Chem. Geol., 234, 105-126, doi: 10.1016/j.chemgeo.2006.05.003. [Link]

Wu, F., X. Li, Y. Zheng, and S. Gao, 2007: Lu-Hf isotopic systematics and their applications in petrology. Acta Petrol. Sin., 23, 185-220, doi: 10.3321/j.issn:10000569.2007.02.001. (in Chinese) [Link]

Xie, L., Y. Zhang, H. Zhang, J. Sun, and F. Wu, 2008: In situ simultaneous determination of trace elements, $\mathrm{U}-\mathrm{Pb}$ and $\mathrm{Lu}-\mathrm{Hf}$ isotopes in zircon and baddeleyite. Chin. Sci. Bull., 53, 1565-1573, doi: 10.1007/s11434008-0086-y. [Link]

Xu, K., J. D. Milliman, A. Li, J. P. Liu, S. J. Kao, and S. Wan, 2009: Yangtze- and Taiwan-derived sediments on the inner shelf of East China Sea. Cont. Shelf Res., 29, 2240-2256, doi: 10.1016/j.csr.2009.08.017. [Link]

Xu, M., 1994: Study on fragmentary minerals surface sediments in Jiulong river estuary. J. Xiamen Univ., 33, 675-680. (in Chinese) 
Xu, X., 2008: Several problems worthy to be noticed in the research of granites and volcanic rocks in SE China. Geol. J. Chin. Univ., 14, 283-294. (in Chinese)

Xu, X., S. Y.O'Reilly, W.L. Griffin, X. Wang, N. J. Pearson, and Z. He, 2007: The crust of Cathaysia: age, assembly and reworking of two terranes. Precambrian Res., 158, 51-78, doi: 10.1016/j.precamres.2007.04.010. [Link]

Yang, J., S. Gao, C. Chen, Y. Tang, H. Yuan, H. Gong, S. Xie, and J. Wang, 2009: Episodic crustal growth of North China as revealed by U-Pb age and $\mathrm{Hf}$ isotopes of detrital zircons from modern rivers. Geochim. Cosmochim. Acta, 73, 2660-2673, doi: 10.1016/j. gca.2009.02.007. [Link]

Yang, S., F. Zhang, and Z. Wang, 2012: Grain size distribution and age population of detrital zircons from the Changjiang (Yangtze) River system, China. Chem. Geol., 296-297, 26-38, doi: 10.1016/j.chemgeo.2011.12.016. [Link]

Yu, J. H., L. Wang, S. Y. O’Reilly, W. L. Griffin, M. Zhang, C. Li, and L. Shu, 2009: A Paleoproterozoic orogeny recorded in a long-lived cratonic remnant (Wuyishan terrane), eastern Cathaysia Block, China. Precambrian Res., 174, 347-363, doi: 10.1016/j.precamres.2009.08.009. [Link]

Yu, J. H., S. Y. O’Reilly, L. Wang, W. L. Griffin, M. F. Zhou, M. Zhang, and L. Shu, 2010: Components and episodic growth of Precambrian crust in the Cathaysia Block, South China: Evidence from U-Pb ages and Hf isotopes of zircons in Neoproterozoic sediments. Precambrian Res., 181, 97-114, doi: 10.1016/j.precamres.2010.05.016. [Link]

Yu, J. H., S. Y. O’Reilly, M. F. Zhou, W. L. Griffin, and L. Wang, 2012: U-Pb geochronology and Hf-Nd isotopic geochemistry of the Badu Complex, Southeastern China: Implications for the Precambrian crustal evolution and paleogeography of the Cathaysia Block. Precambrian Res., 222-223, 424-449, doi: 10.1016/j. precamres.2011.07.014. [Link]

Zhao, G. and P. A. Cawood, 2012: Precambrian geology of China. Precambrian Res., 222-223, 13-54, doi: 10.1016/j.precamres.2012.09.017. [Link]

Zhao, L., J. Yu, L. Wang, L. Xie, T. Sun, and J. Qiu, 2006: Formation time of Hongshan topaz-bearing granite and its metallogenic potential prognosis. Mineral Deposits, 25, 672-682, doi: 10.3969/j.issn.02587106.2006.06.004. (in Chinese) [Link]

Zhou, X. M., 2003: My thinking about granite geneses of south China. Geol. J. Chin. Univ., 9, 556-565. (in Chinese)

Zhou, X. M., T. Sun, W. Z. Shen, L. S. Shu, and Y. L. Niu, 2006: Petrogenesis of Mesozoic granitoids and volcanic rocks in South China: A response to tectonic evolution. Episodes, 29, 26-33.

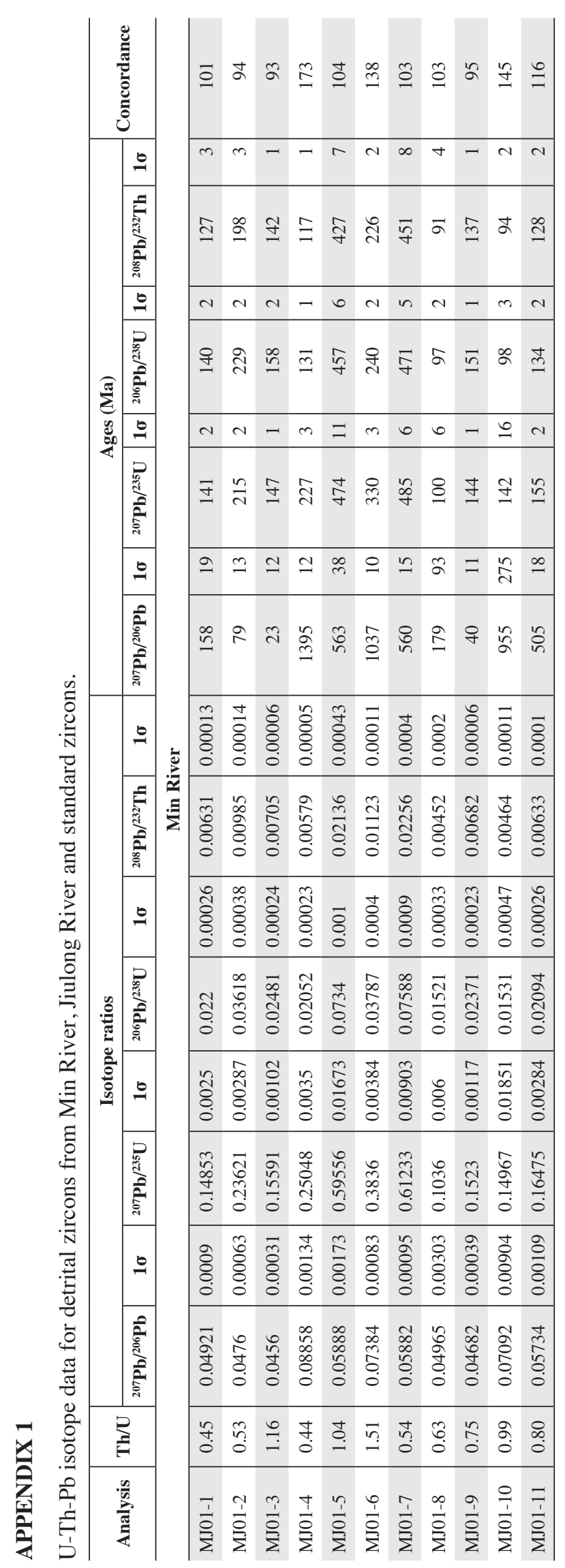




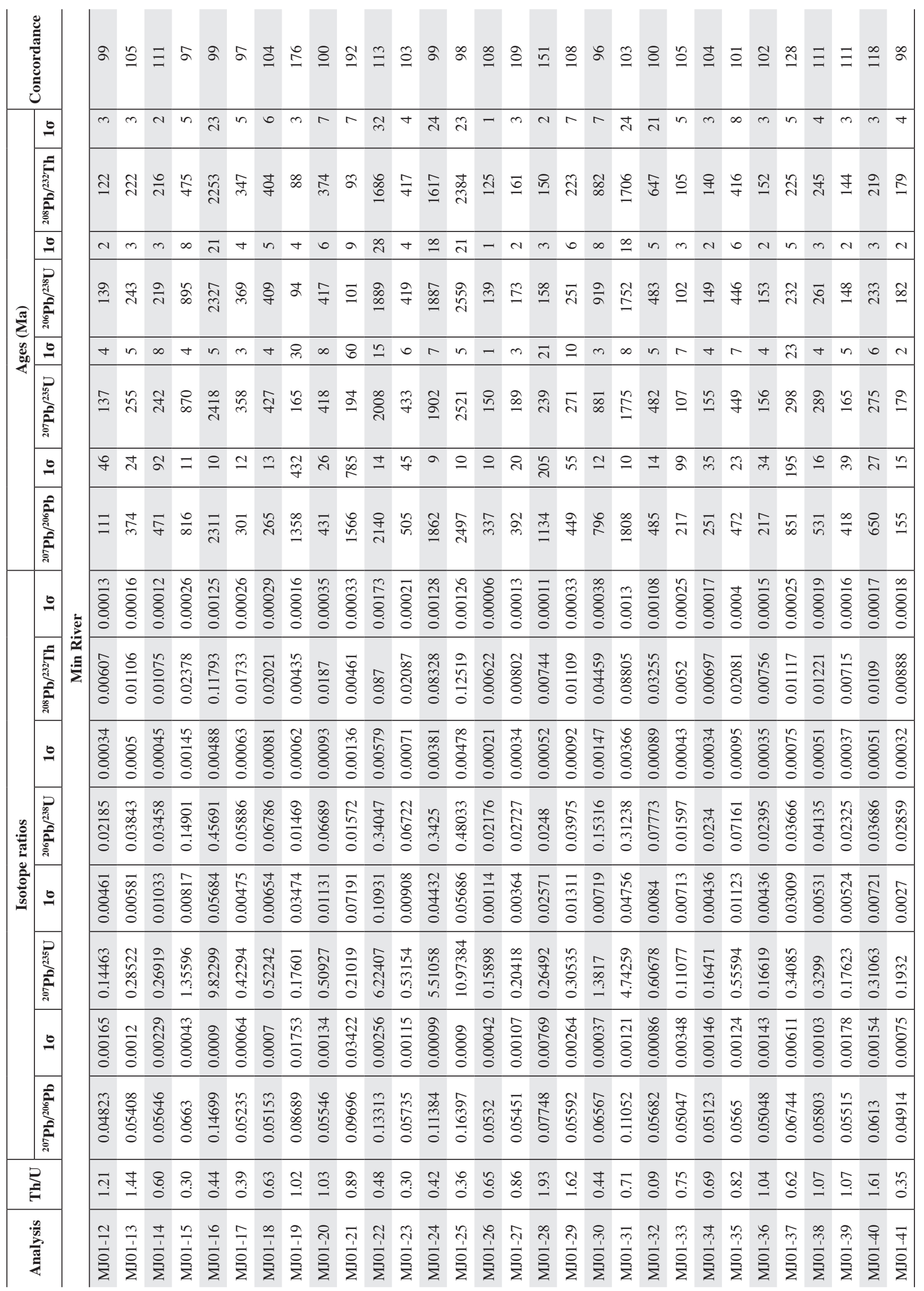




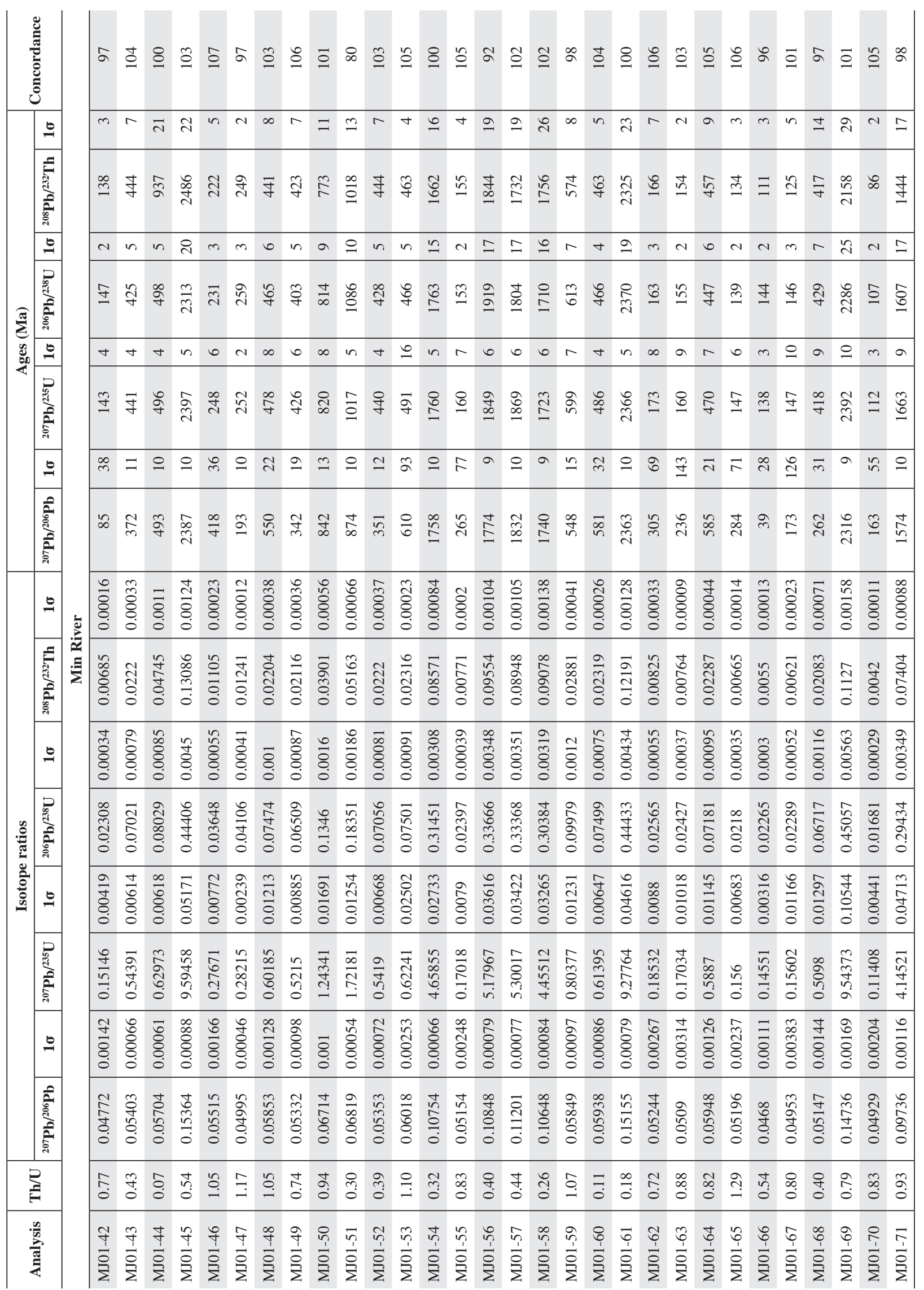




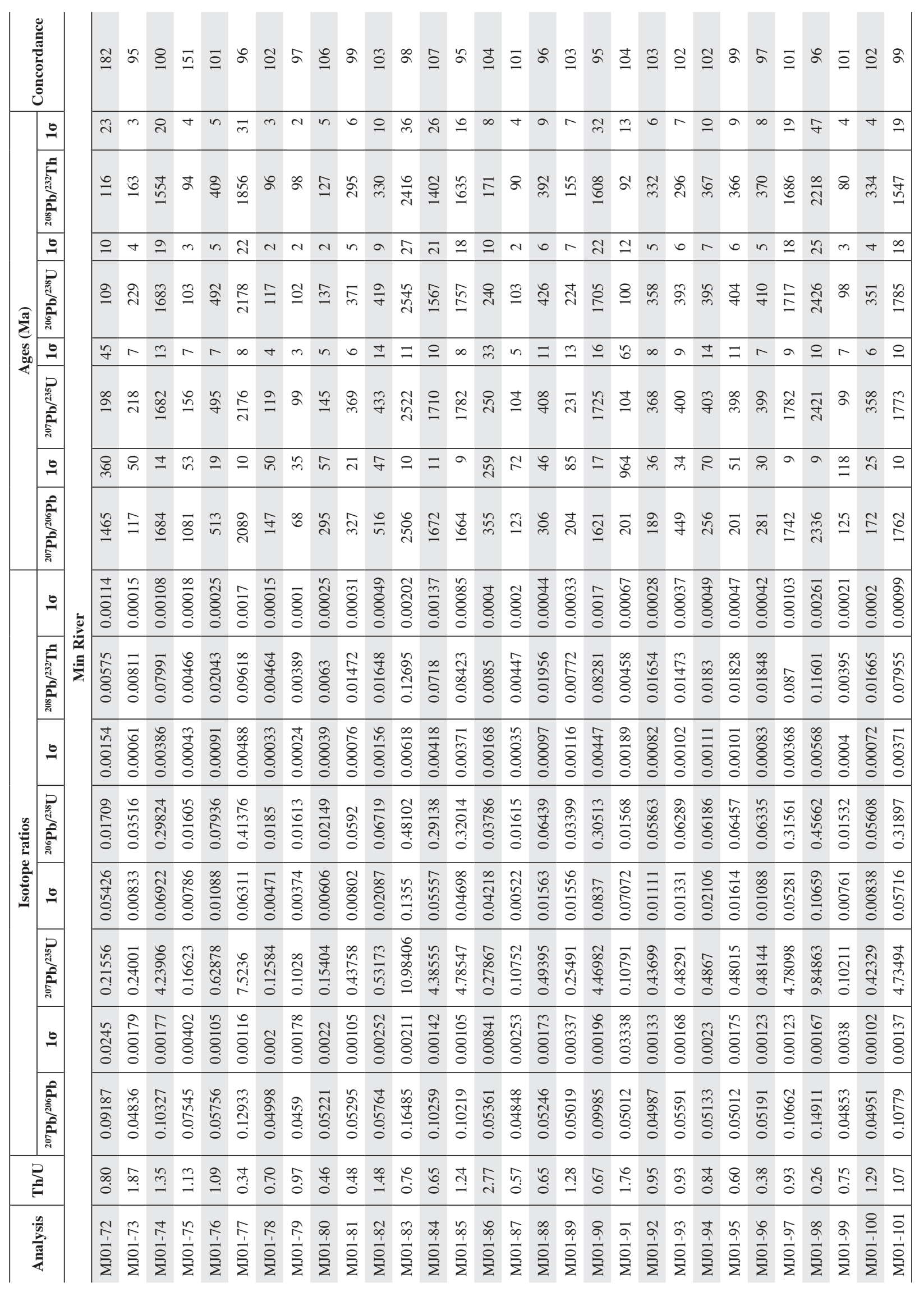




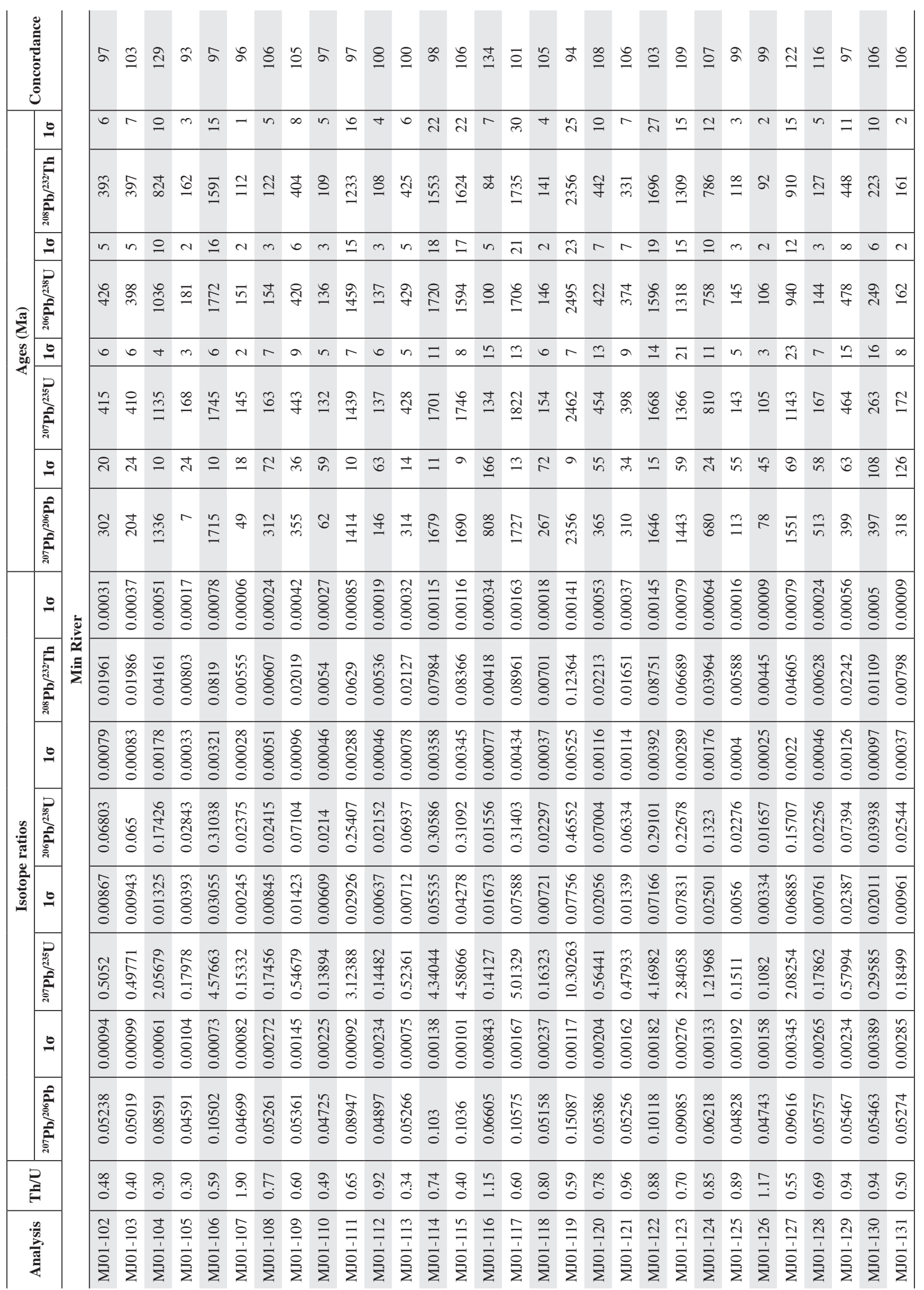




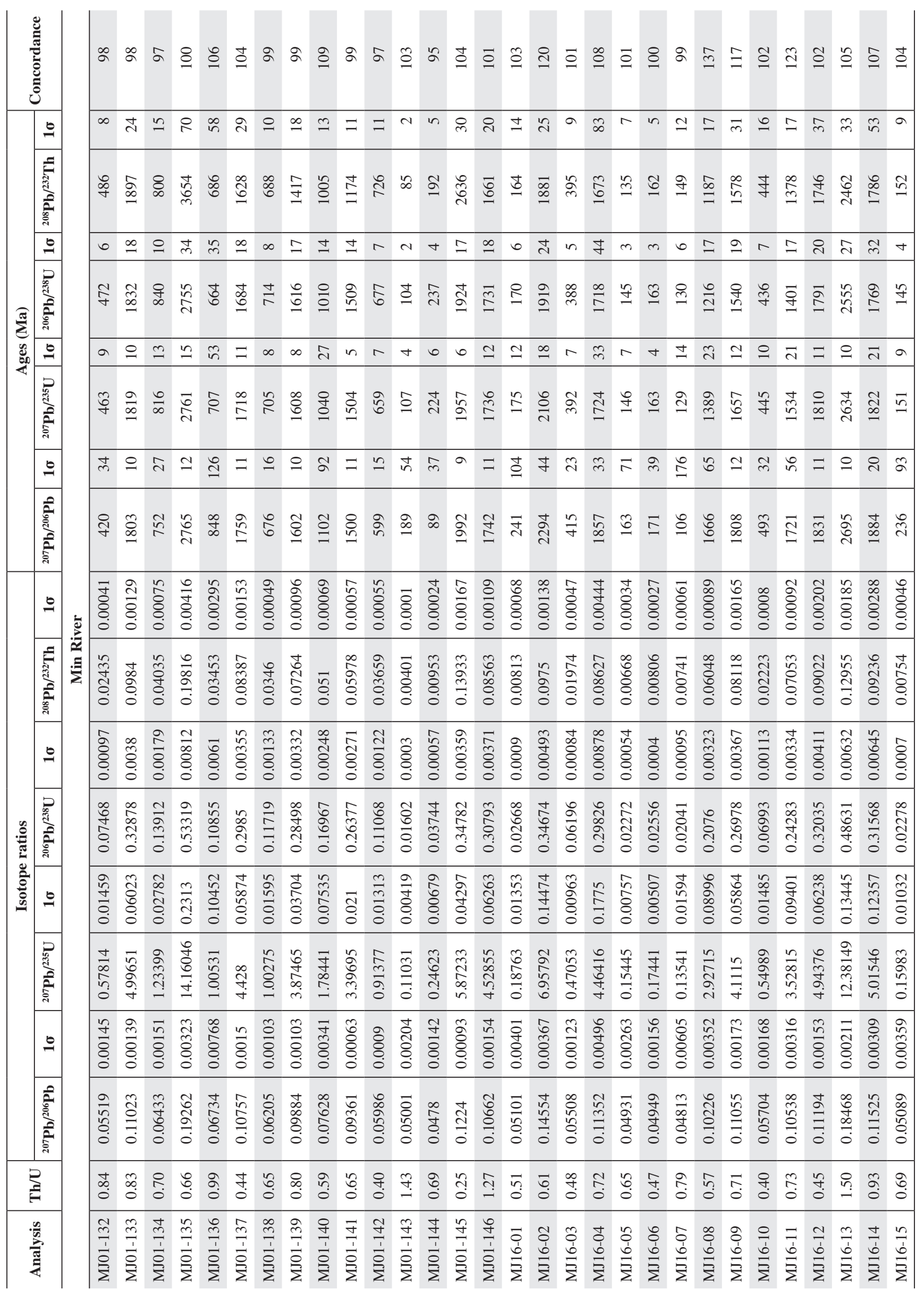




\begin{tabular}{|c|c|c|c|c|c|c|c|c|c|c|c|c|c|c|c|c|c|c|c|c|c|c|c|c|c|c|c|c|c|c|c|}
\hline \multicolumn{2}{|c|}{ 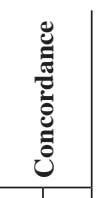 } & & & & & & & $\hat{6}$ & $\stackrel{8}{8}$ & 2 & $\stackrel{\Xi}{\Xi}$ & $\stackrel{\infty}{\varrho}$ & $\bar{\varrho}$ & $\stackrel{\infty}{\varrho}$ & $\stackrel{d}{0}$ & $\stackrel{\varrho}{\varrho}$ & $\hat{\varrho}$ & $\bar{\varrho}$ & ᄋิ & $\stackrel{\hat{g}}{\varrho}$ & \& & $\cong$ & \& & ఠิ & ฮิ & $\varrho$ & 으 & & $\stackrel{t}{0}$ & \& & $\hat{\varrho}$ \\
\hline \multirow{8}{*}{ 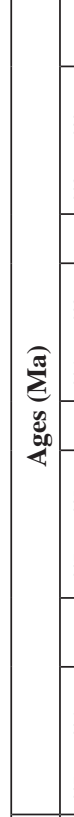 } & $\underline{\theta}$ & & ১ & & & 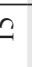 & $\sigma$ & $\ddot{n}$ & $\simeq$ & $a$ & q & 0 & $\mathscr{0}$ & 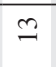 & $\vec{m}$ & $\ddot{\varkappa}$ & $\infty$ & $\nabla$ & $\stackrel{\infty}{\sim}$ & r & $\simeq$ & $\stackrel{0}{\simeq}$ & 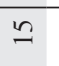 & \pm & $\stackrel{\infty}{\sim}$ & 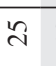 & $\simeq$ & $\vec{\sim}$ & f & 于 & $\vec{\sim}$ \\
\hline & 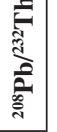 & & $\frac{\infty}{\pi}$ & & & 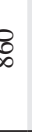 & $\vec{b}$ & さ્ & $\underline{\underline{0}}$ & $\frac{n}{7}$ & $\stackrel{2}{\beth}$ & $\stackrel{\infty}{\subseteq}$ & बे & $\stackrel{\varrho}{\mathrm{N}}$ & $\begin{array}{l}\tilde{n} \\
\tilde{n}\end{array}$ & స్రి & $\tilde{气}$ & సิ & 9 & 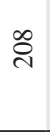 & శి & Э্ & $\stackrel{m}{\forall}$ & જे & तై & 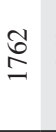 & ถู হ & 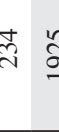 & बूे & 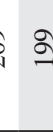 & 吉 \\
\hline & $\underline{\theta}$ & & $\stackrel{9}{9}$ & & 3 & $\infty$ & $\infty$ & $\stackrel{\infty}{\rightarrow}$ & 0 & $n$ & $\stackrel{\Xi}{\sim}$ & $m$ & $r$ & $\exists$ & $\stackrel{ \pm}{N}$ & $\approx$ & + & m & $\stackrel{i}{*}$ & in & $r$ & $r$ & 0 & 0 & 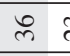 & $\tilde{\lambda}$ & $=0$ & 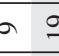 & $=\infty$ & 1 & $r$ \\
\hline & 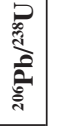 & & & & & $\infty$ & $\infty$ & $\stackrel{\infty}{I}$ & 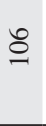 & $\stackrel{\infty}{\vec{\gamma}}$ & $\stackrel{8}{\stackrel{n}{=}}$ & $\stackrel{\varrho}{=}$ & $\underset{\substack{\infty \\
\infty}}{ }$ & $\stackrel{\circ}{\mathrm{N}}$ & 怘 & $\widehat{\widehat{\delta}}$ & $\stackrel{0}{\curvearrowleft}$ & $\stackrel{\mathbb{N}}{\mathbb{N}}$ & ઠิ & $\stackrel{\circlearrowright}{\sim}$ & $\widehat{\vartheta}$ & $\vec{q}$ & $\stackrel{\partial}{\vec{\gamma}}$ & के & $\stackrel{0}{\frac{\pi}{N}}$ & $\stackrel{?}{I}$ & ఫૂ ઈૂ & તે & 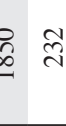 & $\stackrel{t}{\Xi}$ & ซิ \\
\hline & $\underline{\theta}$ & 7 & $r$ & & 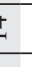 & $n$ & $\infty$ & $a$ & \pm & 0 & 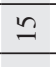 & $r$ & $=$ & $\stackrel{\Delta}{\sim}$ & $\infty$ & $\bar{\lambda}$ & $a$ & $\nabla$ & $\stackrel{0}{0}$ & $a$ & 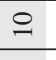 & $\exists$ & $a$ & $\infty$ & त) & $=$ & $a \quad$ & $\stackrel{\infty}{\infty}$ & I & 5 & $a$ \\
\hline & 范 & & & & 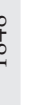 & $\vec{\infty}$ & $\infty$ & ્ֻతి & 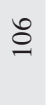 & $\stackrel{M}{\forall}$ & $\stackrel{ \pm}{\stackrel{ \pm}{\Xi}}$ & $\stackrel{\beth}{\cong}$ & ஓి & §̊ & 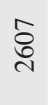 & బิ & $\vec{\sigma}$ & సి & $\stackrel{\stackrel{\sim}{\sim}}{\sim}$ & 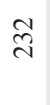 & $\stackrel{\infty}{\Im}$ & $\stackrel{?}{f}$ & F & $\stackrel{\infty}{\leftarrow}$ & $\stackrel{\tilde{\vec{\lambda}}}{2}$ & $\stackrel{0}{\stackrel{\infty}{-}}$ & నૂ ఓ̊ & స్ & E) & $\tilde{\tilde{N}}$ & 字 \\
\hline & $\underline{\theta}$ & & $\circ$ & & $t$ & $\underline{b}$ & $m$ & $a$ & $\cong$ & ๙ి & \pm & $\stackrel{\infty}{\curvearrowright}$ & f & $\stackrel{ }{=}$ & $a$ & $尺$ & $\tilde{\infty}$ & in & F & $i n$ & n & $\stackrel{r}{m}$ & $m$ & ส & $=$ & + & 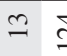 & $\stackrel{\Delta}{\Xi}$ & $0 \cong$ & $\exists$ & $\stackrel{\infty}{i}$ \\
\hline & 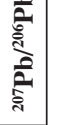 & & & & & $\begin{array}{l}\infty \\
\infty \\
\infty\end{array}$ & $\begin{array}{c}\mathbb{D}_{\infty} \\
\infty\end{array}$ & 年 & $\tilde{\alpha}$ & $\underset{\infty}{\infty}$ & $\begin{array}{l}\tilde{1} \\
\stackrel{\infty}{-}\end{array}$ & ১্ & \&̊ & ๙ૂ & $\begin{array}{l}\text { : } \\
\text { Cे }\end{array}$ & $\stackrel{\substack{0 \\
0}}{0}$ & ले & 竎 & $\stackrel{\infty}{\stackrel{\infty}{\lambda}}$ & ஓ) & $\tilde{F}$ & i̊n & 志 & 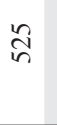 & $\begin{array}{l}\text { ठे } \\
\text { ? }\end{array}$ & $\begin{array}{l}n \\
2 \\
\infty \\
\infty\end{array}$ & $\begin{array}{l}\infty \\
\infty\end{array}$ & & $\delta$ & $\frac{\pi}{\pi}$ & సิ \\
\hline \multirow{8}{*}{ 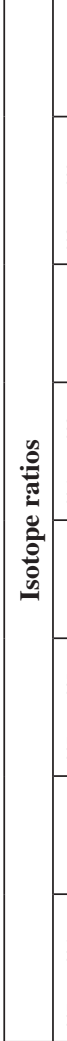 } & $\stackrel{\theta}{-}$ & & $\begin{array}{l}\ddot{m} \\
\frac{1}{c}\end{array}$ & & & $\begin{array}{l}\infty \\
8 \\
8 \\
0 \\
0\end{array}$ & \begin{tabular}{l}
0 \\
\multirow{2}{*}{} \\
8 \\
0 \\
0
\end{tabular} & 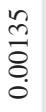 & $\begin{array}{l}\overrightarrow{0} \\
8 \\
8 \\
0\end{array}$ & 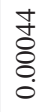 & 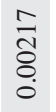 & 厄̂. & $\begin{array}{l}0 \\
0 \\
\delta \\
8 \\
0\end{array}$ & $\begin{array}{l}\circ \\
\varnothing \\
8 \\
0\end{array}$ & $\frac{n}{\frac{n}{8}}$ & $\frac{n}{m}$ & $\begin{array}{l}\text { चे } \\
8 \\
8 \\
0\end{array}$ & $\frac{\infty}{8}$ & $\frac{n}{n}$ & 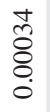 & 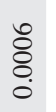 & 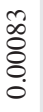 & 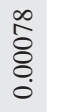 & 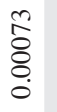 & ते & $\begin{array}{l}m \\
\frac{2}{8} \\
\stackrel{0}{0}\end{array}$ & 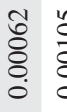 & $\begin{array}{l}0 \\
\frac{c}{8} \\
0 \\
0\end{array}$ & & $\bar{c}$ & 告 \\
\hline & 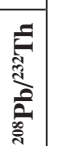 & 8 & & & & 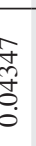 & ్ֶ & 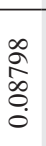 & 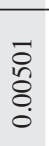 & 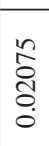 & $\begin{array}{l}\overrightarrow{\bar{\sigma}} \\
\stackrel{\sigma}{0} \\
\stackrel{0}{0}\end{array}$ & $\begin{array}{l}\approx \\
\hat{\delta} \\
\varnothing \\
0\end{array}$ & $\begin{array}{l}\stackrel{\partial}{\circ} \\
\frac{\partial}{0}\end{array}$ & $\begin{array}{l}\frac{2}{0} \\
\frac{1}{0} \\
0 \\
0\end{array}$ & 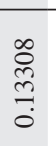 & $\begin{array}{l}\text { ते } \\
\text { ळे } \\
\stackrel{0}{0} \\
\stackrel{0}{0}\end{array}$ & 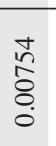 & $\begin{array}{l}\stackrel{2}{\Xi} \\
\stackrel{0}{\sigma}\end{array}$ & $\frac{n}{\frac{0}{8}}$ & $\begin{array}{l}\hat{\sigma} \\
\stackrel{0}{0} \\
\stackrel{0}{0}\end{array}$ & $\begin{array}{l}\infty \\
\text { ठे } \\
\text { ठ. } \\
0\end{array}$ & 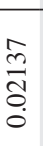 & 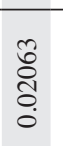 & $\begin{array}{l}\stackrel{+}{\Delta} \\
\text { Oे }\end{array}$ & 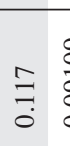 & $\begin{array}{l}\text { oे } \\
\frac{0}{a} \\
\text { o. }\end{array}$ & 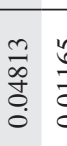 & 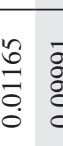 & & 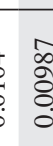 & $\left\{\begin{array}{l}\infty \\
\multirow{N}{\Delta}{} \\
0\end{array}\right.$ \\
\hline & $\stackrel{\theta}{0}$ & & z & & & $\begin{array}{l}\frac{a}{2} \\
\frac{d}{0} \\
0\end{array}$ & $\frac{n}{8}$ & 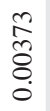 & $\begin{array}{l}0 \\
8 \\
8 \\
8 \\
0\end{array}$ & 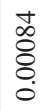 & 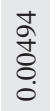 & ڤ̊̀ & $\stackrel{0}{1}$ & $\frac{\sqrt{5}}{8}$ & $\begin{array}{l}\vec{n} \\
\delta \\
\delta \\
0\end{array}$ & 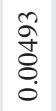 & 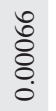 & 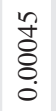 & 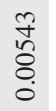 & $\begin{array}{l}0 \\
\hat{\delta} \\
8 \\
0 \\
0\end{array}$ & $\stackrel{\Xi}{\overline{8}}$ & $\frac{\vec{d}}{\stackrel{\Xi}{0}}$ & $\frac{8}{8}$ & $\begin{array}{l}\frac{\tilde{0}}{\sigma} \\
\stackrel{0}{0}\end{array}$ & 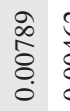 & 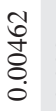 & ธి & & & $\bar{a}$ & $\frac{\pi}{8}$ \\
\hline & 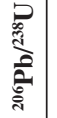 & & d & & & $\begin{array}{l}\frac{1}{0} \\
\vdots \\
\vdots \\
\\
\end{array}$ & $\frac{\text { Pे }}{0}$ & $\begin{array}{l}\sqrt[n]{\pi} \\
\stackrel{1}{\pi} \\
0\end{array}$ & $\begin{array}{l}\tilde{0} \\
\stackrel{0}{0} \\
0 \\
0\end{array}$ & $\begin{array}{l}\stackrel{5}{8} \\
\stackrel{0}{0} \\
0\end{array}$ & $\begin{array}{l}\stackrel{\Xi}{\Rightarrow} \\
\stackrel{m}{\sigma}\end{array}$ & $\begin{array}{l}0 \\
\infty \\
\infty \\
\stackrel{0}{0}\end{array}$ & $\begin{array}{l}\stackrel{0}{\circ} \\
\stackrel{0}{0}\end{array}$ & $\frac{m}{m}$ & 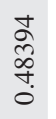 & 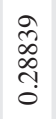 & 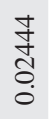 & 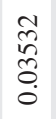 & 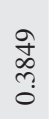 & 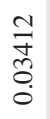 & $\begin{array}{l}n \\
2 \\
0 \\
0 \\
0\end{array}$ & 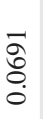 & $\begin{array}{l}\frac{0}{\widehat{े}} \\
\stackrel{0}{0}\end{array}$ & 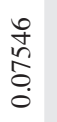 & $\begin{array}{l}\stackrel{+}{0} \\
0 \\
+ \\
0 \\
0\end{array}$ & 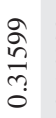 & 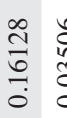 & & & 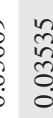 & 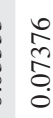 \\
\hline & $\underline{\theta}$ & & $\begin{array}{l}0 \\
0 \\
y \\
y \\
c\end{array}$ & & & 遂 & $\frac{2}{0}$ & 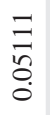 & $\begin{array}{l}\vec{\infty} \\
\stackrel{\infty}{+} \\
\\
0\end{array}$ & $\begin{array}{l}\widetilde{\alpha} \\
\stackrel{\alpha}{0} \\
\stackrel{0}{0}\end{array}$ & $\begin{array}{l}\text { हे } \\
\text { o. } \\
0 \\
0\end{array}$ & 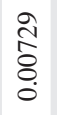 & $\begin{array}{l}\frac{a}{0} \\
\frac{0}{0} \\
0\end{array}$ & $\stackrel{\vec{m}}{\stackrel{\sigma}{0}}$ & $\begin{array}{l}\stackrel{\hat{0}}{0} \\
\stackrel{0}{0}\end{array}$ & 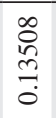 & $\begin{array}{l}\infty \\
\infty \\
o \\
8 \\
0\end{array}$ & $\begin{array}{l}\frac{m}{n} \\
\frac{8}{8} \\
0\end{array}$ & $\begin{array}{l}\vec{n} \\
\stackrel{0}{0} \\
0\end{array}$ & $\begin{array}{l}\text { ర్ర } \\
0 \\
0 \\
0\end{array}$ & $\begin{array}{l}\text { 苫 } \\
\text { م. } \\
0 \\
0\end{array}$ & $\begin{array}{l}\bar{\sigma} \\
\stackrel{0}{0} \\
\stackrel{0}{\circ}\end{array}$ & $\begin{array}{l}n \\
\tilde{c} \\
\vdots \\
0\end{array}$ & $\begin{array}{l}\frac{0}{3} \\
\stackrel{3}{0} \\
\stackrel{0}{0}\end{array}$ & $\begin{array}{l}4 \\
0 \\
0 \\
0 \\
0\end{array}$ & \begin{tabular}{l}
$\stackrel{8}{0}$ \\
\hdashline \\
0 \\
0
\end{tabular} & 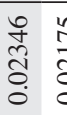 & & & $\frac{a}{\infty}$ & 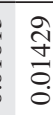 \\
\hline & 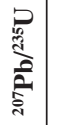 & & & & & 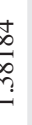 & & 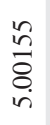 & $\begin{array}{l}\frac{n}{2} \\
\hat{0} \\
\frac{0}{0}\end{array}$ & $\begin{array}{l}\stackrel{2}{1} \\
\stackrel{1}{0} \\
0\end{array}$ & $\begin{array}{l}\stackrel{\vartheta}{\sigma} \\
\stackrel{\sigma}{+} \\
\dot{\sigma}\end{array}$ & $\begin{array}{l}\text { ț } \\
\stackrel{0}{0} \\
\stackrel{0}{0}\end{array}$ & $\begin{array}{l}\vec{J} \\
0 \\
0 \\
\vdots \\
0 \\
0\end{array}$ & $\begin{array}{l}\text { ర్రి } \\
\text { లై } \\
\text { o. }\end{array}$ & 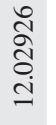 & $\begin{array}{l}\stackrel{P}{d} \\
\stackrel{+}{+} \\
\dot{f}\end{array}$ & $\underset{0}{\stackrel{N}{I}}$ & 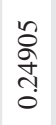 & 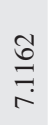 & 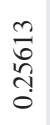 & $\begin{array}{l}\infty \\
\tilde{\infty} \\
\hat{n} \\
0\end{array}$ & 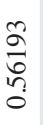 & $\begin{array}{l}n \\
\hat{s} \\
0 \\
0 \\
0\end{array}$ & 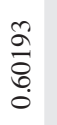 & 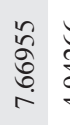 & 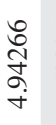 & 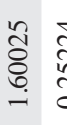 & 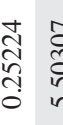 & & & $\begin{array}{l}n \\
2 \\
\infty \\
n \\
0\end{array}$ \\
\hline & $\stackrel{\theta}{-1}$ & & & & & 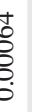 & $\frac{ \pm}{\Xi}$ & $\begin{array}{l}\stackrel{n}{a} \\
\stackrel{8}{8} \\
0\end{array}$ & $\begin{array}{l}\infty \\
\text { ठे } \\
8\end{array}$ & $\frac{n}{0}$ & $\begin{array}{l}0 \\
\stackrel{0}{\pi} \\
\stackrel{0}{0} \\
0\end{array}$ & $\begin{array}{l}\stackrel{े}{\tilde{\delta}} \\
\stackrel{0}{0}\end{array}$ & $\begin{array}{l}0 \\
\stackrel{్}{0} \\
8 \\
0\end{array}$ & $\begin{array}{l}n \\
0 \\
8 \\
0 \\
0\end{array}$ & $\begin{array}{l}\vec{b} \\
\overrightarrow{8} \\
0\end{array}$ & $\begin{array}{l}\infty \\
\infty \\
\tilde{\delta} \\
\vdots \\
0\end{array}$ & $\begin{array}{l}\frac{\infty}{0} \\
\stackrel{0}{8} \\
0\end{array}$ & $\begin{array}{l}\stackrel{+}{\mathrm{d}} \\
\stackrel{8}{8} \\
0\end{array}$ & 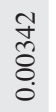 & 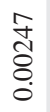 & $\begin{array}{l}\frac{2}{0} \\
\frac{8}{0} \\
0\end{array}$ & 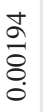 & $\frac{\mathfrak{n}}{8}$ & 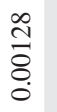 & $\begin{array}{c}\tilde{N} \\
\tilde{8} \\
0 \\
0\end{array}$ & 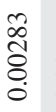 & $\stackrel{n}{\square}$ & & & $\begin{array}{l}\text { oे } \\
\text { cे } \\
0\end{array}$ & $\stackrel{n}{8}$ \\
\hline & 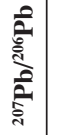 & & & & & 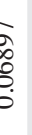 & $\underset{\infty}{\infty}$ & 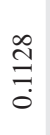 & 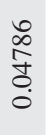 & \begin{tabular}{l}
$\widehat{y}$ \\
\multirow{y}{*}{} \\
$\stackrel{0}{0}$ \\
0
\end{tabular} & $\underset{\square}{\stackrel{J}{\Xi}}$ & 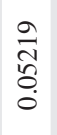 & 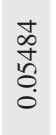 & $\begin{array}{l}\overrightarrow{\mathbb{N}} \\
\stackrel{0}{0}\end{array}$ & $\begin{array}{l}\overrightarrow{\tilde{\delta}} \\
\stackrel{\infty}{0} \\
\overrightarrow{0}\end{array}$ & 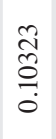 & $\begin{array}{l}0 \\
8 \\
0 \\
0 \\
0 \\
0\end{array}$ & 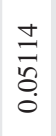 & $\frac{\vec{Y}}{\stackrel{J}{0}}$ & 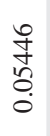 & 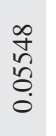 & 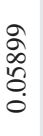 & $\begin{array}{l}\hat{\hat{t}} \\
\text { రे } \\
0 \\
0\end{array}$ & $\begin{array}{l}\frac{1}{\infty} \\
\vdots \\
\vdots \\
0 \\
0\end{array}$ & $\begin{array}{l}n \\
\infty \\
\infty \\
c \\
0 \\
0\end{array}$ & $\begin{array}{l}\stackrel{n}{\mathrm{n}} \\
\stackrel{\mathrm{m}}{=} \\
0\end{array}$ & 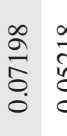 & $\begin{array}{c}\infty \\
\text { a } \\
\vdots \\
0 \\
0\end{array}$ & 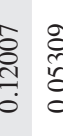 & & \\
\hline & & & 8 & & & $\frac{9}{0}$ & & શ. & $\begin{array}{l}\tilde{O} \\
\infty \\
0\end{array}$ & กี่ & $\overrightarrow{\ddot{0}}$ & $\stackrel{\infty}{0}$ & $\stackrel{?}{\stackrel{9}{0}}$ & $\underset{\text { ָे }}{\text { i }}$ & $\stackrel{\infty}{\circ}$ & $\underset{0}{0}$ & $\stackrel{5}{0}$ & $\stackrel{\infty}{\stackrel{\infty}{0}}$ & 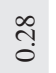 & $\stackrel{\overbrace{}}{\exists}$ & $\stackrel{\overbrace{}}{\hat{\theta}}$ & $\begin{array}{l}0 \\
\text { g. } \\
0\end{array}$ & $\tilde{3}$ & तै & $\tilde{n}$ & ָુy & & 范 & $\begin{array}{c}0 \\
0 \\
0\end{array}$ & $?$ & \\
\hline & & & & & & & & 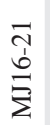 & & $\begin{array}{l}\tilde{\hat{V}} \\
\stackrel{b}{\vec{z}} \\
\vec{\Sigma}\end{array}$ & $\begin{array}{l}\stackrel{J}{N} \\
\stackrel{b}{\Sigma} \\
\stackrel{\Sigma}{\Sigma}\end{array}$ & 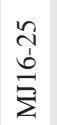 & 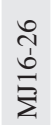 & $\begin{array}{l}\hat{\lambda} \\
\stackrel{b}{ } \\
\stackrel{\Sigma}{\Sigma}\end{array}$ & $\begin{array}{l}\text { ஸे } \\
\text { bे } \\
\stackrel{\vec{\Sigma}}{\Sigma}\end{array}$ & $\begin{array}{l}\text { ते } \\
\text { bे } \\
\stackrel{\Sigma}{\Sigma}\end{array}$ & $\begin{array}{l}\text { ह } \\
\text { b } \\
\stackrel{\Sigma}{\Sigma}\end{array}$ & $\begin{array}{l}\vec{c} \\
b \\
\vec{z}\end{array}$ & $\begin{array}{l}\tilde{\widehat{b}} \\
\text { bे } \\
\vec{\Sigma}\end{array}$ & $\begin{array}{l}\hat{n} \\
\stackrel{b}{\Sigma} \\
\vec{\Sigma}\end{array}$ & $\begin{array}{l}\text { ले } \\
\text { bे } \\
\vec{z}\end{array}$ & 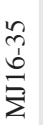 & 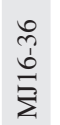 & $\begin{array}{l}\hat{n} \\
b \\
\underline{B} \\
\Sigma\end{array}$ & $\begin{array}{l}\infty \\
⿱ 亠 \\
b \\
\stackrel{\Sigma}{2}\end{array}$ & $\begin{array}{l}\text { ले } \\
\text { bे } \\
\underline{\Sigma}\end{array}$ & & & 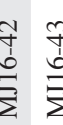 & to & \\
\hline
\end{tabular}




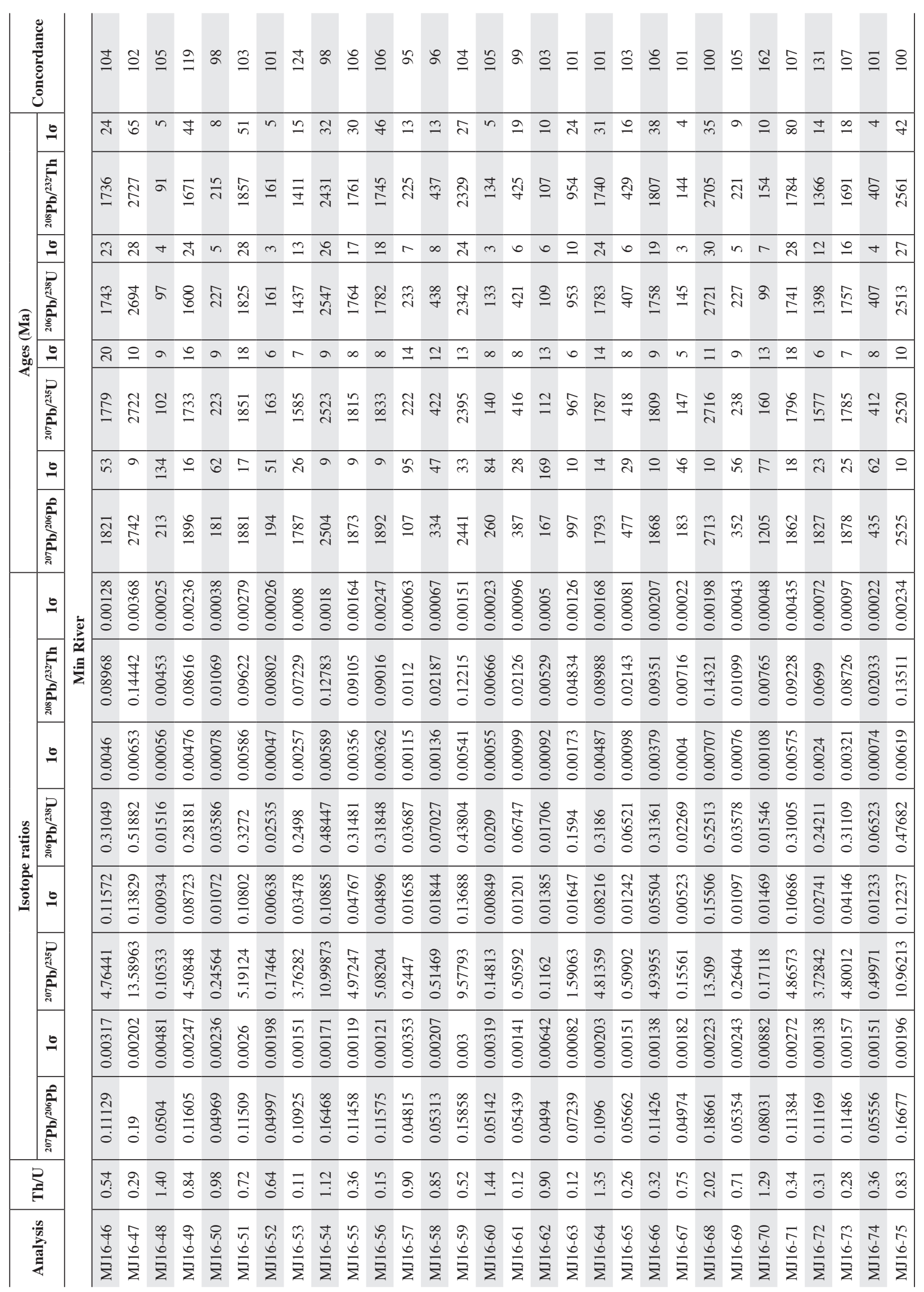




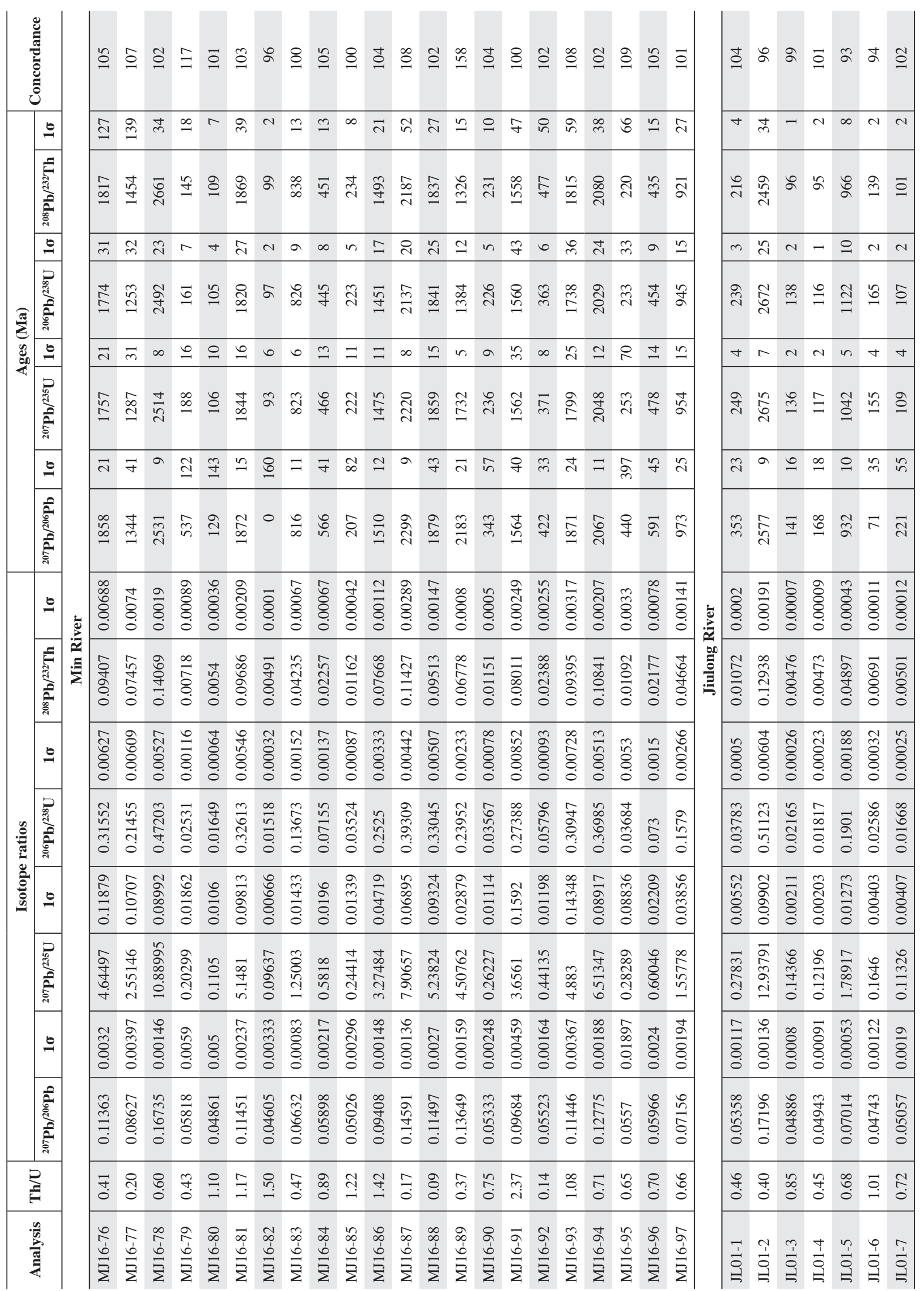




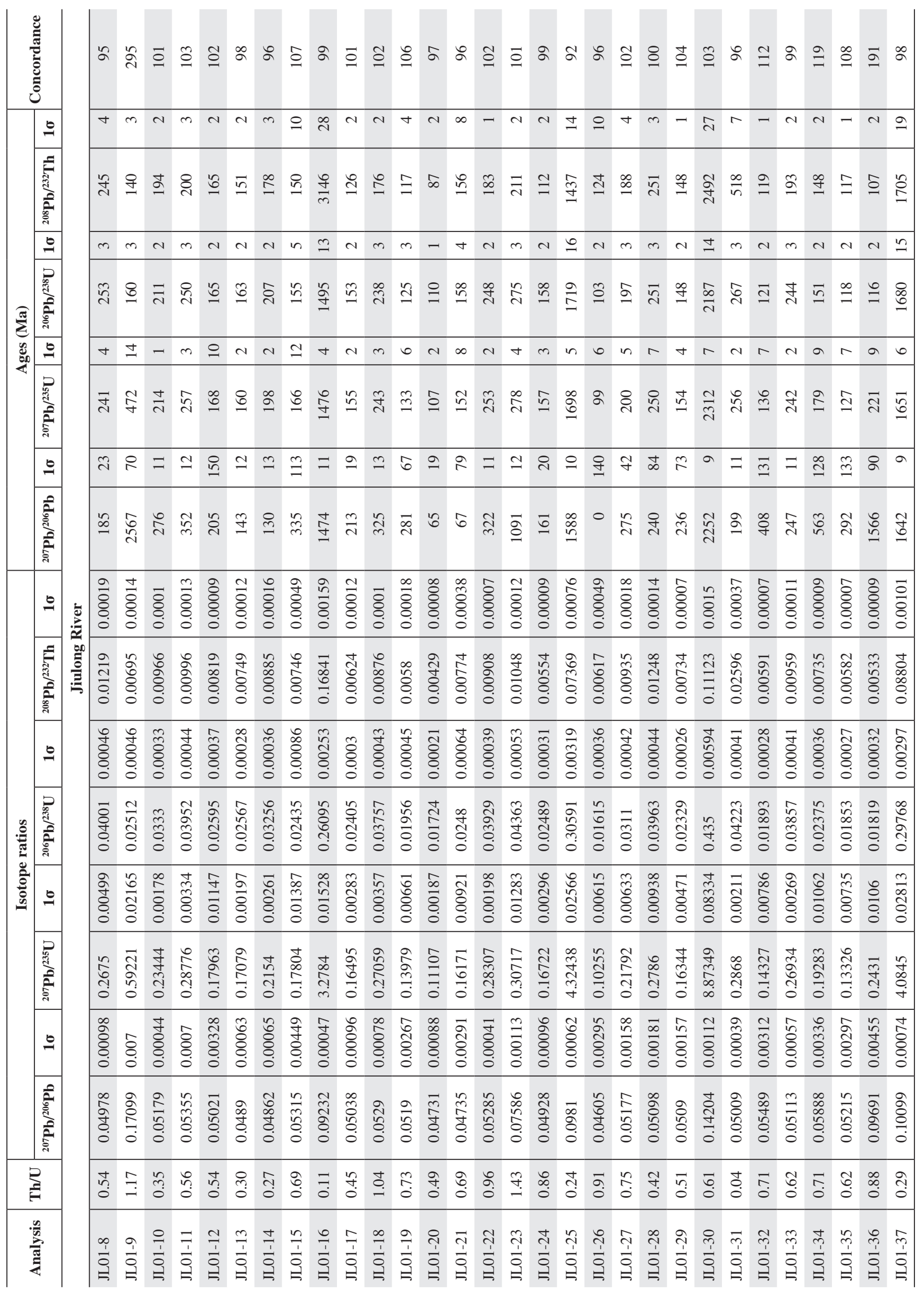




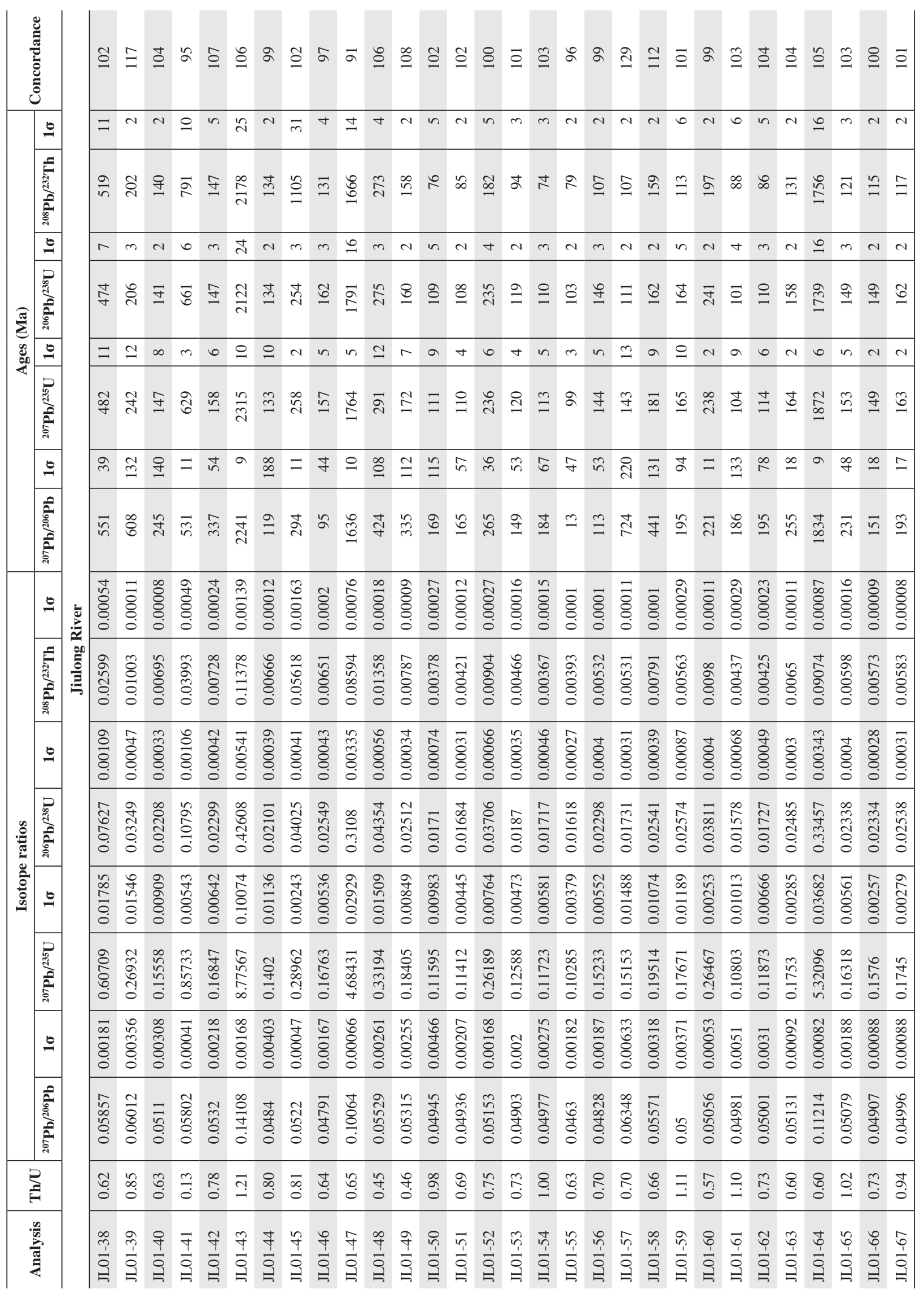




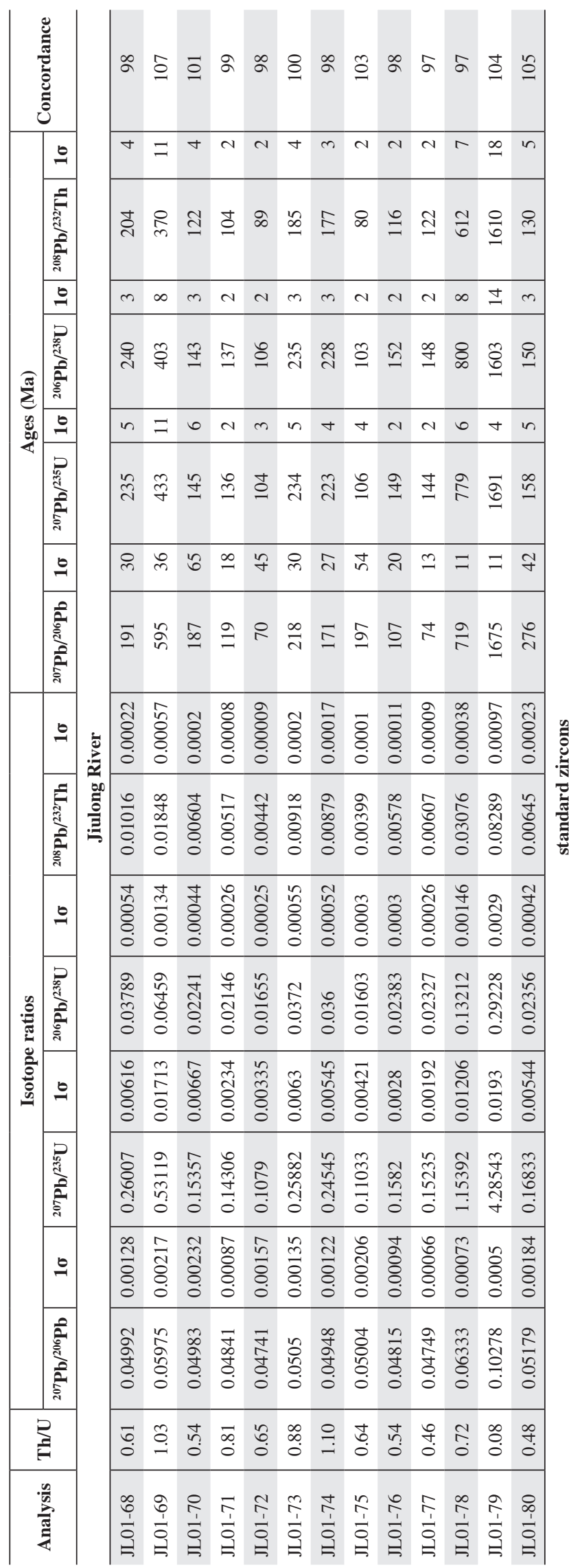

\begin{tabular}{|c|c|c|c|c|c|c|c|c|c|c|c|c|c|c|c|}
\hline$m$ & ఉా & q & $F$ & F & n & F & ले & లో & $\stackrel{\infty}{m}$ & లి & q & m & $\hat{m}$ & $\bar{F}$ & $\hat{n}$ \\
\hline ฮิ & $\stackrel{\circ}{\circ}$ & 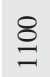 & $\bar{\Xi}$ & $\stackrel{\square}{\varnothing}$ & $\stackrel{t}{\stackrel{t}{0}}$ & 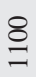 & $\stackrel{n}{\mathrm{q}}$ & 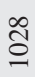 & 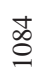 & $\stackrel{0}{0}$ & f & हิ & مْ & ôे & $\stackrel{\vec{\varrho}}{\varrho}$ \\
\hline$\Xi$ & $\stackrel{n}{2}$ & $\stackrel{0}{\circ}$ & $\underline{0}$ & $=$ & $\stackrel{n}{\sim}$ & $=$ & $\stackrel{\bullet}{\simeq}$ & $\stackrel{n}{\sim}$ & $\underline{0}$ & $?$ & 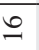 & 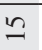 & $\cong$ & $\underline{0}$ & $\stackrel{\circ}{\circ}$ \\
\hline ๕ & ک్ర & $\stackrel{\wp}{\varrho}$ & $\tilde{\delta}$ & d़ & 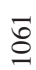 & \& & 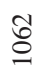 & d़ & $\stackrel{\vartheta}{\varrho}$ & $\stackrel{\mathcal{O}}{\circ}$ & ర్ర & ్ֶ & ఫ̊ & ర్ & $\widetilde{\mathscr{C}}$ \\
\hline$\underline{9}$ & 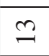 & $\stackrel{n}{-1}$ & $\stackrel{0}{0}$ & 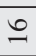 & \pm & 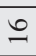 & 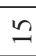 & 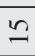 & \pm & \pm & $\underline{\bullet}$ & \pm & \pm & $\underline{0}$ & $\stackrel{n}{2}$ \\
\hline ఓ̊ & $\vec{\varnothing}$ & $\hat{\mathrm{o}}$ & $\stackrel{\tilde{s}}{0}$ & $\stackrel{\square}{\varnothing}$ & $\stackrel{+}{ \pm}$ & $\begin{array}{l}\stackrel{0}{\circ} \\
\stackrel{0}{*}\end{array}$ & 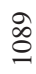 & $\hat{\varrho}$ & 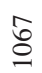 & $\underline{\underline{s}}$ & 导 & $\widehat{\widehat{s}}$ & ڤे & ڤ్ & $\stackrel{\widetilde{s}}{\subseteq}$ \\
\hline$\stackrel{2}{2}$ & $\stackrel{2}{2}$ & $\approx$ & $\underset{\text { I }}{ }$ & $\sqrt{2}$ & $\bar{\lambda}$ & $\tilde{\lambda}$ & ปี & तี & $\bar{\lambda}$ & సి & $\stackrel{\sim}{\mathrm{N}}$ & สี & $\vec{\sim}$ & ন & $\bar{\sim}$ \\
\hline હે & $\stackrel{\infty}{\circ}$ & $\stackrel{n}{=}$ & $\stackrel{\infty}{\infty}$ & 0 & $\stackrel{\infty}{\infty}$ & $\overrightarrow{\underline{m}}$ & $\stackrel{?}{g}$ & $\stackrel{\widetilde{c}}{\varrho}$ & 今ે & $\stackrel{8}{\circ}$ & ๙ & $\vec{\circ}$ & $\stackrel{\infty}{\varrho}$ & $\overrightarrow{\underline{\sigma}}$ & $\stackrel{\text { o }}{0}$ \\
\hline 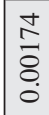 & $\frac{0}{8}$ & $\begin{array}{l}\overline{\overrightarrow{\widehat{\sigma}}} \\
\stackrel{8}{0}\end{array}$ & $\begin{array}{l}\frac{n}{\vec{\delta}} \\
\stackrel{8}{0} \\
\stackrel{0}{0}\end{array}$ & $\begin{array}{l}\text { तิ } \\
\text { ธิ }\end{array}$ & $\frac{+}{8}$ & 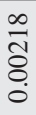 & $\begin{array}{l}\text { ठิ } \\
\text { ठิ } \\
\text {. }\end{array}$ & $\frac{\infty}{8}$ & $\frac{2}{8}$ & $\frac{\infty}{8}$ & ఫิ & $\frac{\check{\alpha}}{\tilde{8}}$ & & 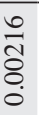 & $\frac{2}{8}$ \\
\hline స్సે & $\begin{array}{l}\hat{n} \\
\hat{\sigma}\end{array}$ & $\begin{array}{l}\overline{\hat{n}} \\
\text { है }\end{array}$ & $\begin{array}{l}\infty \\
\infty \\
\tilde{n}_{0}\end{array}$ & $\begin{array}{l}\infty \\
\infty \\
\bigcap \\
n\end{array}$ & 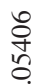 & ถิ & 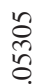 & ธี & 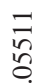 & f) & $\begin{array}{l}\text { ते } \\
\text { है }\end{array}$ & હૂ & 势 & $\begin{array}{l}\hat{\tilde{n}} \\
\hat{n}\end{array}$ & బิ \\
\hline 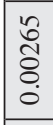 & 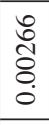 & $\begin{array}{l}\text { ڤે } \\
\text { ठ઼. } \\
\text {. }\end{array}$ & $\begin{array}{l}\overrightarrow{0} \\
\stackrel{8}{0} \\
\stackrel{0}{\circ}\end{array}$ & ठ્లి & ठّ̊ & 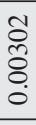 & 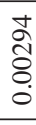 & 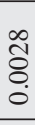 & $\begin{array}{l}\text { के } \\
\text { ठे } \\
\text { ठे. }\end{array}$ & 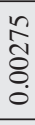 & ڤે & 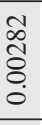 & 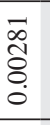 & §̊. & 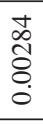 \\
\hline 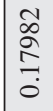 & \begin{tabular}{l}
\multirow{2}{\circ}{} \\
$\stackrel{1}{0}$
\end{tabular} & $\begin{array}{l}8 \\
\stackrel{0}{\circ} \\
\vdots \\
0\end{array}$ & 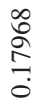 & \& & ઠे & ปે & ఫે & సี & 离 & ఫี & 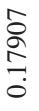 & $\begin{array}{l}\stackrel{\circ}{2} \\
\stackrel{2}{0} \\
0\end{array}$ & 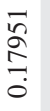 & 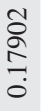 & $\stackrel{2}{\stackrel{0}{0}}$ \\
\hline $\begin{array}{l}\text { पू } \\
\text { है } \\
\text { है. }\end{array}$ & $\begin{array}{l}\stackrel{0}{2} \\
\hat{0} \\
\stackrel{0}{0}\end{array}$ & 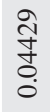 & \begin{tabular}{l}
$n$ \\
\multirow{0}{0}{} \\
0 \\
0 \\
0
\end{tabular} & \& & ఏ్ & $\frac{\infty}{5}$ & 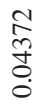 & 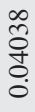 & 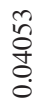 & $\begin{array}{l}\widetilde{\alpha} \\
\infty \\
\tilde{\sigma}\end{array}$ & 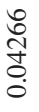 & 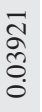 & 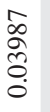 & 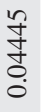 & $\begin{array}{l}\frac{\hat{\sigma}}{\sigma} \\
\stackrel{0}{0} \\
\stackrel{0}{0}\end{array}$ \\
\hline 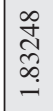 & $\begin{array}{l}\infty \\
\stackrel{\infty}{*} \\
\stackrel{\infty}{-}\end{array}$ & 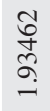 & 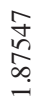 & 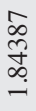 & हू & $\underset{c}{0}$ & $\frac{\widetilde{N}}{\mathrm{~N}}$ & స్ & 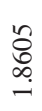 & $\stackrel{\text { }}{\stackrel{\infty}{\infty}}$ & $\stackrel{\infty}{\infty}$ & 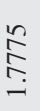 & 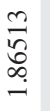 & 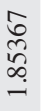 & $\underset{\substack{\mathfrak{a} \\
\stackrel{a}{\infty}}}{ }$ \\
\hline $\begin{array}{l}\frac{n}{8} \\
\frac{8}{0} \\
\text {. }\end{array}$ & 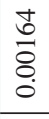 & $\frac{\circ}{\circ}$ & $\begin{array}{l}\stackrel{\infty}{\circ} \\
\stackrel{\vec{\sigma}}{0} \\
\stackrel{0}{0}\end{array}$ & ڤ్రి & 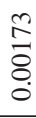 & ठิ & 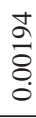 & $\stackrel{ }{8}$ & $\begin{array}{l}\frac{2}{8} \\
\frac{0}{0}\end{array}$ & $\frac{\pi}{\frac{\pi}{8}}$ & $\stackrel{\infty}{\infty}$ & $\frac{0}{8}$ & $\begin{array}{l}\frac{0}{0} \\
\frac{1}{8} \\
0 \\
0\end{array}$ & 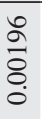 & $\frac{\infty}{\stackrel{\infty}{8}}$ \\
\hline $\begin{array}{c}\text { ले } \\
\text { है } \\
\text { o. }\end{array}$ & 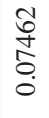 & $\begin{array}{l}\bar{\nabla} \\
\stackrel{\infty}{0} \\
0 \\
0\end{array}$ & $\begin{array}{l}\vec{r} \\
\text { s. } \\
\text { o. } \\
0\end{array}$ & & & - & & 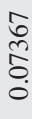 & $\begin{array}{l}\vec{n} \\
\stackrel{n}{o} \\
\stackrel{0}{0}\end{array}$ & $\begin{array}{ll}\infty \\
20\end{array}$ & $\mathfrak{\Xi}$ & $\begin{array}{c}\bar{\infty} \\
\stackrel{\infty}{\sigma} \\
0 \\
0\end{array}$ & $\begin{array}{l}\hat{a} \\
\hat{n} \\
\vdots \\
0 \\
0\end{array}$ & $\begin{array}{l}\bar{n} \\
\stackrel{n}{n} \\
\vdots \\
0\end{array}$ & $\begin{array}{l}\text { oे } \\
\text { مे } \\
0 \\
0\end{array}$ \\
\hline $\begin{array}{l}\stackrel{\infty}{\stackrel{d}{i}} \\
\stackrel{d}{i}\end{array}$ & $\begin{array}{l}\text { o } \\
\text { d } \\
i\end{array}$ & 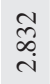 & 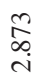 & \pm & \&े & $\stackrel{7}{\infty}$ & Бิ & $\begin{array}{c}\infty \\
\infty \\
\infty\end{array}$ & 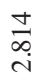 & ふু & $\infty$ & 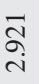 & $\begin{array}{l}\stackrel{\infty}{\infty} \\
\text { i }\end{array}$ & 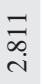 & 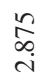 \\
\hline $\begin{array}{l}\frac{8}{n} \\
\frac{n}{a}\end{array}$ & $\begin{array}{l}\frac{8}{0} \\
\frac{n}{\alpha}\end{array}$ & $\frac{8}{10}$ & $\begin{array}{l}8 \\
\frac{n}{2}\end{array}$ & & & $n$ & & & $\begin{array}{l}8 \\
\text { na } \\
a\end{array}$ & & & $\frac{8}{n}$ & $\begin{array}{l}8 \\
\text { ha } \\
\frac{1}{2}\end{array}$ & $\frac{8}{n}$ & $\begin{array}{l}8 \\
\frac{n}{\sigma}\end{array}$ \\
\hline
\end{tabular}




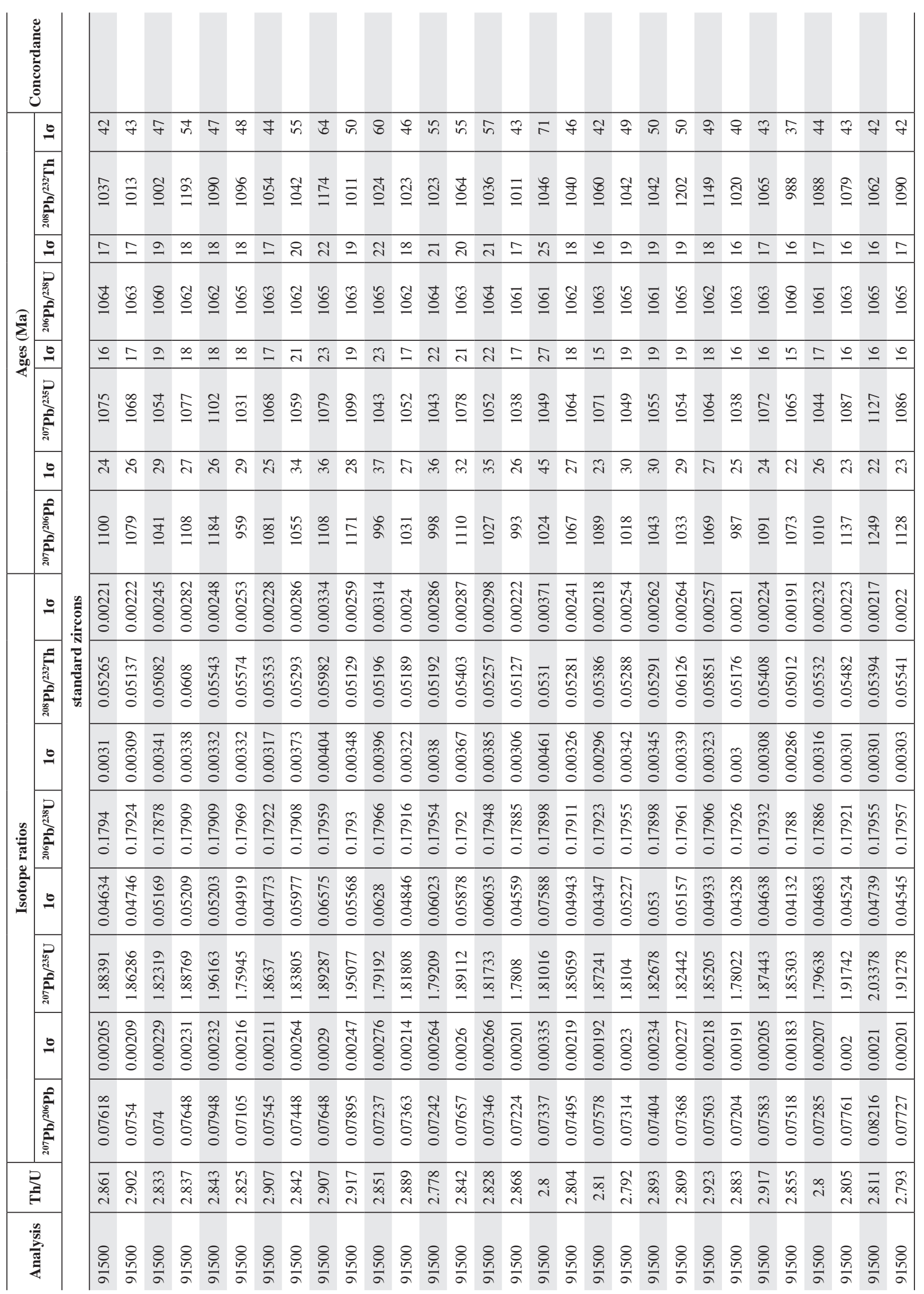




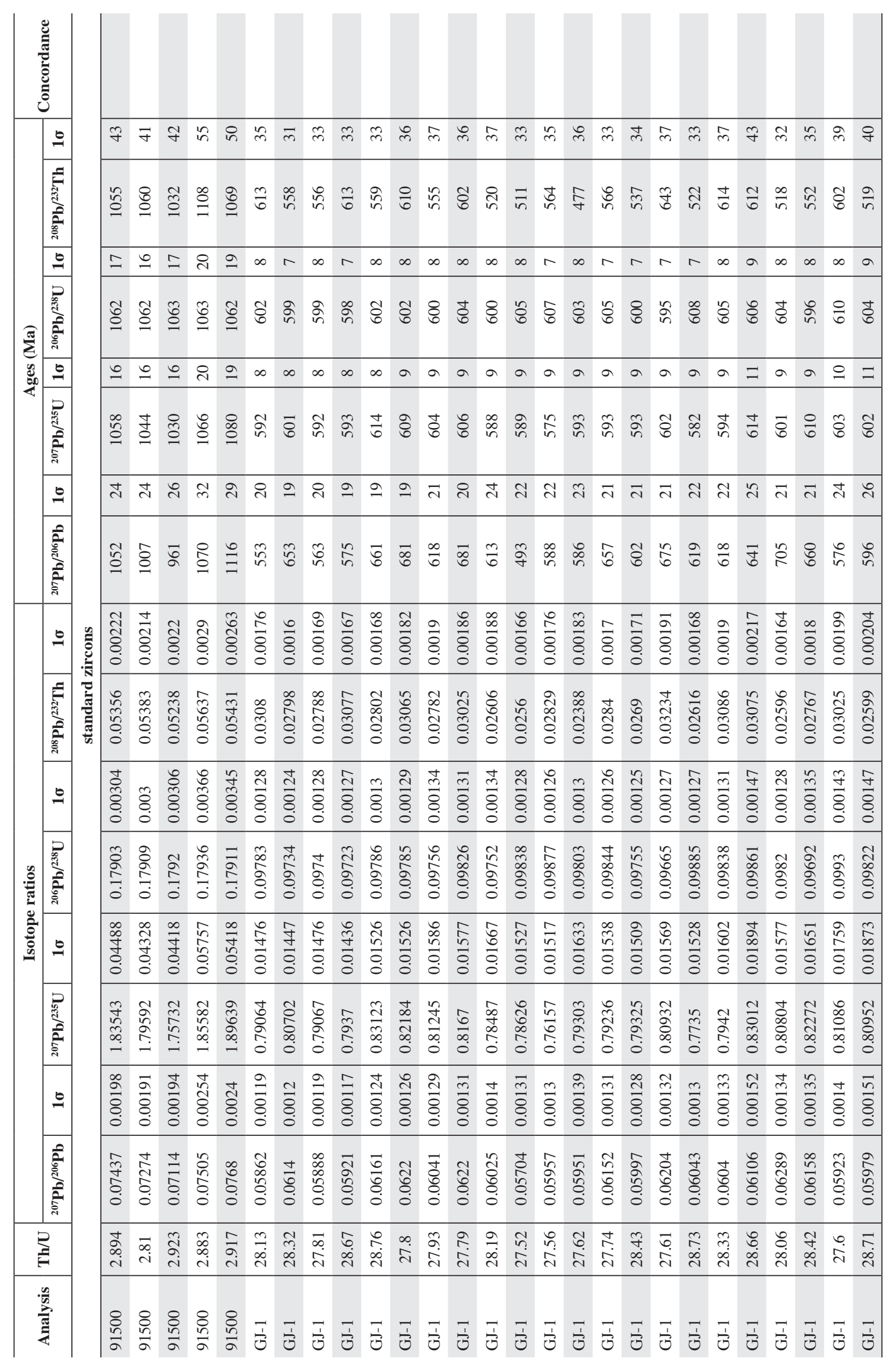


APPENDIX 2

Hf isotope data for detrital zircons from Min River and Jiulong River.

\begin{tabular}{|c|c|c|c|c|c|c|c|c|c|}
\hline Analysis & Age (Ma) & ${ }^{176} \mathrm{Yb} /{ }^{177} \mathbf{H f}$ & $2 \sigma$ & ${ }^{176} \mathbf{L u} /{ }^{177} \mathbf{H f}$ & $2 \sigma$ & ${ }^{176} \mathbf{H f} /{ }^{177} \mathbf{H f}$ & $2 \sigma$ & $\varepsilon_{\mathrm{Hf}}(\mathrm{t})$ & $\mathbf{T}_{\mathrm{DM} 2}$ \\
\hline \multicolumn{10}{|c|}{ Min River } \\
\hline MJ01-1 & 140 & 0.030061 & 0.000802 & 0.000967 & 0.000024 & 0.282223 & 0.000009 & -16.9 & 2220 \\
\hline MJ01-2 & 229 & 0.022822 & 0.000021 & 0.000698 & 0.000002 & 0.282448 & 0.000010 & -6.9 & 1668 \\
\hline MJ01-3 & 158 & 0.256246 & 0.000262 & 0.007430 & 0.000010 & 0.282429 & 0.000014 & -9.9 & 1798 \\
\hline MJ01-5 & 457 & 0.038297 & 0.000830 & 0.001204 & 0.000022 & 0.282316 & 0.000018 & -6.8 & 1836 \\
\hline MJ01-7 & 471 & 0.022218 & 0.000160 & 0.000922 & 0.000008 & 0.282592 & 0.000016 & 3.4 & 1208 \\
\hline MJ01-8 & 97 & 0.029338 & 0.000092 & 0.000918 & 0.000005 & 0.282715 & 0.000013 & -0.4 & 1153 \\
\hline MJ01-9 & 151 & 0.156739 & 0.002176 & 0.004993 & 0.000070 & 0.282397 & 0.000013 & -10.9 & 1836 \\
\hline MJ01-12 & 139 & 0.035523 & 0.000168 & 0.001095 & 0.000007 & 0.282429 & 0.000013 & -9.6 & 1766 \\
\hline MJ01-13 & 243 & 0.027156 & 0.000988 & 0.000839 & 0.000030 & 0.282542 & 0.000013 & -3.3 & 1462 \\
\hline MJ01-15 & 895 & 0.051039 & 0.001503 & 0.001618 & 0.000047 & 0.282129 & 0.000013 & -4.1 & 1973 \\
\hline MJ01-16 & 2311 & 0.018007 & 0.000766 & 0.000602 & 0.000026 & 0.281278 & 0.000013 & -1.9 & 2991 \\
\hline MJ01-17 & 369 & 0.023228 & 0.000198 & 0.000756 & 0.000007 & 0.282407 & 0.000011 & -5.4 & 1685 \\
\hline MJ01-18 & 409 & 0.036025 & 0.000300 & 0.001192 & 0.000008 & 0.282230 & 0.000013 & -10.9 & 2064 \\
\hline MJ01-20 & 417 & 0.025427 & 0.000206 & 0.000774 & 0.000006 & 0.282376 & 0.000011 & -5.4 & 1719 \\
\hline MJ01-23 & 419 & 0.052249 & 0.000577 & 0.001727 & 0.000020 & 0.282303 & 0.000015 & -8.2 & 1874 \\
\hline MJ01-24 & 1862 & 0.017808 & 0.000223 & 0.000548 & 0.000005 & 0.281642 & 0.000012 & 0.9 & 2440 \\
\hline MJ01-25 & 2497 & 0.011364 & 0.000280 & 0.000371 & 0.000006 & 0.280856 & 0.000010 & -12.2 & 4021 \\
\hline MJ01-26 & 139 & 0.109775 & 0.000487 & 0.003077 & 0.000018 & 0.282514 & 0.000014 & -6.8 & 1580 \\
\hline MJ01-27 & 173 & 0.043156 & 0.001489 & 0.001380 & 0.000042 & 0.282237 & 0.000013 & -15.7 & 2193 \\
\hline MJ01-29 & 251 & 0.032370 & 0.000219 & 0.000987 & 0.000007 & 0.282412 & 0.000015 & -7.8 & 1761 \\
\hline MJ01-30 & 919 & 0.102275 & 0.001917 & 0.003141 & 0.000051 & 0.282326 & 0.000016 & 2.4 & 1520 \\
\hline MJ01-31 & 1808 & 0.017626 & 0.000059 & 0.000525 & 0.000001 & 0.281464 & 0.000009 & -6.6 & 2902 \\
\hline MJ01-32 & 483 & 0.001242 & 0.000111 & 0.000033 & 0.000004 & 0.282110 & 0.000011 & -13.1 & 2269 \\
\hline MJ01-33 & 102 & 0.028703 & 0.000100 & 0.000904 & 0.000002 & 0.282500 & 0.000011 & -7.9 & 1630 \\
\hline MJ01-34 & 149 & 0.031076 & 0.000355 & 0.001037 & 0.000011 & 0.282290 & 0.000010 & -14.3 & 2064 \\
\hline MJ01-35 & 446 & 0.014731 & 0.000012 & 0.000462 & 0.000001 & 0.282303 & 0.000011 & -7.3 & 1895 \\
\hline MJ01-36 & 153 & 0.078064 & 0.000559 & 0.002497 & 0.000014 & 0.282433 & 0.000015 & -9.3 & 1749 \\
\hline MJ01-41 & 182 & 0.020796 & 0.000165 & 0.000721 & 0.000004 & 0.282076 & 0.000011 & -21.1 & 2517 \\
\hline MJ01-42 & 147 & 0.029669 & 0.000634 & 0.000947 & 0.000016 & 0.282323 & 0.000011 & -13.2 & 2014 \\
\hline MJ01-43 & 425 & 0.118893 & 0.001316 & 0.003882 & 0.000067 & 0.282400 & 0.000013 & -5.3 & 1666 \\
\hline MJ01-44 & 498 & 0.032259 & 0.000352 & 0.001040 & 0.000013 & 0.282333 & 0.000013 & -5.2 & 1755 \\
\hline MJ01-45 & 2387 & 0.006626 & 0.000137 & 0.000237 & 0.000004 & 0.281294 & 0.000012 & 1.1 & 2904 \\
\hline MJ01-46 & 231 & 0.022474 & 0.000030 & 0.000693 & 0.000001 & 0.282361 & 0.000009 & -10.0 & 1906 \\
\hline MJ01-47 & 259 & 0.023813 & 0.000078 & 0.000610 & 0.000004 & 0.282364 & 0.000013 & -9.2 & 1838 \\
\hline MJ01-48 & 465 & 0.027163 & 0.000161 & 0.000821 & 0.000002 & 0.282313 & 0.000011 & -6.6 & 1824 \\
\hline MJ01-49 & 403 & 0.017166 & 0.000056 & 0.000541 & 0.000001 & 0.282286 & 0.000010 & -8.8 & 1934 \\
\hline MJ01-50 & 814 & 0.039370 & 0.000295 & 0.001223 & 0.000009 & 0.282136 & 0.000015 & -5.4 & 2012 \\
\hline MJ01-51 & 874 & 0.028858 & 0.000146 & 0.000770 & 0.000007 & 0.282171 & 0.000012 & -2.6 & 1927 \\
\hline MJ01-52 & 428 & 0.028158 & 0.000518 & 0.000903 & 0.000014 & 0.282213 & 0.000011 & -11.0 & 2082 \\
\hline MJ01-53 & 466 & 0.050020 & 0.001818 & 0.001497 & 0.000053 & 0.282445 & 0.000013 & -2.1 & 1544 \\
\hline MJ01-54 & 1758 & 0.045828 & 0.000305 & 0.001361 & 0.000009 & 0.281558 & 0.000009 & -5.4 & 2676 \\
\hline MJ01-55 & 153 & 0.037357 & 0.000241 & 0.001199 & 0.000008 & 0.282340 & 0.000012 & -12.5 & 1954 \\
\hline MJ01-56 & 1774 & 0.008286 & 0.000076 & 0.000224 & 0.000001 & 0.281550 & 0.000011 & -3.9 & 2829 \\
\hline
\end{tabular}




\begin{tabular}{|c|c|c|c|c|c|c|c|c|c|}
\hline Analysis & Age (Ma) & ${ }^{176} \mathbf{Y b} /{ }^{177} \mathbf{H f}$ & $2 \sigma$ & ${ }^{176} \mathbf{L u} /{ }^{177} \mathbf{H f}$ & $2 \sigma$ & ${ }^{176} \mathbf{H f} /{ }^{177} \mathbf{H f}$ & $2 \sigma$ & $\varepsilon_{\mathrm{Hf}}(\mathrm{t})$ & $\mathbf{T}_{\mathrm{DM} 2}$ \\
\hline \multicolumn{10}{|c|}{ Min River } \\
\hline MJ01-57 & 1832 & 0.022120 & 0.000248 & 0.000672 & 0.000006 & 0.281611 & 0.000011 & -1.0 & 2584 \\
\hline MJ01-58 & 1740 & 0.010120 & 0.000129 & 0.000315 & 0.000005 & 0.281608 & 0.000013 & -2.8 & 2737 \\
\hline MJ01-59 & 613 & 0.040483 & 0.001270 & 0.001133 & 0.000037 & 0.282403 & 0.000013 & -0.3 & 1541 \\
\hline MJ01-60 & 466 & 0.080449 & 0.000575 & 0.002434 & 0.000022 & 0.282301 & 0.000012 & -7.5 & 1860 \\
\hline MJ01-61 & 2363 & 0.017519 & 0.000101 & 0.000568 & 0.000003 & 0.281212 & 0.000009 & -3.0 & 3205 \\
\hline MJ01-62 & 163 & 0.320117 & 0.001768 & 0.010241 & 0.000061 & 0.282762 & 0.000019 & 1.7 & 1013 \\
\hline MJ01-63 & 155 & 0.056064 & 0.000853 & 0.001801 & 0.000028 & 0.282308 & 0.000013 & -13.6 & 2024 \\
\hline MJ01-64 & 447 & 0.018369 & 0.000131 & 0.000545 & 0.000005 & 0.282401 & 0.000011 & -3.8 & 1678 \\
\hline MJ01-65 & 139 & 0.076933 & 0.003620 & 0.002590 & 0.000123 & 0.282633 & 0.000016 & -2.5 & 1313 \\
\hline MJ01-66 & 144 & 0.038104 & 0.000523 & 0.001207 & 0.000015 & 0.282450 & 0.000014 & -8.7 & 1713 \\
\hline MJ01-67 & 146 & 0.035743 & 0.001705 & 0.001084 & 0.000050 & 0.282320 & 0.000015 & -13.3 & 2000 \\
\hline MJ01-68 & 429 & 0.015514 & 0.000072 & 0.000465 & 0.000002 & 0.282337 & 0.000016 & -6.4 & 1800 \\
\hline MJ01-69 & 2316 & 0.010870 & 0.000233 & 0.000319 & 0.000006 & 0.281348 & 0.000013 & 1.2 & 2825 \\
\hline MJ01-70 & 107 & 0.019469 & 0.000194 & 0.000592 & 0.000004 & 0.282513 & 0.000013 & -7.3 & 1598 \\
\hline MJ01-71 & 1574 & 0.022870 & 0.000795 & 0.000638 & 0.000019 & 0.281460 & 0.000016 & -12.1 & 3067 \\
\hline MJ01-73 & 229 & 0.045479 & 0.000655 & 0.001316 & 0.000022 & 0.282364 & 0.000013 & -10.0 & 1851 \\
\hline MJ01-74 & 1684 & 0.012102 & 0.000225 & 0.000323 & 0.000005 & 0.281448 & 0.000011 & -9.7 & 3053 \\
\hline MJ01-76 & 492 & 0.051406 & 0.001225 & 0.001536 & 0.000038 & 0.282284 & 0.000014 & -7.3 & 1862 \\
\hline MJ01-77 & 2089 & 0.001655 & 0.000009 & 0.000044 & 0.000000 & 0.281332 & 0.000012 & -4.2 & 3060 \\
\hline MJ01-78 & 117 & 0.042729 & 0.000546 & 0.001370 & 0.000019 & 0.282517 & 0.000015 & -7.0 & 1582 \\
\hline MJ01-79 & 102 & 0.015853 & 0.000277 & 0.000459 & 0.000008 & 0.282653 & 0.000014 & -2.4 & 1288 \\
\hline MJ01-80 & 137 & 0.022651 & 0.000317 & 0.000741 & 0.000012 & 0.282430 & 0.000013 & -9.6 & 1762 \\
\hline MJ01-81 & 371 & 0.012421 & 0.000172 & 0.000292 & 0.000006 & 0.282273 & 0.000011 & -9.9 & 1980 \\
\hline MJ01-82 & 419 & 0.040933 & 0.000302 & 0.001192 & 0.000011 & 0.282342 & 0.000014 & -6.7 & 1786 \\
\hline MJ01-83 & 2506 & 0.013330 & 0.000063 & 0.000418 & 0.000002 & 0.281046 & 0.000011 & -5.3 & 3299 \\
\hline MJ01-84 & 1672 & 0.000627 & 0.000010 & 0.000016 & 0.000000 & 0.281585 & 0.000010 & -4.8 & 2656 \\
\hline MJ01-85 & 1664 & 0.000837 & 0.000010 & 0.000021 & 0.000000 & 0.281364 & 0.000010 & -12.8 & 3171 \\
\hline MJ01-86 & 240 & 0.014052 & 0.000194 & 0.000464 & 0.000005 & 0.282443 & 0.000016 & -6.8 & 1679 \\
\hline MJ01-87 & 103 & 0.041433 & 0.000230 & 0.001272 & 0.000004 & 0.282589 & 0.000017 & -4.7 & 1432 \\
\hline MJ01-88 & 426 & 0.027080 & 0.000166 & 0.000902 & 0.000007 & 0.282506 & 0.000015 & -0.6 & 1425 \\
\hline MJ01-89 & 224 & 0.028151 & 0.000755 & 0.000887 & 0.000020 & 0.282413 & 0.000018 & -8.3 & 1746 \\
\hline MJ01-90 & 1621 & 0.009423 & 0.000061 & 0.000299 & 0.000003 & 0.281411 & 0.000014 & -12.4 & 3128 \\
\hline MJ01-91 & 100 & 0.030247 & 0.000210 & 0.000962 & 0.000004 & 0.282756 & 0.000017 & 1.1 & 1061 \\
\hline MJ01-92 & 358 & 0.028265 & 0.000114 & 0.000911 & 0.000002 & 0.282523 & 0.000012 & -1.5 & 1429 \\
\hline MJ01-93 & 393 & 0.027227 & 0.000277 & 0.000872 & 0.000007 & 0.282460 & 0.000015 & -3.0 & 1543 \\
\hline MJ01-94 & 395 & 0.018386 & 0.000036 & 0.000569 & 0.000000 & 0.282361 & 0.000012 & -6.3 & 1771 \\
\hline MJ01-95 & 404 & 0.039277 & 0.000103 & 0.001207 & 0.000005 & 0.282362 & 0.000011 & -6.3 & 1763 \\
\hline MJ01-96 & 410 & 0.037372 & 0.000199 & 0.001173 & 0.000004 & 0.282279 & 0.000011 & -9.1 & 1935 \\
\hline MJ01-97 & 1742 & 0.022556 & 0.000376 & 0.000669 & 0.000009 & 0.281467 & 0.000013 & -8.1 & 2895 \\
\hline MJ01-98 & 2336 & 0.011417 & 0.000120 & 0.000372 & 0.000002 & 0.281117 & 0.000012 & -6.7 & 3361 \\
\hline MJ01-99 & 98 & 0.034012 & 0.000126 & 0.001135 & 0.000005 & 0.282513 & 0.000014 & -7.5 & 1606 \\
\hline MJ01-100 & 351 & 0.047334 & 0.000447 & 0.001370 & 0.000010 & 0.282557 & 0.000014 & -0.6 & 1350 \\
\hline MJ01-101 & 1762 & 0.011824 & 0.000100 & 0.000353 & 0.000003 & 0.281446 & 0.000013 & -8.1 & 2960 \\
\hline MJ01-102 & 426 & 0.021909 & 0.000251 & 0.000808 & 0.000008 & 0.282286 & 0.000013 & -8.4 & 1927 \\
\hline MJ01-103 & 398 & 0.043372 & 0.000253 & 0.001591 & 0.000011 & 0.282348 & 0.000014 & -7.0 & 1786 \\
\hline
\end{tabular}




\begin{tabular}{|c|c|c|c|c|c|c|c|c|c|}
\hline Analysis & Age (Ma) & ${ }^{176} \mathbf{Y b} /{ }^{177} \mathbf{H f}$ & $2 \sigma$ & ${ }^{176} \mathrm{Lu} /{ }^{177} \mathbf{H f}$ & $2 \sigma$ & ${ }^{176} \mathrm{Hf} /{ }^{177} \mathrm{Hf}$ & $2 \sigma$ & $\varepsilon_{\mathrm{Hf}}(\mathrm{t})$ & $\mathbf{T}_{\mathrm{DM} 2}$ \\
\hline \multicolumn{10}{|c|}{ Min River } \\
\hline MJ01-105 & 181 & 0.012533 & 0.000231 & 0.000448 & 0.000007 & 0.282142 & 0.000012 & -18.8 & 2370 \\
\hline MJ01-106 & 1715 & 0.009727 & 0.000021 & 0.000271 & 0.000000 & 0.281505 & 0.000013 & -6.9 & 2821 \\
\hline MJ01-107 & 151 & 0.181106 & 0.003046 & 0.005696 & 0.000101 & 0.282356 & 0.000019 & -12.4 & 1951 \\
\hline MJ01-108 & 154 & 0.023769 & 0.000271 & 0.000776 & 0.000008 & 0.282425 & 0.000015 & -9.4 & 1765 \\
\hline MJ01-109 & 420 & 0.020490 & 0.000159 & 0.000770 & 0.000005 & 0.282379 & 0.000018 & -5.2 & 1710 \\
\hline MJ01-110 & 136 & 0.017338 & 0.000255 & 0.000572 & 0.000007 & 0.282137 & 0.000016 & -20.0 & 2409 \\
\hline MJ01-111 & 1414 & 0.011133 & 0.000074 & 0.000349 & 0.000003 & 0.281587 & 0.000017 & -10.9 & 2833 \\
\hline MJ01-112 & 137 & 0.034510 & 0.000436 & 0.001159 & 0.000011 & 0.282445 & 0.000018 & -9.1 & 1732 \\
\hline MJ01-113 & 429 & 0.030272 & 0.000124 & 0.000972 & 0.000004 & 0.282359 & 0.000016 & -5.8 & 1753 \\
\hline MJ01-114 & 1679 & 0.016953 & 0.000075 & 0.000524 & 0.000003 & 0.281471 & 0.000013 & -9.3 & 2936 \\
\hline MJ01-115 & 1690 & 0.006885 & 0.000392 & 0.000201 & 0.000012 & 0.281456 & 0.000013 & -9.2 & 2938 \\
\hline MJ01-117 & 1727 & 0.013308 & 0.000016 & 0.000410 & 0.000001 & 0.281503 & 0.000016 & -6.9 & 2828 \\
\hline MJ01-118 & 146 & 0.041588 & 0.000293 & 0.001373 & 0.000007 & 0.282298 & 0.000019 & -14.1 & 2054 \\
\hline MJ01-119 & 2356 & 0.013068 & 0.000036 & 0.000379 & 0.000001 & 0.281041 & 0.000013 & -8.9 & 3439 \\
\hline MJ01-120 & 422 & 0.014963 & 0.000043 & 0.000451 & 0.000001 & 0.282299 & 0.000013 & -7.9 & 1881 \\
\hline MJ01-121 & 374 & 0.024260 & 0.000597 & 0.000742 & 0.000019 & 0.282400 & 0.000013 & -5.5 & 1690 \\
\hline MJ01-122 & 1646 & 0.030688 & 0.000272 & 0.000877 & 0.000009 & 0.281414 & 0.000014 & -12.4 & 3102 \\
\hline MJ01-123 & 1443 & 0.024646 & 0.000118 & 0.000697 & 0.000002 & 0.281485 & 0.000013 & -14.3 & 3057 \\
\hline MJ01-124 & 758 & 0.012959 & 0.000031 & 0.000396 & 0.000002 & 0.282233 & 0.000014 & -2.8 & 1820 \\
\hline MJ01-125 & 145 & 0.031481 & 0.000245 & 0.000983 & 0.000005 & 0.282289 & 0.000015 & -14.4 & 2071 \\
\hline MJ01-126 & 106 & 0.047722 & 0.000578 & 0.001448 & 0.000019 & 0.282563 & 0.000016 & -5.6 & 1491 \\
\hline MJ01-129 & 478 & 0.030609 & 0.000156 & 0.000951 & 0.000003 & 0.282816 & 0.000015 & 11.5 & 700 \\
\hline MJ01-130 & 249 & 0.013671 & 0.000306 & 0.000447 & 0.000010 & 0.282347 & 0.000014 & -10.0 & 1878 \\
\hline MJ01-131 & 162 & 0.035350 & 0.000187 & 0.001192 & 0.000007 & 0.282348 & 0.000014 & -12.0 & 1934 \\
\hline MJ01-132 & 472 & 0.044008 & 0.000905 & 0.001311 & 0.000026 & 0.282385 & 0.000016 & -4.0 & 1675 \\
\hline MJ01-133 & 1803 & 0.021494 & 0.000133 & 0.000627 & 0.000004 & 0.281453 & 0.000015 & -7.2 & 2907 \\
\hline MJ01-134 & 840 & 0.013196 & 0.000120 & 0.000406 & 0.000003 & 0.282006 & 0.000014 & -9.0 & 2271 \\
\hline MJ01-135 & 2765 & 0.030582 & 0.000301 & 0.000925 & 0.000010 & 0.281095 & 0.000016 & 1.4 & 3134 \\
\hline MJ01-136 & 664 & 0.020173 & 0.000431 & 0.000665 & 0.000013 & 0.281972 & 0.000021 & -14.2 & 2459 \\
\hline MJ01-137 & 1759 & 0.022184 & 0.000135 & 0.000692 & 0.000003 & 0.281523 & 0.000013 & -5.8 & 2785 \\
\hline MJ01-138 & 714 & 0.042057 & 0.001101 & 0.001217 & 0.000026 & 0.282306 & 0.000016 & -1.6 & 1711 \\
\hline MJ01-139 & 1602 & 0.006238 & 0.000281 & 0.000163 & 0.000009 & 0.281462 & 0.000013 & -10.9 & 2978 \\
\hline MJ01-140 & 1102 & 0.018323 & 0.000098 & 0.000584 & 0.000004 & 0.281584 & 0.000014 & -18.2 & 3039 \\
\hline MJ01-141 & 1500 & 0.015311 & 0.000040 & 0.000469 & 0.000000 & 0.281460 & 0.000012 & -13.6 & 3064 \\
\hline MJ01-142 & 677 & 0.028306 & 0.000606 & 0.000969 & 0.000020 & 0.282044 & 0.000012 & -11.5 & 2302 \\
\hline MJ01-143 & 104 & 0.033591 & 0.000770 & 0.001058 & 0.000021 & 0.282590 & 0.000014 & -4.7 & 1429 \\
\hline MJ01-144 & 237 & 0.022534 & 0.000059 & 0.000713 & 0.000001 & 0.282436 & 0.000014 & -7.2 & 1690 \\
\hline MJ01-145 & 1992 & 0.010032 & 0.000891 & 0.000361 & 0.000033 & 0.281364 & 0.000014 & -5.7 & 2964 \\
\hline MJ01-146 & 1742 & 0.014127 & 0.000327 & 0.000426 & 0.000009 & 0.281442 & 0.000014 & -8.8 & 2953 \\
\hline & 170 & 0.034202 & 0.000366 & 0.001048 & 0.000010 & 0.282361 & 0.000011 & -11.3 & 1899 \\
\hline MJ16-03 & 388 & 0.067393 & 0.000247 & 0.001965 & 0.000004 & 0.282395 & 0.000029 & -5.7 & 1713 \\
\hline MJ16-04 & 1857 & 0.019431 & 0.000276 & 0.000482 & 0.000009 & 0.281340 & 0.000017 & -9.8 & 3107 \\
\hline MJ16-05 & 145 & 0.052231 & 0.000398 & 0.001376 & 0.000012 & 0.282349 & 0.000013 & -12.3 & 1941 \\
\hline MJ16-06 & 163 & 0.040939 & 0.000383 & 0.001165 & 0.000011 & 0.282314 & 0.000015 & -13.2 & 2007 \\
\hline MJ16-07 & 130 & 0.029114 & 0.001145 & 0.000752 & 0.000028 & 0.282387 & 0.000012 & -11.3 & 1864 \\
\hline
\end{tabular}




\begin{tabular}{|c|c|c|c|c|c|c|c|c|c|}
\hline Analysis & Age (Ma) & ${ }^{176} \mathbf{Y b} /{ }^{177} \mathbf{H f}$ & $2 \sigma$ & ${ }^{176} \mathrm{Lu} /{ }^{177} \mathrm{Hf}$ & $2 \sigma$ & ${ }^{176} \mathrm{Hf} /{ }^{177} \mathrm{Hf}$ & $2 \sigma$ & $\varepsilon_{\mathrm{Hf}}(\mathrm{t})$ & $\mathrm{T}_{\mathrm{DM} 2}$ \\
\hline \multicolumn{10}{|c|}{ Min River } \\
\hline MJ16-08 & 1666 & 0.017543 & 0.000139 & 0.000429 & 0.000002 & 0.281454 & 0.000016 & -10.0 & 2972 \\
\hline MJ16-10 & 436 & 0.043012 & 0.001129 & 0.001278 & 0.000039 & 0.282311 & 0.000021 & -7.4 & 1859 \\
\hline MJ16-12 & 1831 & 0.021971 & 0.000055 & 0.000530 & 0.000001 & 0.281531 & 0.000017 & -3.7 & 2713 \\
\hline MJ16-13 & 2695 & 0.012786 & 0.000104 & 0.000303 & 0.000001 & 0.280876 & 0.000016 & -6.8 & 3576 \\
\hline MJ16-14 & 1884 & 0.023166 & 0.000953 & 0.000594 & 0.000021 & 0.281452 & 0.000017 & -5.4 & 2858 \\
\hline MJ16-15 & 145 & 0.037809 & 0.000076 & 0.000992 & 0.000002 & 0.282249 & 0.000025 & -15.8 & 2160 \\
\hline MJ16-16 & 1776 & 0.021916 & 0.000547 & 0.000629 & 0.000020 & 0.281218 & 0.000016 & -16.2 & 3430 \\
\hline MJ16-17 & 2191 & 0.038535 & 0.000490 & 0.000933 & 0.000010 & 0.281492 & 0.000016 & 2.5 & 2615 \\
\hline MJ16-18 & 1810 & 0.012297 & 0.000772 & 0.000330 & 0.000022 & 0.281524 & 0.000016 & -4.2 & 2727 \\
\hline MJ16-19 & 875 & 0.029169 & 0.000491 & 0.000796 & 0.000011 & 0.282272 & 0.000016 & 1.0 & 1677 \\
\hline MJ16-20 & 862 & 0.039053 & 0.000779 & 0.001041 & 0.000018 & 0.282296 & 0.000016 & 1.4 & 1641 \\
\hline MJ16-21 & 1845 & 0.028006 & 0.000165 & 0.000674 & 0.000004 & 0.281465 & 0.000018 & -5.9 & 2860 \\
\hline MJ16-22 & 106 & 0.028127 & 0.000333 & 0.000756 & 0.000010 & 0.282590 & 0.000022 & -4.6 & 1428 \\
\hline MJ16-23 & 418 & 0.043351 & 0.000778 & 0.001090 & 0.000018 & 0.282294 & 0.000017 & -8.4 & 1905 \\
\hline MJ16-24 & 1823 & 0.032185 & 0.000131 & 0.000752 & 0.000003 & 0.281506 & 0.000019 & -5.0 & 2788 \\
\hline MJ16-25 & 116 & 0.044748 & 0.001381 & 0.001105 & 0.000030 & 0.282460 & 0.000020 & -9.0 & 1712 \\
\hline MJ16-26 & 388 & 0.016626 & 0.000072 & 0.000369 & 0.000002 & 0.282305 & 0.000016 & -8.4 & 1885 \\
\hline MJ16-28 & 2656 & 0.021292 & 0.000093 & 0.000537 & 0.000002 & 0.280919 & 0.000013 & -6.6 & 3534 \\
\hline MJ16-29 & 1683 & 0.068076 & 0.000390 & 0.001733 & 0.000011 & 0.281878 & 0.000018 & 3.9 & 2129 \\
\hline MJ16-30 & 156 & 0.032325 & 0.000331 & 0.000838 & 0.000010 & 0.282348 & 0.000017 & -12.1 & 1935 \\
\hline MJ16-31 & 224 & 0.031720 & 0.000389 & 0.000782 & 0.000010 & 0.282262 & 0.000022 & -13.6 & 2085 \\
\hline MJ16-32 & 2278 & 0.022973 & 0.000553 & 0.000650 & 0.000017 & 0.281286 & 0.000017 & -2.4 & 2983 \\
\hline MJ16-33 & 216 & 0.022117 & 0.000310 & 0.000585 & 0.000008 & 0.282419 & 0.000023 & -8.2 & 1740 \\
\hline MJ16-34 & 427 & 0.023062 & 0.000232 & 0.000583 & 0.000007 & 0.282291 & 0.000019 & -8.1 & 1898 \\
\hline MJ16-35 & 431 & 0.014683 & 0.000444 & 0.000390 & 0.000011 & 0.282359 & 0.000020 & -5.6 & 1741 \\
\hline MJ16-36 & 419 & 0.030850 & 0.000901 & 0.000771 & 0.000022 & 0.282332 & 0.000019 & -6.9 & 1814 \\
\hline MJ16-37 & 469 & 0.035972 & 0.000512 & 0.000895 & 0.000013 & 0.282496 & 0.000017 & -0.1 & 1423 \\
\hline MJ16-38 & 2209 & 0.021256 & 0.000326 & 0.000524 & 0.000009 & 0.281397 & 0.000021 & 0.2 & 2773 \\
\hline MJ16-39 & 1855 & 0.061979 & 0.001543 & 0.001475 & 0.000037 & 0.281609 & 0.000020 & -1.6 & 2601 \\
\hline MJ16-40 & 964 & 0.039162 & 0.000094 & 0.000932 & 0.000005 & 0.281963 & 0.000019 & -8.1 & 2311 \\
\hline MJ16-41 & 222 & 0.029683 & 0.000238 & 0.000810 & 0.000005 & 0.282081 & 0.000020 & -20.1 & 2483 \\
\hline MJ16-42 & 1957 & 0.020695 & 0.000697 & 0.000532 & 0.000020 & 0.281349 & 0.000017 & -7.3 & 3031 \\
\hline MJ16-43 & 232 & 0.035693 & 0.001447 & 0.000901 & 0.000033 & 0.282509 & 0.000021 & -4.8 & 1535 \\
\hline MJ16-44 & 224 & 0.023299 & 0.000119 & 0.000585 & 0.000004 & 0.282484 & 0.000021 & -5.8 & 1591 \\
\hline MJ16-45 & 459 & 0.036926 & 0.000343 & 0.000966 & 0.000007 & 0.282583 & 0.000022 & 2.8 & 1235 \\
\hline MJ16-46 & 1821 & 0.021953 & 0.000292 & 0.000532 & 0.000007 & 0.281573 & 0.000018 & -2.4 & 2627 \\
\hline MJ16-47 & 2742 & 0.030218 & 0.000312 & 0.000841 & 0.000008 & 0.281049 & 0.000022 & -0.5 & 3236 \\
\hline MJ16-48 & 97 & 0.043706 & 0.000368 & 0.001082 & 0.000008 & 0.282493 & 0.000020 & -8.2 & 1650 \\
\hline MJ16-50 & 227 & 0.034669 & 0.000253 & 0.000845 & 0.000005 & 0.282433 & 0.000019 & -7.5 & 1706 \\
\hline MJ16-51 & 1881 & 0.022506 & 0.000644 & 0.000558 & 0.000014 & 0.281465 & 0.000018 & -4.9 & 2827 \\
\hline MJ16-52 & 161 & 0.085637 & 0.001527 & 0.002044 & 0.000034 & 0.282405 & 0.000021 & -10.1 & 1813 \\
\hline MJ16-53 & 1787 & 0.018956 & 0.000435 & 0.000467 & 0.000012 & 0.281417 & 0.000017 & -8.6 & 2982 \\
\hline MJ16-54 & 2504 & 0.031714 & 0.000409 & 0.000793 & 0.000009 & 0.281273 & 0.000018 & 2.1 & 2890 \\
\hline MJ16-55 & 1873 & 0.049442 & 0.000409 & 0.001192 & 0.000012 & 0.281671 & 0.000022 & 1.4 & 2434 \\
\hline MJ16-56 & 1892 & 0.013517 & 0.000457 & 0.000326 & 0.000008 & 0.281353 & 0.000018 & -8.4 & 3047 \\
\hline
\end{tabular}




\begin{tabular}{|c|c|c|c|c|c|c|c|c|c|}
\hline Analysis & Age (Ma) & ${ }^{176} \mathbf{Y b} /{ }^{177} \mathbf{H f}$ & $2 \sigma$ & ${ }^{176} \mathrm{Lu} /{ }^{177} \mathbf{H f}$ & $2 \sigma$ & ${ }^{176} \mathbf{H f} /{ }^{177} \mathbf{H f}$ & $2 \sigma$ & $\varepsilon_{\mathrm{Hf}}(\mathrm{t})$ & $\mathbf{T}_{\mathrm{DM} 2}$ \\
\hline \multicolumn{10}{|c|}{ Min River } \\
\hline MJ16-57 & 233 & 0.021324 & 0.000214 & 0.000537 & 0.000003 & 0.282249 & 0.000022 & -13.9 & 2104 \\
\hline MJ16-58 & 438 & 0.041841 & 0.000557 & 0.001039 & 0.000012 & 0.282359 & 0.000022 & -5.6 & 1749 \\
\hline MJ16-59 & 2441 & 0.028546 & 0.000108 & 0.000757 & 0.000004 & 0.281291 & 0.000023 & 1.3 & 2884 \\
\hline MJ16-60 & 133 & 0.053976 & 0.000829 & 0.001318 & 0.000022 & 0.282327 & 0.000021 & -13.4 & 1997 \\
\hline MJ16-61 & 421 & 0.073973 & 0.002135 & 0.001884 & 0.000048 & 0.282361 & 0.000021 & -6.1 & 1768 \\
\hline MJ16-62 & 109 & 0.070645 & 0.001992 & 0.001891 & 0.000057 & 0.282542 & 0.000022 & -6.3 & 1536 \\
\hline MJ16-63 & 953 & 0.116861 & 0.001329 & 0.002770 & 0.000031 & 0.282304 & 0.000022 & 2.6 & 1639 \\
\hline MJ16-64 & 1793 & 0.037020 & 0.000535 & 0.000897 & 0.000010 & 0.281396 & 0.000025 & -9.8 & 3057 \\
\hline MJ16-65 & 407 & 0.083487 & 0.000570 & 0.002052 & 0.000013 & 0.282324 & 0.000021 & -7.8 & 1861 \\
\hline MJ16-66 & 1868 & 0.048718 & 0.000164 & 0.001190 & 0.000005 & 0.281525 & 0.000018 & -3.9 & 2755 \\
\hline MJ16-67 & 145 & 0.049241 & 0.000421 & 0.001232 & 0.000010 & 0.282238 & 0.000020 & -16.2 & 2186 \\
\hline MJ16-68 & 2713 & 0.035476 & 0.000239 & 0.000866 & 0.000003 & 0.280955 & 0.000021 & -4.6 & 3459 \\
\hline MJ16-69 & 227 & 0.035191 & 0.000210 & 0.000859 & 0.000006 & 0.282471 & 0.000020 & -6.2 & 1621 \\
\hline MJ16-71 & 1862 & 0.043034 & 0.000661 & 0.001039 & 0.000017 & 0.281714 & 0.000024 & 2.9 & 2334 \\
\hline MJ16-72 & 1827 & 0.008367 & 0.000342 & 0.000191 & 0.000008 & 0.281476 & 0.000020 & -5.3 & 2809 \\
\hline MJ16-73 & 1878 & 0.046839 & 0.001680 & 0.001140 & 0.000041 & 0.281361 & 0.000018 & -9.4 & 3101 \\
\hline MJ16-74 & 407 & 0.044161 & 0.000393 & 0.001103 & 0.000008 & 0.282320 & 0.000019 & -7.7 & 1854 \\
\hline MJ16-75 & 2525 & 0.013630 & 0.000188 & 0.000328 & 0.000004 & 0.281361 & 0.000022 & 6.5 & 2638 \\
\hline MJ16-76 & 1858 & 0.025367 & 0.000280 & 0.000625 & 0.000005 & 0.281508 & 0.000017 & -4.0 & 2754 \\
\hline MJ16-77 & 1344 & 0.051744 & 0.000066 & 0.001267 & 0.000001 & 0.281546 & 0.000016 & -14.8 & 3015 \\
\hline MJ16-78 & 2531 & 0.041769 & 0.000821 & 0.001259 & 0.000022 & 0.281307 & 0.000019 & 3.1 & 2848 \\
\hline MJ16-80 & 105 & 0.028005 & 0.000785 & 0.000712 & 0.000017 & 0.282447 & 0.000020 & -9.7 & 1745 \\
\hline MJ16-81 & 1872 & 0.036331 & 0.000216 & 0.000860 & 0.000004 & 0.281464 & 0.000020 & -5.6 & 2860 \\
\hline MJ16-82 & 97 & 0.081189 & 0.002803 & 0.002072 & 0.000070 & 0.282617 & 0.000024 & -3.9 & 1378 \\
\hline MJ16-83 & 826 & 0.041500 & 0.000186 & 0.001203 & 0.000007 & 0.282133 & 0.000023 & -5.3 & 2027 \\
\hline MJ16-84 & 445 & 0.059479 & 0.001129 & 0.001693 & 0.000034 & 0.282372 & 0.000027 & -5.2 & 1727 \\
\hline MJ16-85 & 223 & 0.024094 & 0.000393 & 0.000748 & 0.000010 & 0.282479 & 0.000017 & -6.0 & 1604 \\
\hline MJ16-86 & 1510 & 0.062850 & 0.003244 & 0.001527 & 0.000079 & 0.281574 & 0.000026 & -10.4 & 2875 \\
\hline MJ16-87 & 2299 & 0.032298 & 0.000477 & 0.000878 & 0.000011 & 0.281350 & 0.000019 & 0.0 & 2854 \\
\hline MJ16-88 & 1879 & 0.018216 & 0.000411 & 0.000450 & 0.000009 & 0.281432 & 0.000022 & -6.0 & 2894 \\
\hline MJ16-89 & 2183 & 0.031744 & 0.001335 & 0.000798 & 0.000027 & 0.281157 & 0.000026 & -9.4 & 3332 \\
\hline MJ16-90 & 226 & 0.020614 & 0.000089 & 0.000525 & 0.000001 & 0.282403 & 0.000025 & -8.6 & 1768 \\
\hline MJ16-91 & 1564 & 0.034472 & 0.000263 & 0.000848 & 0.000009 & 0.281515 & 0.000023 & -10.6 & 2929 \\
\hline MJ16-92 & 363 & 0.035693 & 0.001447 & 0.000901 & 0.000033 & 0.282509 & 0.000021 & -1.9 & 1458 \\
\hline MJ16-93 & 1871 & 0.023651 & 0.000134 & 0.000585 & 0.000002 & 0.281405 & 0.000025 & -7.3 & 2967 \\
\hline MJ16-94 & 2067 & 0.016983 & 0.000204 & 0.000442 & 0.000006 & 0.281322 & 0.000021 & -5.6 & 3016 \\
\hline MJ16-95 & 233 & 0.019926 & 0.000185 & 0.000507 & 0.000005 & 0.282332 & 0.000030 & -10.9 & 1923 \\
\hline MJ16-96 & 454 & 0.071255 & 0.006289 & 0.001910 & 0.000157 & 0.282362 & 0.000027 & -5.4 & 1748 \\
\hline MJ16-97 & 945 & 0.022146 & 0.000460 & 0.000545 & 0.000012 & 0.281919 & 0.000027 & -9.8 & 2402 \\
\hline \multicolumn{10}{|c|}{ JiulongRiver } \\
\hline JL01-01 & 239 & 0.048273 & 0.000278 & 0.001602 & 0.000013 & 0.282570 & 0.000011 & -2.5 & 1401 \\
\hline JL01-02 & 2577 & 0.008652 & 0.000191 & 0.000277 & 0.000006 & 0.280902 & 0.000011 & -8.6 & 3591 \\
\hline JL01-03 & 138 & 0.042849 & 0.000148 & 0.001490 & 0.000011 & 0.282464 & 0.000010 & -8.4 & 1692 \\
\hline JL01-04 & 116 & 0.021981 & 0.000159 & 0.000796 & 0.000004 & 0.282680 & 0.000011 & -1.2 & 1220 \\
\hline JL01-05 & 932 & 0.033752 & 0.000472 & 0.001002 & 0.000016 & 0.281779 & 0.000010 & -15.4 & 2733 \\
\hline
\end{tabular}




\begin{tabular}{|c|c|c|c|c|c|c|c|c|c|}
\hline Analysis & Age (Ma) & ${ }^{176} \mathbf{Y b} /{ }^{177} \mathbf{H f}$ & $2 \sigma$ & ${ }^{176} \mathbf{L u} /{ }^{177} \mathbf{H f}$ & $2 \sigma$ & ${ }^{176} \mathrm{Hf} /{ }^{177} \mathrm{Hf}$ & $2 \sigma$ & $\varepsilon_{\mathrm{Hf}}(\mathrm{t})$ & $\mathrm{T}_{\mathrm{DM} 2}$ \\
\hline \multicolumn{10}{|c|}{ JiulongRiver } \\
\hline JL01-06 & 165 & 0.063960 & 0.001306 & 0.001862 & 0.000038 & 0.282551 & 0.000011 & -4.8 & 1488 \\
\hline JL01-07 & 107 & 0.018282 & 0.000282 & 0.000562 & 0.000010 & 0.282682 & 0.000011 & -1.3 & 1221 \\
\hline JL01-08 & 253 & 0.034910 & 0.000271 & 0.001190 & 0.000014 & 0.282419 & 0.000010 & -7.5 & 1724 \\
\hline JL01-10 & 211 & 0.070666 & 0.000631 & 0.002266 & 0.000020 & 0.282488 & 0.000013 & -6.1 & 1604 \\
\hline JL01-11 & 250 & 0.026931 & 0.000164 & 0.000799 & 0.000003 & 0.282413 & 0.000011 & -7.7 & 1735 \\
\hline JL01-12 & 165 & 0.027485 & 0.000090 & 0.000798 & 0.000002 & 0.282402 & 0.000010 & -10.0 & 1809 \\
\hline JL01-13 & 163 & 0.040173 & 0.000542 & 0.001306 & 0.000016 & 0.282559 & 0.000012 & -4.5 & 1466 \\
\hline JL01-14 & 207 & 0.042849 & 0.000210 & 0.001429 & 0.000006 & 0.282530 & 0.000016 & -4.6 & 1506 \\
\hline JL01-15 & 155 & 0.039230 & 0.001608 & 0.001236 & 0.000050 & 0.282687 & 0.000011 & -0.1 & 1184 \\
\hline JL01-16 & 1474 & 0.029702 & 0.001294 & 0.000932 & 0.000044 & 0.281655 & 0.000013 & -7.7 & 2683 \\
\hline JL01-17 & 153 & 0.050612 & 0.001376 & 0.001825 & 0.000053 & 0.282524 & 0.000019 & -6.0 & 1552 \\
\hline JL01-18 & 238 & 0.040485 & 0.000286 & 0.001199 & 0.000005 & 0.282394 & 0.000011 & -8.7 & 1788 \\
\hline JL01-19 & 125 & 0.033270 & 0.000808 & 0.001124 & 0.000027 & 0.282567 & 0.000011 & -5.0 & 1468 \\
\hline JL01-20 & 110 & 0.034736 & 0.000613 & 0.001203 & 0.000018 & 0.282678 & 0.000010 & -1.4 & 1231 \\
\hline JL01-21 & 158 & 0.020037 & 0.000474 & 0.000614 & 0.000011 & 0.282741 & 0.000013 & 1.9 & 1058 \\
\hline JL01-22 & 248 & 0.088196 & 0.001200 & 0.002452 & 0.000027 & 0.282405 & 0.000011 & -8.3 & 1772 \\
\hline JL01-23 & 275 & 0.031200 & 0.001654 & 0.001000 & 0.000048 & 0.282641 & 0.000012 & 0.8 & 1215 \\
\hline JL01-24 & 158 & 0.063882 & 0.000709 & 0.001921 & 0.000017 & 0.282553 & 0.000012 & -4.9 & 1485 \\
\hline JL01-25 & 1588 & 0.045133 & 0.000548 & 0.001287 & 0.000019 & 0.281572 & 0.000011 & -8.5 & 2820 \\
\hline JL01-26 & 103 & 0.034546 & 0.000366 & 0.001092 & 0.000014 & 0.282633 & 0.000012 & -3.2 & 1335 \\
\hline JL01-27 & 197 & 0.069701 & 0.000589 & 0.001876 & 0.000011 & 0.282842 & 0.000011 & 6.1 & 818 \\
\hline JL01-28 & 251 & 0.036758 & 0.000197 & 0.001113 & 0.000006 & 0.282422 & 0.000010 & -7.4 & 1717 \\
\hline JL01-29 & 148 & 0.114050 & 0.001148 & 0.003328 & 0.000018 & 0.282614 & 0.000013 & -3.1 & 1363 \\
\hline JL01-30 & 2252 & 0.015607 & 0.000145 & 0.000477 & 0.000003 & 0.281207 & 0.000010 & -5.5 & 3154 \\
\hline JL01-31 & 267 & 0.053562 & 0.000300 & 0.001793 & 0.000008 & 0.282392 & 0.000008 & -8.3 & 1783 \\
\hline JL01-33 & 244 & 0.028748 & 0.000166 & 0.000847 & 0.000006 & 0.282404 & 0.000010 & -8.2 & 1760 \\
\hline JL01-35 & 118 & 0.025736 & 0.000485 & 0.000829 & 0.000018 & 0.282713 & 0.000013 & 0.0 & 1145 \\
\hline JL01-37 & 1642 & 0.047665 & 0.000623 & 0.001355 & 0.000011 & 0.281499 & 0.000011 & -10.0 & 2953 \\
\hline JL01-38 & 474 & 0.038773 & 0.000828 & 0.001261 & 0.000028 & 0.282142 & 0.000012 & -12.6 & 2210 \\
\hline JL01-40 & 141 & 0.031526 & 0.000126 & 0.001013 & 0.000001 & 0.282515 & 0.000012 & -6.5 & 1575 \\
\hline JL01-41 & 661 & 0.002901 & 0.000095 & 0.000083 & 0.000003 & 0.282010 & 0.000010 & -12.7 & 2361 \\
\hline JL01-42 & 147 & 0.034211 & 0.000365 & 0.001130 & 0.000011 & 0.282575 & 0.000012 & -4.3 & 1438 \\
\hline JL01-43 & 2241 & 0.017393 & 0.000221 & 0.000495 & 0.000004 & 0.280926 & 0.000012 & -15.8 & 3766 \\
\hline JL01-44 & 134 & 0.039526 & 0.000767 & 0.001290 & 0.000025 & 0.282557 & 0.000013 & -5.2 & 1486 \\
\hline JL01-45 & 254 & 0.031299 & 0.000884 & 0.000964 & 0.000028 & 0.282461 & 0.000014 & -6.0 & 1628 \\
\hline JL01-46 & 162 & 0.021503 & 0.000477 & 0.000621 & 0.000011 & 0.282414 & 0.000012 & -9.6 & 1783 \\
\hline JL01-47 & 1636 & 0.029979 & 0.000076 & 0.000826 & 0.000005 & 0.281517 & 0.000010 & -8.9 & 2881 \\
\hline JL01-48 & 275 & 0.032616 & 0.000353 & 0.001058 & 0.000008 & 0.282760 & 0.000011 & 5.0 & 949 \\
\hline JL01-49 & 160 & 0.038752 & 0.000091 & 0.001189 & 0.000004 & 0.282349 & 0.000012 & -12.0 & 1934 \\
\hline JL01-50 & 109 & 0.059846 & 0.001314 & 0.001936 & 0.000054 & 0.282657 & 0.000017 & -2.2 & 1281 \\
\hline JL01-51 & 108 & 0.018644 & 0.000492 & 0.000580 & 0.000020 & 0.282724 & 0.000014 & 0.2 & 1126 \\
\hline JL01-52 & 235 & 0.027527 & 0.000203 & 0.000808 & 0.000004 & 0.282408 & 0.000011 & -8.2 & 1755 \\
\hline JL01-53 & 119 & 0.045767 & 0.002293 & 0.001291 & 0.000057 & 0.282458 & 0.000013 & -9.0 & 1716 \\
\hline JL01-54 & 110 & 0.045233 & 0.001101 & 0.001306 & 0.000047 & 0.282775 & 0.000018 & 2.0 & 1013 \\
\hline JL01-55 & 103 & 0.038154 & 0.000239 & 0.001211 & 0.000009 & 0.282536 & 0.000011 & -6.6 & 1550 \\
\hline
\end{tabular}




\begin{tabular}{|c|c|c|c|c|c|c|c|c|c|}
\hline Analysis & Age (Ma) & ${ }^{176} \mathbf{Y b} /{ }^{177} \mathbf{H f}$ & $2 \sigma$ & ${ }^{176} \mathbf{L u} /{ }^{177} \mathbf{H f}$ & $2 \sigma$ & ${ }^{176} \mathbf{H f} /{ }^{177} \mathbf{H f}$ & $2 \sigma$ & $\varepsilon_{\mathrm{Hf}}(\mathrm{t})$ & $\mathbf{T}_{\mathrm{DM} 2}$ \\
\hline \multicolumn{10}{|c|}{ JiulongRiver } \\
\hline JL01-56 & 146 & 0.058291 & 0.000557 & 0.001939 & 0.000025 & 0.282500 & 0.000010 & -7.0 & 1610 \\
\hline JL01-59 & 164 & 0.049661 & 0.000749 & 0.001547 & 0.000023 & 0.282463 & 0.000011 & -7.9 & 1680 \\
\hline JL01-60 & 241 & 0.028716 & 0.000337 & 0.000820 & 0.000011 & 0.282419 & 0.000010 & -7.7 & 1728 \\
\hline JL01-61 & 101 & 0.050997 & 0.000783 & 0.001477 & 0.000021 & 0.282660 & 0.000011 & -2.3 & 1277 \\
\hline JL01-62 & 110 & 0.020147 & 0.000325 & 0.000593 & 0.000007 & 0.282693 & 0.000010 & -0.9 & 1194 \\
\hline JL01-63 & 158 & 0.061347 & 0.000756 & 0.001936 & 0.000022 & 0.282529 & 0.000012 & -5.8 & 1540 \\
\hline JL01-64 & 1834 & 0.027224 & 0.000119 & 0.000775 & 0.000003 & 0.281444 & 0.000010 & -7.0 & 2918 \\
\hline JL01-65 & 149 & 0.055698 & 0.001164 & 0.001752 & 0.000023 & 0.282684 & 0.000011 & -0.4 & 1197 \\
\hline JL01-66 & 149 & 0.035816 & 0.000461 & 0.001013 & 0.000011 & 0.282579 & 0.000011 & -4.1 & 1428 \\
\hline JL01-67 & 162 & 0.046018 & 0.000576 & 0.001430 & 0.000018 & 0.282384 & 0.000012 & -10.7 & 1856 \\
\hline JL01-68 & 240 & 0.021824 & 0.000119 & 0.000691 & 0.000006 & 0.282683 & 0.000010 & 1.6 & 1138 \\
\hline JL01-69 & 403 & 0.051759 & 0.001092 & 0.001520 & 0.000036 & 0.282348 & 0.000014 & -6.9 & 1800 \\
\hline JL01-70 & 143 & 0.039916 & 0.000549 & 0.001272 & 0.000022 & 0.282568 & 0.000017 & -4.6 & 1456 \\
\hline JL01-71 & 137 & 0.056865 & 0.000408 & 0.001957 & 0.000008 & 0.282541 & 0.000012 & -5.8 & 1525 \\
\hline JL01-72 & 106 & 0.015529 & 0.000146 & 0.000456 & 0.000002 & 0.282405 & 0.000012 & -11.1 & 1836 \\
\hline JL01-73 & 235 & 0.023750 & 0.000476 & 0.000679 & 0.000011 & 0.282447 & 0.000011 & -6.9 & 1669 \\
\hline JL01-74 & 228 & 0.039647 & 0.000352 & 0.001146 & 0.000014 & 0.282387 & 0.000013 & -9.2 & 1809 \\
\hline JL01-75 & 103 & 0.015642 & 0.000123 & 0.000461 & 0.000006 & 0.282658 & 0.000012 & -2.2 & 1275 \\
\hline JL01-76 & 152 & 0.038625 & 0.000275 & 0.001191 & 0.000010 & 0.282540 & 0.000011 & -5.4 & 1514 \\
\hline JL01-77 & 148 & 0.051151 & 0.000824 & 0.001645 & 0.000037 & 0.282516 & 0.000011 & -6.4 & 1572 \\
\hline JL01-78 & 800 & 0.017803 & 0.000619 & 0.000510 & 0.000012 & 0.282325 & 0.000011 & 1.4 & 1594 \\
\hline JL01-79 & 1675 & 0.014747 & 0.000274 & 0.000506 & 0.000006 & 0.281383 & 0.000011 & -12.5 & 3127 \\
\hline JL01-80 & 150 & 0.032358 & 0.000185 & 0.001037 & 0.000008 & 0.282589 & 0.000012 & -3.7 & 1405 \\
\hline
\end{tabular}

